Florida International University FIU Digital Commons

8-6-2002

\title{
An examination of the possible consolidation of African American political power through selective migration
}

Brian Dean Abramson

Florida International University

DOI: $10.25148 /$ etd.FI13101513

Follow this and additional works at: https://digitalcommons.fiu.edu/etd

Part of the International and Area Studies Commons, and the Race and Ethnicity Commons

\section{Recommended Citation}

Abramson, Brian Dean, "An examination of the possible consolidation of African American political power through selective migration" (2002). FIU Electronic Theses and Dissertations. 1082.

https://digitalcommons.fiu.edu/etd/1082 
FLORIDA INTERNATIONAL UNIVERSITY

Miami, Florida

\section{AN EXAMINATION OF THE POSSIBLE CONSOLIDATION \\ OF AFRICAN AMERICAN POLITICAL POWER \\ THROUGH SELECTIVE MIGRATION}

A thesis submitted in partial fulfillment of the

requirements for the degree of

MASTER OF ARTS

in

COMPARATIVE SOCIOLOGY

by

Brian Dean Abramson 
To: Dean Arthur W. Herriott

College of Arts and Sciences

This thesis, written by Brian Dean Abramson, and entitled An Examination of the Possible Consolidation of African American Political Power Through Selective Migration, having been approved in respect to style and intellectual content, is referred to you for judgment.

We have read this thesis and recommend that it beapproved.

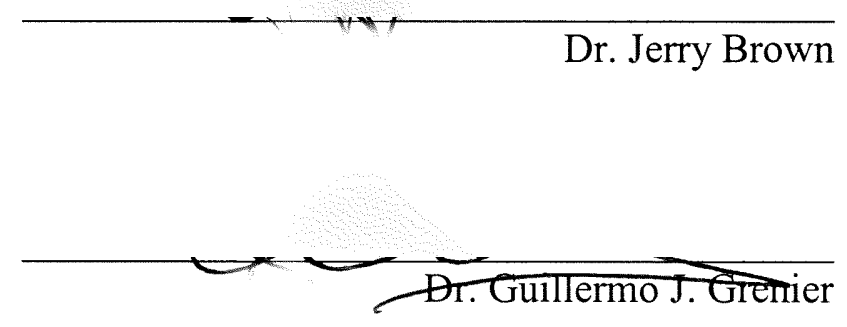

Dr. Abraham D. Lavender, Major Professor

Date of Defense: August 6, 2002

The thesis of Brian Dean Abramson is approved.

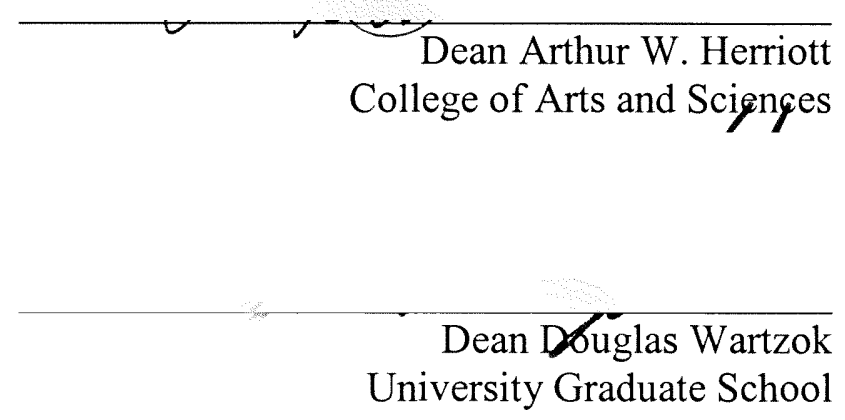

Florida International University, 2002 
(C) Copyright 2002 by Brian Dean Abramson

All rights reserved. 


\section{DEDICATION}

I dedicate this thesis to Sara. 


\section{ACKNOWLEDGMENTS}

I wish to thank the members of my committee: Dr. Jerry Brown; Dr. Guillermo Grenier; and most of all, my major professor, Dr. Abraham D. Lavender, for believing in the power of an idea, and for understanding that even an idea that suggests the most unlikely outcome may still be worth examining. I would also like to thank my lovely wife, Sara, whose very presence has lent a constant air of joy to the most challenging tasks; and my parents, for their support throughout the duration of this project. 


\author{
ABSTRACT OF THE THESIS \\ AN EXAMINATION OF THE POSSIBLE CONSOLIDATION \\ OF AFRICAN AMERICAN POLITICAL POWER \\ THROUGH SELECTIVE MIGRATION \\ by \\ Brian Dean Abramson \\ Florida International University, 2002 \\ Miami, Florida \\ Professor Abraham D. Lavender, Major Professor
}

This study examined whether African Americans could consolidate political power through a migration into a specific state or set of states in sufficient numbers to establish a voting majority within that state. In order to examine the feasibility and efficacy of this strategy, a variety of factors were reviewed, including the historical context leading to the current situation; the political benefits to be derived from the control of a state; and the population and migration patterns of African Americans. The results indicated that this strategy could succeed in providing significant substantive and symbolic political benefits to the African American community, but could also have some negative repercussions. 


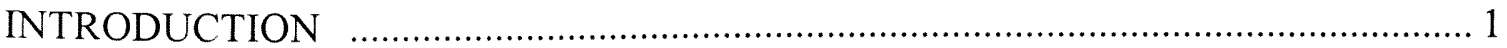

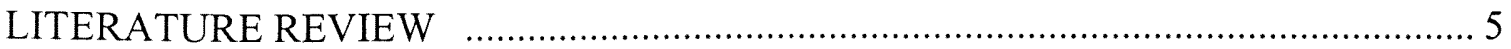

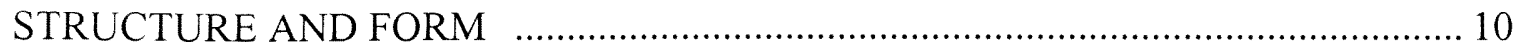

CHAPTER I. The Development of the Modern Dilemma …....................................... 13

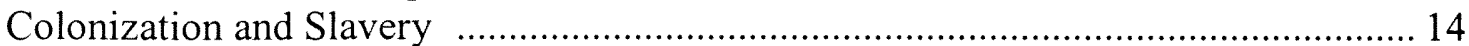

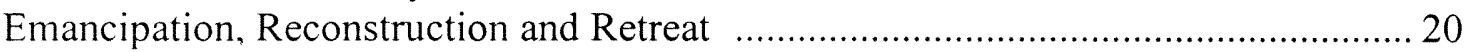

The Political Re-Awakening of African Americans ..................................................... 31

CHAPTER II. Success and Failure in the Continuing Struggle .................................. 38

Persistent Ethnocentrism in Election Behavior ......................................................... 39

Gains Earned and Lost in Recent Decades …............................................................ 47

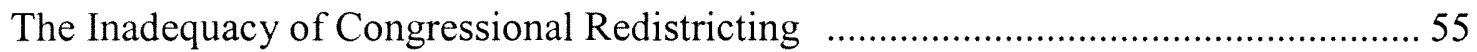

Relative Political Power in Elected Offices ........................................................... 58

Governmental Elements Derived From the State as a Political Unit ..........................63

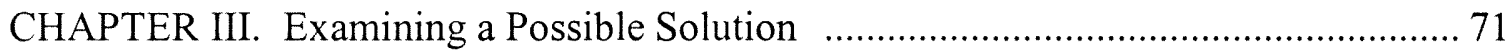

Majority and Minority Group Strategies ……….................................................... 72

Other Cases of State Control by Minority Groups …….............................................. 76

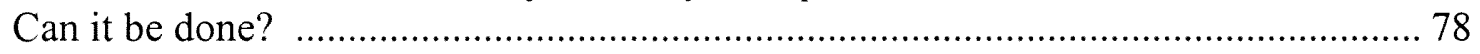

Calculating the Differential by State ……............................................................. 80

How Can a Group Best Achieve a Voting Majority In a State? ................................ 98

Incorporating Existing Patterns of Migration and Population Growth ..................... 100

An Examination of Specific States …............................................................. 111

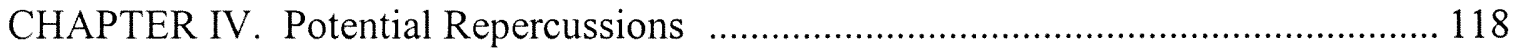

Relations Between a Black Majority and a White Minority ................................... 119

Potential Effects on Party Loyalty and Affiliation ................................................ 129

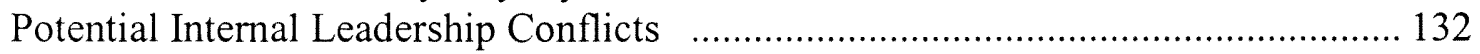

Pressures of Governing Under the National Microscope ….................................... 134

The Effect on the Nation as a Whole .................................................................... 136

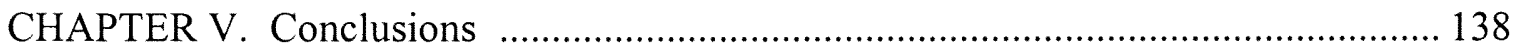

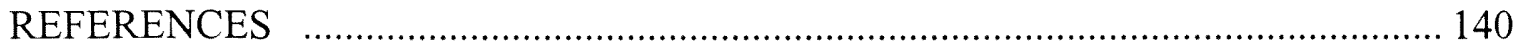

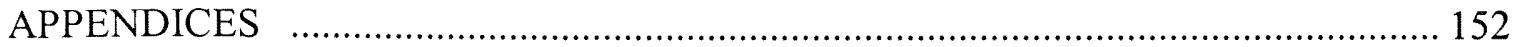


I. Descriptive Statistics for Independent Variables

II. Logistic Regression predicting willingness of Whites

to vote for a Black candidate for President nominated by their own party

III. Representation of Black Elected Officials compared with Black proportion of state population for the top 20 states with the highest Black proportions

IV. Calculation of Differentials (number of Blacks who would need to move into a state to establish a Black majority within that state) ranked from lowest to highest

V. Percentage of Blacks living outside a state required 93 to move into that state in order to achieve a Black majority, ranked from lowest to highest

VI. Interstate Mobility by Race in randomly selected years

VII. Willingness of GSS respondents to move to another state in order to 'improve work or living conditions'

VIII. Black population by decade from 1970 to 2000 103 ranked by rate of increase in Black population from 1990 to 2000 , from highest to lowest.

IX. Black proportion by decade from 1970 to 2000 105 ranked by rate of increase in Black proportion from 1990 to 2000 , from highest to lowest.

X. First ten states to reach a majority of persons claiming 108 any Black heritage at 1990-2000 rate of growth

XI. First ten states to reach a majority of persons claiming 108 only Black heritage at 1990-2000 rate of growth

XII. Percentage increase in state population that would occur 112 in the process of achieving a Black majority (assuming that no Whites left the state), ranked from lowest to highest. 


\section{INTRODUCTION}

Could African Americans enhance their political power through a movement designed to accelerate the creation of a Black majority in a targeted state or group of states? Americans of African descent clearly suffer from a variety of disadvantages compared to the White majority in this country, including a distinct deficiency of social, economic, and political capital (Barker et al, 1999; Cancio et al, 1996; Feagin and Sikes, 1994; Hughes and Thomas, 1998). In the political arena, Blacks are proportionally under-represented in all branches and levels of government, including municipal bodies, state legislatures, and the United States Congress (Bositas, 2000; Grofman et al, 1992; Reeves, 1997). In the entire history of this nation, only two Blacks have ever been elected to the powerful position of United States Senator, and only one has ever been elected as a state governor (Kiely, 2002). This is not surprising, given the basic ethnocentric tendency of individual voters, who feel more comfortable supporting candidates of their own ethnicity. For Black communities in America, this tendency is exacerbated by the fact that no state has been more than $36 \%$ Black since the passage of the Voting Rights Act of 1965 dismantled the mechanisms used in many states to deprive Blacks of the ability to exercise their right to vote.

Research suggests that White voters in a given area become less likely to vote for Black candidates as the Black proportion of the population in that area increases, indicating that White voters experience a compelling sense of ethnic economic and political threat (Grofman et al, 1992; Reeves, 1997; Taylor, 1998, 2000). Recent efforts to enhance Black political representation at the national level have recognized the historic 
reluctance of White voters to vote for Black candidates, and have therefore concentrated on creating majority-Black Congressional districts. Such districts have successfully allowed Black communities seeking both symbolic and substantive representation to overcome the lack of support from White voters (Canon, 1999; Clayton, 2000; Grofman et al, 1992; Reeves, 1997; Swain, 1995). Despite the success of these efforts in increasing political representation, they fall far short of providing representation at higher levels of government. Furthermore, the maintenance of such districts requires a constant struggle in the various state legislatures, which control the redistricting process, and in the courts. This process has proven to be expensive, time consuming, and ultimately unstable, and furthermore is susceptible to manipulation by elements of the White majority (Grofman et al, 1992; Hill, 1995; Reeves, 1997).

Moreover, some of the most powerful positions in American governmentparticularly U.S. Senate seats and state Governorships-are statewide offices, where no redistricting effort will consistently yield the kind of Black representation that would likely occur in a state with a majority-Black population. This presents a significant handicap to Black efforts to promote their concerns at the federal level, as the political power of individual Senators vastly outweighs that of individual members of the House of Representatives (Baker, 2001). At the same time, low Black proportions in many small states diminish the influence of Black voters in the elections of a significant majority of Senators, further reducing substantive representation of Blacks in the Senate. (Lee and Oppenheimer, 1999).

Blacks are able to exert only slightly greater political influence in presidential elections. Black populations in certain large Northern and Midwestern states, such as 
Michigan, Missouri, and Ohio, are large enough that when White voters are split between presidential candidates, Black voters can provide the swing vote that determines which presidential candidate will receive the state's electoral votes. Because Blacks tend to be affiliated with the Democratic Party, Black voters can have a significant influence on the distribution of delegates for the party nomination in states where they comprise a significant proportion of the Democratic party (Black and Black, 1992). In this way, Blacks may gain some substantive advantage by promoting first the nomination and then the election of the candidate that will respond to their particular concerns. Nevertheless, the uneven distribution of the Black population nationally combined with their consistent minority status reduces their impact on the actual electoral vote relative to the White majority (Black and Black, 1992; Frymer, 1999). To date, the exercise of Black influence within either political party has failed to secure the nomination of a Black presidential candidate even when Black leaders have sought this nomination. The lack of Black senators and governors also reduces the viability of possible Black candidates for higher office, as these are the positions from which presidential candidates are most frequently culled (Ardleigh, 2002; Kiely, 2002). Barker et al. (1999) assert that race remains one of the unspoken barriers to the presidency. Black electoral influence has therefore ultimately entailed swinging the votes of certain states towards one of two White candidates.

At the municipal level, Blacks have successfully captured the executive positions in several large cities, but in those cities where Blacks are not the majority group, these victories have been tenuous (Keiser, 2000b). Even in majority-Black cities, efforts to assert Black issues are hampered by the ability of the majority-White state governments 
to supersede the power of majority-Black city governments (Fleischmann, 2000; Lusane, 1994), even as White flight to suburbs outside of the city can reduce revenues and render the city more reliant on the state and on commercial interests for funding (Rich, 1991). The aforementioned imbalance in the distribution of power between large and small states also significantly affects the direction of resources towards municipal concerns, as this imbalance is skewed in favor of rural areas (Lee and Oppenheimer, 1999).

Given the problems inherent to Congressional redistricting efforts and the severe lack of representation of Blacks in the most powerful offices of government, it would seem that alternative approaches to addressing this situation are worthy of consideration. In their broad history of the African American experience, From Plantation to Ghetto, Meier and Rudwick (1976) discuss accounts of how the idea of engineering a majorityBlack state, either through a targeted migration or through alteration of existing state boundaries, has surfaced in various permutations since the decades leading up to the Civil War. Current trends in population growth already point towards the possible eventuality of a majority-Black population developing in several states before the end of the twentyfirst century (Morganthau, 1997; U.S. Census, 2001).

This thesis will examine whether accelerating this process through various means, but particularly through the migratory approach, is a viable strategy for greater political empowerment; what the likely consequences would be for the political fortunes of Blacks in America; and what effect the implementation of such a strategy might have on Black relations with the White populations of that state, the region, and the nation. 


\section{LITERATURE REVIEW}

The political status of minority groups, particularly of African Americans, has long attracted the interest of sociologists, and there is consequently a broad array of literature on this subject. This includes investigations of the necessity of redistricting efforts designed to increase Black representation in elected bodies at the municipal, state, and federal levels. The consequences of redistricting for the political process and the subsequent quality of representation by Blacks, as well as by Whites with significant Black constituencies, has been heavily researched. Grofman, Handley, and Niemi (1992) present a detailed history of the social and legal circumstances that brought about the creation of majority-Black Congressional districts, and conclude their examination with an endorsement of such districts as a method of increasing Black political representation. The argument for these districts is carried further with examinations of the negative impact that the focus on race has on Black candidates engaged in political campaigns, whether this factor is brought up by the media or by the White opponent of the minority candidate (Reeves, 1997).

A significant body of work points to the success of redistricting efforts in securing Black symbolic representation, and in increasing substantive representation through the greater political discussion of issues that are important to Black communities (Canon, 1999; Clayton, 2000). However some assert that these redistricting efforts also aid the Republican Party, which tends to oppose Black positions on these issues, by removing Black support from White candidates in adjacent districts. This, they argue, leads to the loss of liberal White representation, removing allies of Black causes (Swain, 1995) and 
reducing the representational power of African Americans by contributing to the relegation of the Democratic Party to minority status (Hill, 1995). This analysis appears to be affirmed when Black power in Congress is examined from the period after the 1992 elections, when Black candidates had realized their greatest electoral success in terms of their numbers in Congress (Lusane, 1994), compared to significantly reduced Black influence in this body after the Republican takeover following the 1994 elections (Thurber and Davidson, 1995; Swain, 1995).

Some authors specifically examine the impact of the civil rights movement on electoral politics (Andrews, 1997; Barker et al., 1999; Danigelis, 1977; Timpone, 1995), while others review the political consequences of social movement participation (Bearman and Kim, 1997; Whittier, 1997), and the structure of social movements in general (Minkoff, 1997; Olson, 1971). This leads to broader discussions of Black political influence and strategies ranging from increased Black nationalism to integration to assimilation (Abraham, 1991; Barker et al., 1999; Bobo et al., 2000; Thomas and Wolman, 1972 [1970]).

Various models of municipal political participation of Blacks, and particularly the effects on political relationships of approaching ethnic succession within a majorityWhite municipality, have been particularly well documented. It has been demonstrated, for example, that Blacks fare better politically when majority-White cities elect council members through district elections as opposed to at-large elections (Bridges and Underwood, 2000; Bullock, 1984, 1992; Welch, 1990), but the most powerful offices in city government-mayors and elected city managers - still tend to be elected at-large, meaning that a Black majority is the only guarantor of continued electoral success in such 
positions. White responses to ethnic succession by minority groups at the municipal level have covered a wide range of actions which have included: attempted annexation of White communities into the city to maintain for as long as possible a White majority (Barker et al., 1999; Fleischmann, 1991, 2000); anticipatory changes in the structure of local government from at-large to district elections in order to preserve some White political representation (Barker et al., 1999; Fleischmann, 1991); use of systems of political patronage and "machine" politics to achieve similar ends (Barker et al., 1999; Orr, 1997); transference of some powers of the city government to extra-municipal bodies such as county or state governments (Barker et al., 1999; Fleischmann, 2000; Vogel and Stowers, 1991; Warren, 1997); efforts to bring middle-class members of a generally poor minority group into economic positions which would induce them to be supportive of White business aims (Perry, 1997; Pierannunzi and Stone, 1997); assumption of an active White minority role in city politics (Barker et al., 1999; Whelen and Young, 1991); and wholesale abandonment of the city for suburbs (Rich, 1991). Other sources of municipal research review the various kinds of treatment afforded Blacks when they present a sizable minority of the community, where they may at various times be included or excluded from governing coalitions (Barker et al., 1999; Feagin and Parker, 1991; Glassberg, 1991; Keiser, 1997).

The diluted state of Black political power is exacerbated by disparities in the power of political institutions, including the differences between the House of Representatives and the Senate (Baker, 2001), and the relative power in the Senate accorded to states of varying sizes (Lee and Oppenheimer, 1999). At the presidential level, an examination of the voting patterns of Southern states, which have the highest 
Black proportions in their populations, reveals a similar dilution of the influence of Blacks in electoral politics (Barker et al., 1999; Black and Black, 1992). The relationship between Blacks and political parties is also examined, and researchers generally find party politics to be lacking in utility for Blacks. This, it is popularly claimed, is the result of overwhelming Black loyalty to the Democratic Party, which leads Democratic candidates to feel that they need not actively advocate Black concerns in order to maintain this loyalty, while Republicans feel that they can not win Black support anyway, so they position themselves on the opposite side of the concerns of Black voters in order to maximize White support (Aberbach and Walker, 1972[1970]; Barker et al, 1999; Frymer, 1999; Lusane, 1994; Morris, 1992 [1975]).

Anthropological and historical accounts describe the circumstances of history which initiated the Black African Diaspora, bringing the Black population to America to be held under conditions of subjugation, even after this group was formally freed from the institution of slavery (Edgar, 1998; Meier and Rudwick 1976; Segal, 1995). More focused examinations specifically scrutinize the Black migrations of the Twentieth century, providing anecdotal accounts of the Great Migration from South to North (Adero, 1993) and the ongoing return migration from North to South (Stack, 1996; Cohn, 2001). Another relevant area of examination is that of previous circumstances under which a majority-Black state has existed, both under slavery (Edgar, 1998; Koger, 1995; Wood, 1974), and during Reconstruction (Edgar, 1998; Gillette, 1979; Vincent, 1976). Edgar's (1998) South Carolina: A History discusses these issues within the context of the comprehensive history of that state, while Vincent's (1976) Black Legislators in Louisiana During Reconstruction is specific to the period and locale described in the title. 
Definitions of race are also important in defining the dividing lines between the populations under examination, and the development of these definitions has also been examined in historical context (Davis, 1991; Lavender, 1999b; Wright, 1997 [1994]).

While some mention is made in historical context of various discussions of establishing a Black state (Meier and Rudwick 1976; Segal, 1995), and even of using population patterns and migration to consolidate political power (Barker et al, 1999), no previous sociological examination has been done of the possibility of creating a majorityBlack state, or the political consequences of the existence of such a state, however it may come about. This is the topic which I will address. 


\section{STRUCTURE AND FORM}

This analysis will begin with an historic overview of the circumstances which have brought about the current situation of under-representative Black political power. In the course of this overview, it will discuss the development of the current remedies that are being employed to rectify this situation, and it will then determine why these efforts are insufficient to address the problem. Building on the shortcomings of current remedies, I will propose a new strategy for examination: the possible use of a directed migration from one state or set of states to another state, with the intent of establishing a Black majority in the "target" state, as a method by which this minority group could consolidate political power. I will then discuss how this strategy might best be implemented, and make an effort to determine the likely consequences of implementation, success, and failure.

Before I set about discussing the specific proposal under examination, I must be completely clear as to what is at issue and what is not at issue. This thesis neither advocates nor opposes the primary concept under review, which is the aforementioned strategy of a minority group establishing a majority in a state. I will only examine the feasibility of such a strategy and the likely consequences, using existing statistical data and anecdotal evidence to evaluate several models depicting potential ways in which such strategy might be approached.

The strategy being examined in this thesis does not suggest the creation of a state or states where only one ethnic group is represented; rather it discusses the possible establishment of a simple ethnic majority (essentially fifty percent plus one) of the 
eligible voters within a given state or set of states. Such a strategy would not necessitate any kind of segregation, either legal or social, within any state; indeed, while it is reasonable to anticipate that groups within such a state might tend to self-segregate, the most optimistic outcome in a state so evenly divided between ethnic groups is that it could prospectively serve as a model of integration and cooperation between these groups. The strategy being examined does not suggest that the entire population of a minority group should move to a single area, but merely examines the possibility of a migration being undertaken by a sufficient number of persons from that minority group (which may be a surprisingly small proportion even of the entire population of that group) to establish a majority within a given state.

The strategy being examined does not suggest the creation of a separate nation or 'nation-state' or 'republic' within the boundaries of the United States, nor does it consider any alteration in the existing powers of state governments. The concept, rather, is predicated entirely on the ability of a minority group to use the existing elements common to the political structures of individual states to advance their particular concerns in the same way that the White majority is already able to do in every state in the country. This strategy does not require or even suggest that any existing boundaries be redrawn, or that existing state or federal laws be changed; indeed, it requires the stability of existing boundaries and many existing laws.

On a more individual level, the strategy being examined does not suggest that any individual property be redistributed, or that land be 'set aside' for members of a particular ethnic group, or that market forces and individual determination be overruled by intervention from any element of government or any other organization. Instead, it 
essentially examines the possibility of focusing migration which is already occurring, through the same mechanisms that already determine where people will move and how they will establish themselves in their destinations. Most importantly, this strategy does not suggest that persons be coerced to move against their will or persuaded to migrate under false pretenses; it only examines what the possible outcomes might be of people choosing to act towards a specific collective political goal.

Because this paper deals with questions of ethnicity and refers to the relations between specific ethnic communities, I feel that this is an opportune place to present a few notes on the writing style. Much debate has centered on what terminology ought to be used to refer to ethnic communities or to members of various ethnic groups, particularly those of Black African descent. Once-popular terms such as "Negro" and "Colored" have fallen out of favor, and are even taken with offense by some, while "African-American" and "Black" remain popular. In addition, some "Black" communities of West Indian descent maintain a cultural heritage and identity distinct from Blacks with long-standing American roots. "Black" and "White" are obvious misnomers in describing the individuals to which these labels are ascribed, but they are also succinct and universally understood. Throughout this paper, persons of African descent will generally be referred to as Black, or occasionally as African American, while persons of European descent will be referred to as White. I choose to follow the example of Clarence Lusane and capitalize these terms, because of the formality with which they designate the groups under examination. In quoting the text of other authors, however, I will, of course, preserve their style and terminology. 


\section{CHAPTER I.}

\section{The Development of the Modern Dilemma}

In order to understand why any strategy is necessary to advance the political power of a particular minority group, it is necessary to first understand the circumstances that have held back, and continue to hold back, the natural progress of this group in relation to other minority groups and to the majority group. While the history of Black oppression in the United States is a fairly familiar subject, some elements of this history have a particular bearing on the modern-day questions of the distribution of political power. The fact that Blacks require a unique solution to their disenfranchisement derives from the unique circumstance of their oppression, beginning with the development of economic slavery justified by the assertion of moral, cultural, and racial superiority on the part of the oppressor.

Since the time of slavery, Blacks and Whites have struggled with the legacy of White domination and Black oppression, as different factions within each group have attempted to find solutions that accommodated their perceived interests. In many cases, these solutions have involved the exploitation of the majoritarian control which is the foundation of the democratic process. Both geographic mobilization and the manipulation of political boundaries have been used quite frequently as a means to influence the existence of voting majorities for this purpose, most often to the benefit of those in the White majority. 


\section{Colonization and Slavery}

The practice of slavery - persons being held as property by others - was common throughout the world long before the voyages of Columbus spurred a European race to colonize the newly 'discovered' lands of the Americas. However, the nature of slavery as it was practiced in Europe and Africa was substantively different than that which was to develop in these colonies. Segal (1995) notes that as early as the year $1300 \mathrm{AD}$, European records began to distinguish Black slaves from White slaves, but it was not until the colonization of the Americas began in the 1500s that this distinction would begin to carry legal significance. In the fifteenth and sixteenth centuries, the concept of slavery shifted away from the ethnically neutral social status held by sentenced criminals, children sold by their peasant families, and conquered subjects of enemy nations, becoming instead an economic status determined by ethnicity.

Because of clear physical and cultural differences, Black Africans were already widely thought of by White Europeans as 'inferior' and 'barbaric' people, not worthy of the rights accorded to 'civilized' people. As Segal (1995) explains, "white societies that had prided themselves on their moral as well as their material progress excused the exploitation of blacks, first by maintaining that blacks were naturally inferior to whites and then, as this doctrine became increasingly unsustainable, by asserting the cultural backwardness of Africa" (p. 5). This classification was the basis for the development of the modern concept of slavery. Slaves in previous eras could bear free children, for example, and could expect the opportunity to earn money and buy their freedom, or be freed upon their master's death; but slaves who were accorded that status because they 
were thought to be inferior could rarely aspire to freedom by any means other than escape and evasion, and their children were automatically accorded slave status, even if one parent was free. Slaves in earlier systems could be educated, and some even served as teachers, but slaves deemed inferior were generally discouraged from and often prohibited access to education. Slaves under earlier systems were more likely to be household servants, living under the same roof as their master. Under the regime of intense agricultural production in the colonies, the slaves were often geographically separate from their 'owners,' and for this work, they 'needed to be regarded not as people at all but as pieces of machinery in a productive process, with their value based on the money to be made out of them, minus the capital expended on their purchase and the share of revenue devoted to their operational costs" (Segal, 1995, p. 17).

This same assertion was used by colonizing powers as a basis for early attempts to enslave the native population of the Americas, who "proved to be increasingly unhelpful," because they were prone to European diseases, were unable to withstand the grueling routine of slave labor, and could easily escape to some safe haven because they were frequently familiar with the area (Segal, 1995, p. 15). Throughout the colonization period, White traders captured or (more frequently) purchased from various African kingdoms millions of Blacks as slaves, most of whom were the prisoners of wars between these kingdoms. These slaves were transported across the Atlantic ocean, under brutal and harrowing circumstances, chained closely together in tightly packed ships, to European colonies in the Western hemisphere. Because the colonies throughout the Americas were developed in tune with the slave trade, slavery became an integral part of their economies. As Meier and Rudwick (1976) note, of all Black Africans brought to 
the New World, "less than 5 percent were imported into British North America" (p. 39), the first twenty having been brought to Virginia as indentured servants in 1619 (Bennett, Jr., 2000; Meier and Rudwick, 1976; Segal, 1995). By the middle of the 1600s, it had become legally established that Whites in the British colonies could not be enslaved, but that Blacks brought into these colonies could and would be slaves for life. Meier and Rudwick (1976) note that "Negroes entering the colony thereafter lacked indentures, and slavery would be limited to people of African ancestry" (p. 42).

Most Black slaves taken from Africa, however, ended up in Brazil, Cuba, and Hispaniola, where they were more than likely to be literally worked to death. Meier and Rudwick (1976) point out that in Brazilian and Caribbean colonies, "the death rate of slaves was so high that during most of their history the slave populations did not reproduce themselves and were sustained only by large imports from Africa" (p. 73). From the beginning of the trade in African slaves, reports of this brutal treatment inspired strong abolitionist sentiments among humanitarians in Europe. Such sentiments were later embraced by some American colonial leaders on the same moral grounds that caused them to oppose the tyranny of the monarchical governments that had established slavery in the first place, and were among the driving forces behind anti-totalitarian revolutions throughout the colonies, including the American Revolution. The treatment of slaves in the British colonies, however, was less hostile to the point that it was possible for a large and regenerative population of native-born Black slaves to develop. Meier and Rudwick (1976) state that conditions were different in the United States, where "after about $1720 \ldots$ natural increase rather than importations was the chief factor accounting for the striking increase in the slave population" (p. 73). Indeed, because of the economic 
value of slaves and the high costs associated with their importation, reproduction was encouraged, occasionally even leading to planned 'breeding.'

By the time of the American Revolution in 1776, slavery in what would soon become the United States had become divided along geographic lines, as the South was more environmentally suitable for the kinds of plantation crops for which slave labor was most useful. Increasing Southern support and Northern opposition to this practice developed, highlighted by the fact that "beginning... in 1776, six of them banned the importation of Africans" (Segal, 1995, p. 53), and most of the Northern states had ended slavery in their territories by 1808 . Segal (1995) states that "in 1808 , the federal government banned new imports from the [slave] trade, while leaving the institution of slavery itself to survive in such states as maintained it and to spread as it might only south of the Ohio River" (p. 53).

The slave population had by this time grown large enough to be completely selfsupporting, and a new set of social circumstances arose to accommodate political reality. Southern Whites were keenly aware that Northern opposition to slavery was continuing to grow, and they feared that the more powerful North might eventually take steps to end altogether this institution which Southerners had come to feel was the backbone of their economy and, as a tradition, vital to their way of life. Occasional slave revolts had also led White Southerners to become ever more fearful of their slaves, and of the possibility of slave rebellions on a massive scale, resulting in strict controls over the activities of their slaves, and of free Blacks in the South. Systematic idiosyncrasies, such as the fulfillment of indentured servitude from Blacks brought to America prior to the period of slavery and the manumission of some slaves by their owners, had led to the development 
of a small but consistent population of free Blacks, but they were legally and socially treated as inferiors and were generally denied any role in political processes throughout the nation. Barker, Jones and Tate (1999) describe how "initially given the right to vote in most states, free blacks were almost completely disenfranchised by the 1840 s" (p. 14) In some instances, the tension developing in the decades before the Civil War led to attempts to re-enslave Blacks who had been free for decades. Koger (1995) describes, for example, how free Blacks in South Carolina who could not prove their non-slave status were aggressively sought and enslaved as the war drew near (p. 78).

The fact that Blacks were disenfranchised in the North, and were even barred from holding offices in some abolitionist organizations, is indicative of the universality of their lower social standing. Meier and Rudwick (1976) note that even staunch abolitionists such as Thomas Jefferson and Abraham Lincoln did not believe that Blacks were truly the equals of Whites, and "thought it unlikely that Negroes and whites could live peacefully with equal rights in the same country" (p. 159). Long before the actual event of Emancipation, both friends and foes of the abolition movement pondered the question of what should be done with masses of freed slaves, should anti-slavery efforts succeed. Even the most ardent supporters of ending slavery were not necessarily prepared to accept these multitudes as equal participants in American society. The two ideas that were most popularly discussed as means to deal with a newly freed Black population were the repatriation of former slaves to Africa, and the colonization of new lands, on this continent or abroad.

Barker, Jones and Tate (1999) state that the strategy of dealing with the Black political presence though population transfer "received support from diverse quarters, 
including prominent whites such as Thomas Jefferson and President James Monroe. These forces, led by the American Colonization Society, advocated emigration of blacks to Africa" (p. 16). Appleby (2000) describes how "Benjamin Lundy, the most ardent Quaker foe of slavery, traveled widely in the west to find a location for a free black colony, agitating for colonization in his Genius of Universal Emancipation” (p. 228), while Meier and Rudwick (1976) say that Thomas Jefferson "proposed that freed Negroes be settled in their own society in the interior of the continent, far removed from the whites" (p. 51), and that Abraham Lincoln "cherished the notion of settlement in Colombia's Chiriquí Province (now in Panama)” (p. 159).

Free Blacks in the North, disillusioned with their own poor treatment and political disenfranchisement, were not opposed to the idea of colonization as Meier and Rudwick (1976) point out:

In 1854,1856 , and 1858 , black colonizationists held their own national conventions. They differed among themselves as to what would be the best site. Some opted for the Caribbean area, especially for Haiti, whose ruler encouraged their aspirations. Several preferred Lower California and the Far West of the United States. But the most popular place was Africa. (p. 151).

Although there were some small settlements of American Blacks in Africa during the first half of the 1800 s, the vast majority of Blacks in the United States remained enslaved in the South. As long as slavery remained the backbone of the Southern economy, the resettlement schemes envisioned by Jefferson, Lincoln, and other colonizationists would exist only in the minds of those who advocated for emancipation. 


\section{Emancipation, Reconstruction and Retreat}

In the 1860 s, Southern states reacted to the election of abolitionist Abraham Lincoln and the implied threat of slave emancipation by declaring secession from the United States. The North responded with military force, and ultimately fulfilled the fears of the South, ending the regime of slavery during the Civil War. The Emancipation Proclamation declared in 1863 that slaves held in the territories that had rebelled were now free, and two years later the Thirteenth Amendment to the Constitution determined that the rest of those enslaved would be free as well. Lincoln's ambition to colonize the freed slaves in other parts of the hemisphere died with his assassination, and the Radical Republicans who dominated the Congress thereafter were determined to keep the newly freed slaves in the South, for several reasons. Chiefly they sought to balance the political power of Southern Whites by establishing among former slaves the right to vote. Some were also intent on punishing the South for the rebellion by forcing them to live among their former slaves, while others preferred to encourage Blacks to stay in the South in fear that they might choose to move to the North. Ex-slaves also came to prefer the idea of remaining in the United States because the very act of their emancipation was sufficient "to renew the Negroes' faith in the vision of a racially egalitarian and integrated American society" (Meier and Rudwick, 1976, p. 152).

Some colonization efforts did continue after the war, but Gillette (1979) notes that "mass deportation of blacks to Latin America or Africa was more extensively debated than actually undertaken" because "emigration on so large a scale was too difficult and too expensive" (p. 191-2). He states that some leaders, both Black and White, had 
suggested the designation of "a new federal territory or state reserved as a black enclave" but that ultimately, "most Negroes remained where they had always lived, and most northerners were thankful that it was generally not in the North" (p. 192). Furthermore, the aims of the Northern White Republicans in control of the federal government during this period were best served not by colonization or relocation, but by empowering the Southern Black population politically. As Gillette (1979) explains, "the Republican party recognized Southern black suffrage as the only counterpoise to Democratic resurgence in the South" (p. 7). Meier and Rudwick (1976) also note that a simple lack of foresight by the politicians of the North was another important factor in the treatment of freed slaves. Many had not anticipated that emancipation would actually occur, and therefore the freedom of the enslaved led to much indecision as various ideas were cast about with little firm resolution about how to provide for the former slaves and insure their rights.

Blacks throughout the South embraced the opportunity to participate in the electoral process both as voters and by serving in various offices. As W.E.B. Du Bois (1989 [1903]) noted, "the ballot, which before he [the Black American] had looked upon as a visible sign of freedom, he now regarded as the chief means of gaining and perfecting the liberty with which war had partially endowed him" (p. 5). However, Black political power still existed at the pleasure of Whites who guarded their role in the process, and the exercise of this power was thus under the control of their White Republican allies. This was the case even in Louisiana, Mississippi, and South Carolina, where Blacks actually outnumbered Whites during the period of Reconstruction. In Louisiana, Blacks had only a slight majority, but Blacks outnumbered Whites by over $36 \%$ in Mississippi and by nearly $50 \%$ in South Carolina (Smallwood, 1998). Meier and 
Rudwick (1976) point out that despite Black majorities in the general populations and the accusations of Black political domination made by Southern Whites, the highest positions of power remained inaccessible to Blacks:

Actually, at no time can blacks be said to have been in control of any Southern state. None was ever elected or nominated for governor. Only in the lower house of the South Carolina legislature were black men ever in the majority. South Carolina was the only state with a black serving as a supreme-court justice, Mississippi the only one that sent Negroes to the United States Senate. Obviously, even in these two states, where Negroes were over half the population, they never really controlled the governments since the highest state office eluded them and the majority of important offices were always in white hands. (p. 187).

Despite the lack of true control in the hands of Black politicians, former slaveowners feared the possibility of Blacks using this power to exact revenge for their treatment as slaves, and to force their acceptance into all areas of society. Southern Whites in general resented the presence of Blacks, whom they generally considered to be inferior and incapable of exercising good judgment, holding positions of authority in their governing institutions. These Southern Whites therefore generated a mythology about the corrupt nature of a government with Black participants. Vincent (1976) states that the "classic picture of the Louisiana legislature, and other Reconstruction legislatures, depicts a body controlled by evil whites and ignorant Negroes who combined to steal the state blind" (p. 78) and that "a popular view of black legislators [during Reconstruction] is that they held hostile feelings towards whites and wanted to punish them" (p. 222). White South Carolinians, Edgar (1998) reports, were prone to "Denigrating and dismissing black officeholders as illiterate, venal, propertyless rogues" (p. 388). 
Debunking the myth of vengeful Black officeholders, Vincent (1976) concludes that "the contrary is closer to the truth. Blacks did not enact vindictive laws designed to deny whites certain privileges" but in fact, Blacks "worked constantly to secure universal education and improved educational facilities, including those for whites" (p. 222). Vincent further highlights the fact that Blacks in general were more interested in equal treatment than in actual social integration with Whites, claiming that the majority of Blacks "were willing to forego enforcement of the integration clause in the [Louisiana] constitution if schools were established in black communities" (p. 222). Edgar (1998) states that when Blacks were "offered the rare opportunity to send their children to integrated schools, most opted instead for all black ones" (p. 381). In South Carolina, Edgar (1998) notes, emancipated Blacks quickly established all-Black townships "to remove themselves and their families from any reminders of slavery" and as "a matter of self-protection and a way to avoid violence" (p. 382). This strategy had some negative repercussions, as the "withdrawal of blacks into their own communities, while giving them freedom from white supervision, tended to increase white anxiety" (p. 382).

Emancipation and enfranchisement had proven to be a double-edged sword for newly freed and politically enabled Blacks, for Southern Whites now saw their presence as a political threat to be fought through a campaign of terror and fraud. Gillette (1979) provides a counterpoint to the hopes expressed by DuBois, noting that "armed with the ballot to make them more secure in their freedom, many blacks found that the privilege in fact jeopardized their lives or their livelihood" (p. 37). The North lacked the will to enforce Negro suffrage, and as a consequence Gillette (1979) asserts, "political violence flourished unabated, and electoral fraud was commonplace, sophisticated, and highly 
successful" (p. 43). In fact, despite Northern opposition to slavery, many Northern Whites disliked Negro enfranchisement as much as their Southern counterparts. Gillette (1979) points out that "slavery was sectional, but racism was national" and that Negro suffrage "was almost always opposed in northern state referendums and generally evaded by northern Republicans" (p. 7).

While the Civil War had resulted in emancipation of enslaved Blacks, Southern Whites had agitated for Northern withdrawal and against Black participation in the governance of their states since the war had ended, and Meier and Rudwick (1976) suggest that by the latter half of the 1870s, "the North had changed its mind" (p. 192) about political empowerment to Blacks. They state that even those "who had been most sincerely interested in the Negro became tired, disillusioned with the freedmen, and enamored of the idea of sectional reconciliation" (p. 192). Vincent (1976) adds to this analysis his contention that by 1877 , "the national Republican party had abandoned southern blacks" because Republicans "no longer needed their votes to sustain [their] power" (p. 217). Thus the North ended its occupation of the defeated South after about a decade and a half.

Once Blacks had lost the protection of Northern agents, their situation quickly regressed into another cycle of repression almost as bad as slavery. Whites strove to return Blacks to as close a condition to slavery as possible, which was accomplished through political means, economic subordination, and violence. Political avenues to oppression included the establishment of 'Black Codes' and other 'Jim Crow' laws which had been prohibited during the period of Reconstruction, which set limitations on the legal rights of Blacks and relegated them to segregated facilities. As Grofman et al 
(1992) note, without Northern interference, "the South showed no inclination to protect the right of blacks to vote, and, in fact, began to institute a series of measures designed to prevent blacks from casting ballots" (p. 6). These included laws that required individuals to demonstrate literacy or property ownership, or pay fees beyond the means of Black families in order to claim the right to vote, as well as devices such as "long residency requirements and very short registration periods" (p. 7). Other techniques were used to dilute the strength of the Black vote, including "racial gerrymandering, at-large election systems, annexations or deannexations, or abolishing local elections for certain offices altogether and making such positions appointive" (p. 8).

The economic element of this repression was embodied in the practice of sharecropping, a system in which Blacks were allowed to farm a piece of land owned by a White landlord in exchange for a certain amount of their production. However, the system was set up to work heavily in favor of the owner, who would manipulate his tenants into debt, forcing them to continue working long after the value of their work exceeded the costs to the landowner of subletting his property. This system was less obvious than slavery, and easier to legitimate, as it could equally be applied to keep poor whites in a similar state of perpetual debt. Blacks so encumbered essentially became legally bound to the land, required to work for the landowner until the debt was repaid.

In addition to these nonviolent tactics, brutal violence was perpetrated by 'White riders' in organized groups such as the Ku Klux Klan and similar bands, who terrorized Blacks in order to keep them in line. These groups had come into existence shortly after the end of the Civil War, and had been suppressed with limited success during Reconstruction. The withdrawal of the North allowed these groups to carry out their 
activities unhindered, which included the frequent lynching of Blacks who attempted to assert their rights.

Many Blacks were willing to migrate towards better circumstances. Smallwood (1998) reports that in the late 1870s, "Pap Singleton, a minister, sent out a call for all blacks to go west to make a new start away from the racial persecution in the South" and eventually lead over 60,000 Southern Blacks in "a massive exodus to Kansas" (p. 99). Wilson and Ferris (1989) describe one of the first actual attempts by Blacks to use migration to shed the burden of White domination and at the same time gain the benefits of statehood, telling the story of how "Edward P. McCabe, who enjoyed a successful career as a Kansas state politician, quit the town when the unassigned lands of Oklahoma were opened for settlement in 1889." The authors explain that "McCabe envisioned the creation of an all-black state when he established Langston, Okla., in 1890" (p. 198, emphasis added). Meier and Rudwick (1976) also describe "the attempt to erect an allblack state in Oklahoma... initiated by E. P. McCabe, formerly state auditor of Kansas" (p.248). They describe the scenario where, "disillusioned when the Republicans failed to renominate him, McCabe urged blacks to migrate to the Oklahoma Territory when it was opened for settlement. He painted a vision of a black-governed commonwealth, sending representatives and senators to the United States Congress" (p. 248, emphasis added). The relative success of the attempt was hindered by the conditions of the time, which allowed Whites to prevent the culmination of McCabe's idea. As Meier and Rudwick (1976) describe, from 1891 to 1910 "about twenty-five towns were established. The migration aroused fears in the whites and eventuated not in political power but in disenfranchisement" (p. 248). 
McCabe's effort, although noteworthy, was unusual in its straightforward intention of establishing Black political power through a mass migration. His effort failed because of the willingness of Whites of that era to use both violence and political maneuvers designed to disenfranchise Blacks, who lacked the resources and the allies necessary to overcome such barriers. There were in fact, three more popular approaches to the situation of Black disenfranchisement posited by Black leaders of the postReconstruction period. Booker $\mathrm{T}$. Washington advocated acquiescence to social subordination and development of economic self-reliance, admonishing Blacks against migration because he simply did not feel that they could ever truly escape White racism in that way. W.E.B. DuBois championed a more confrontational approach which emphasized education and political initiative. Marcus Garvey, who came to prominence in the 1920s, endorsed Black nationalism and relocation, suggesting Blacks should abandon the United States altogether and settle in a different part of the world.

While large numbers of Blacks did choose relocation to escape repression, they were not seeking to escape the United States. Instead, Southern Blacks moved to the North in several large waves between 1910 and 1950 and Barker et al. (1999) state that in Northern cities, "the migration of blacks from the South increased the black population such that it became an important political force" (p. 18). It is important to note once again that there was no lack of racism in the North, and that much research has suggested that ethnocentrism is often exacerbated by the presence of a large number of members of a minority group (Taylor, 1998). However, states in the North had given up slavery long before those in the South, and Northerners continued to be more liberal in their views 
regarding relations between races, despite friction between urban Whites and immigrating Blacks.

The choice of internal migration also highlights the American identity of the Black population. Appleby (2000) states that the decade of the 1920s "were a watershed for free blacks who consciously moved away from an identity with Africa in order to establish their claims to full citizenship in the United States" (pp. 228-9). This resurgent sense of national identity prevented the Communist Party of the United States from making significant inroads into the African American community, despite efforts in that direction in the 1930s. These efforts included an addition to the party platform calling for the establishment of an autonomous Black 'Republic' in the U.S. South, in the style of the Republics of the Soviet Union (Meier and Rudwick, 1976). This enticement failed precisely because Blacks saw themselves as Americans, entitled to their opportunity to pursue the American dream despite the involuntary immigration of their ancestors. The Black community which the Communists pursued "had no more desire to settle in a separate nation than to go back to Africa" (Abraham, 1991, p. 205).

As Swain (1995) points out, Black political activity was profoundly transformed by "urban migration, which made possible the concentration of large numbers of blacks in congressional districts in cities such as Chicago, Philadelphia, Detroit, and New York" (p. 36). There, large Black populations became sufficiently large and concentrated to significantly influence congressional elections in their districts. All previous Black congressmen had come from the South where their election was enabled by Reconstruction policies. The last of the post-Reconstruction Black congressmen, George White of North Carolina, was able to remain in office until 1901. But it was from one of 
the great Northern cities-Chicago-that the Black presence in Congress was restored after a twenty-eight year hiatus, with the 1929 election of another Black Republican, Oscar DePriest. Once the Black migration had enabled Blacks to return to the Congress representing districts in the North, Blacks would maintain that presence continuously and use it to advocate their concerns at the federal level. Swain describes several significant differences between Reconstruction-era Black members of Congress, and those elected after 1928:

In the nineteenth century, blacks served short terms; in the twentieth century, they have had continuous service and have risen in seniority. In the nineteenth century, all black representatives were Republican; in the twentieth century, almost all have been Democrats; In the Reconstruction era, 92 percent of the blacks came from congressional districts with black majorities; in the twentieth century, black candidates have no longer been dependent on black majorities as their only means to reach Congress. (pp. 33-4)

The return of Blacks to the United States Congress was a factor in the resurgence of Black efforts to obtain equal rights, as was the experience of Black soldiers returning from the socially liberating atmosphere of military service in the Second World War. Some moderate Southern White politicians of this era, particularly those in urban settings, also saw the value of recruiting Black voters. Fleischmann (1991) describes how, in the 1940's, Atlanta mayoral candidate William B. Hartsfield "cemented a coalition between blacks and middle-class whites that excluded poor whites, the staunchest supporters of segregation. This was in marked contrast to other large cities in the South, where white politicians seeking municipal offices tended either to unite white voters in opposition to black-supported candidates or to build coalitions along class lines rather than racial lines." (p. 101) 
Of equal significance was the change in the nature of the Supreme Court, which had heretofore been complicit in upholding many of the Southern disenfranchisement techniques. In the decades after the retreat from reconstruction, the Court had upheld segregation, literacy tests, poll taxes, and similar measures. Grofman et al (1992) describe a gradual change in the Court's attitude beginning in 1915, when "in Guinn v. United States, the Supreme Court declared Oklahoma's 'grandfather clause' was unconstitutional" (pp. 10-11). In 1939, the Court ruled against an excessively brief registration period in Lane v. Wilson (1939), and Barker et al (1999) trace the beginning of the Civil Rights movement to the Supreme Court decision in Smith vs. Allwright (1944), which eliminated the 'White primary' and thus opened the door for Blacks to participate politically in the South. "Following the death of the white primary in 1944," they write, "black political activity increased significantly. Assimilation/integration became the dominant policy orientation among both black and white factions" (p. 19).

The White primary had removed Blacks from the process of nominating candidates for office, and its defeat before the Supreme Court signaled that the Court would be willing to intervene to dismantle the apparatus of disenfranchisement. It is important to note that the re-entry of Blacks into the political process in the South was hardly guaranteed by these measures. However, efforts towards that end were certainly re-invigorated. 


\section{The Political Re-Awakening of African Americans}

Before the next major upheaval in the segregated society of the deep South, the conditions of segregation and disenfranchisement were so deeply imbedded that Lewis Coser (1956) wrote that the "lack of conflict between Negroes and Whites in the South, in contrast to frequent conflicts in race relations in many a Northern city has often been taken to indicate that Negro-White relations are more stable in the South. Such a conclusion appears to be unjustified. The absence of conflict itself does not indicate the absence of feelings of hostility and antagonism and hence absence of elements of strain and malintegration" (p. 82). Only a year after Coser wrote those words, violent conflict would arise again, and federal troops would be marching in the streets of Little Rock, Arkansas, enforcing the first court order to integrate a public school (Bennett, Jr., 1992).

In the 1950s, Blacks began feeling empowered in sufficient numbers to conduct protests, marches, and acts of civil disobedience on a large enough scale to disrupt the social regimen of the South and attract national and even international attention. Buoyed by legal victories, such as the Supreme Court's decision in Brown v. The Board of Education (1954) that segregated facilities were inherently unequal, and aided by particularly sympathetic allies in the Kennedy and Johnson administrations, Martin Luther King and other civil rights leaders encouraged White Northern opposition to segregation laws. The Civil Rights movement of the 1960's, backed by the intervention

of the federal government, ended the repression embodied in Jim Crow laws, White riders, and sharecropping. 
Ultimately, these efforts led to the passage, and more critically to the enforcement, of Federal statutes insuring the right to vote and equal access to economic institutions and social institutions such as schools. This enforcement was often necessarily facilitated through the use of armed National Guard troops, and led to such dramatic sights as Governor George Wallace of Alabama bodily blocking the doors to a schoolhouse and declaring "segregation now, segregation forever!" At the end of the day, Governor Wallace did move-not only in allowing the schools to become integrated, but eventually abandoning segregation as a political position in his (successful) future campaigns. The period was so dramatic in altering the status of Blacks and the relationship between the races in the South that Blacks often refer to it as the 'Second Reconstruction' (Robinson, 1998).

Three policies were established by Congress, endorsed by the courts, and enforced with the full capability of the Federal government during this period as the primary tools in this fight for equality. The first was institutional integration (or 'desegregation'), which was imposed with the goal of breaking down the social barriers which had long upheld the superior status of Whites and relegated Blacks to inferior schools and poor locations on trains and buses. The second tool, affirmative action, was developed to level the economic and educational playing fields, giving Blacks at least some opportunity to make the gains needed to offset the denial of such opportunities in past generations. Finally, unwavering support for the principle of enfranchisement insured that voting rights were carefully observed in order to bring about Black political viability. This effort was later fortified with legislation which prevented state governments from using election systems or fashioning electoral districts designed to 
deny Blacks effective representation, requiring instead that majority Black districts be designed in some cases to insure the possibility of Black representation for Black voters.

Black political enfranchisement was embodied in the Voting Rights Act of 1965 (VRA), a piece of legislation which finally and decisively affirmed the right of Blacks to vote unhindered. The act banned a variety of stumbling blocks to potential voters, such as literacy tests and poll taxes, and gave the federal government broad power to insure that eligible voters were able to register and cast their ballots unfettered by state action. Grofman et al. (1992) note, however, that "even before the Voting Rights Act was passed, it was apparent that voting was only the first hurdle to effective participation. The resurgence of black electoral participation brought to light a second-order obstacle that had remained obscure as long as blacks were completely excluded from the political process. Jurisdictions that wished to continue to discriminate against blacks simply moved from denying them access to the ballot to more sophisticated schemes developed to dilute the impact of their new voting strength" (pp. 23-24).

The 1960s also saw the resurgence of Black nationalist movements. Meier and Rudwick (1976) describe the development of "such Marxist-oriented revolutionary movements as the Black Panthers, founded in Oakland California, in 1966, and the Republic of New Africa, founded in Detroit the following year. Both advocated forms of territorial separatism. The Black Panthers... espoused black control of the central cities" (p. 311), while Barker et al (1999) state that the "Republic of New Africa... vowed to establish an independent black nation in the Southern Black Belt" (p. 19). These groups, however, represented the extreme position of the civil rights movement. 
Mainstream participants in the civil rights movement were more generally concerned with obtaining equal rights for Black Americans, and for gaining recognition of their standing as contributors to the nation as a whole. They were generally not, however, engaged in a wholesale assimilationist effort, which would occupy the opposite extreme of the spectrum of responses to discrimination from that of the Black nationalist organizations. While Blacks had long since determined that their national identification would be with the United States, Davis (1991) notes that during the 1950s and the 1960s, "black leaders concluded that complete assimilation of blacks as a people into white community life is neither possible nor desirable. The general black rejections of total separatism in favor of the strategy of integration into the dominant educational, economic, and political institutions has been designed to obtain greater equality of opportunity, not total assimilation" (pp. 167-8).

Black urban politics in the South developed as it had in the North with the growing concentration of Blacks in large Southern cities such as Atlanta, New Orleans, and Birmingham. William Hartsfield's Atlanta coalition between Blacks and moderate Whites, for example, succeeded once again in 1961, when Hartsfield's successor, Ivan Allen, Jr., used it to defeat segregationist mayoral candidate Lester Maddox. It was becoming clear by this time that Blacks would soon comprise a majority of Atlanta residents, and within a few years Whites began taking steps to insure that the methods previously used to bar Black political participation could not or would not be used against a White minority. Fleischmann (1991) reports that the "most apparent changes in Atlanta's governmental structure occurred with the 1973 charter, which manifests the recognition by Atlanta's leaders that the city would have a permanent black majority. A 
Charter Commission appointed by the Georgia General Assembly drafted a document replacing the at-large Board of Aldermen with a mixed system of 12 district and 6 atlarge members... district seats guaranteed Whites more representation than they would have secured under an at-large system" (p. 100).

Around the same time, Fleischmann (1991) reports that "Atlanta's last white mayor, Sam Massell, included in his 1973 reelection platform a call for annexation of a North Side area that would have added 50,000 whites to the city" which was a tactic that "Black leaders saw... as a way to maintain a white majority in the city" (p. 110). Stone and Pierannunzi (1997) report another, more conciliatory approach taken by Atlanta's White business leaders, who had their own economic interests to protect. "As it became clear that the city would have a black electoral majority," they explain, "an effort was made to bring the black middle class into the mainstream of the civic life of the Atlanta business community" (p. 169).

Barker et al. (1995) describe similar efforts to first dilute and then co-opt Black political power in Alabama beginning in the 1960s. Black efforts to consolidate their political power in majority-Black cities and counties were obstructed by White political machinations. In the city of Selma during the 1960s, for example, "when black voter registration became sufficient to challenge white dominance, elections were structured in ways that prevented black voters from electing candidates of their choice" through the creation of at-large election systems, gerrymandered districts, and excessively stringent requirements applied against both Black voters and Black candidates (Barker et al., 1995, p. 78). The authors describe how Whites "used racially biased annexation and incorporation schemes to prevent black empowerment. In some counties, heretofore 
unincorporated areas were incorporated within racially gerrymandered boundaries to ensure white majorities" (Barker et al., 1995, p. 79).

When it became inevitable that Black majorities would have the power to elect Black officials in certain Alabama counties "whites adopted a new strategy. Rather than nominate whites who were destined to lose, they decided to develop alliances with certain blacks in order to try to defeat those black incumbents who had led the movement for empowerment and whom whites thought were too radical" (Barker et al., 1995, p. 82). While this may seem to be a negative development in terms of Blacks being able to achieve substantive representation, it is important to note that the enactment of this strategy by Whites does have two distinct benefits for the Black community. The first is that it preserves Black symbolic representation, and essentially signifies the end of White efforts to end such symbolic representation. This second is that it requires Whites to admit that Black office-holders are not inherently harmful to White power, allowing them to focus on the question of which Black office-holder they would prefer. The harm to Blacks seeking representation that is substantive as well as symbolic still exists, and in fact can be seen more palpably in some instances where symbolic representation was never denied.

In Chicago and Baltimore the rise of an independent and substantively effective Black leadership was hampered by the existing machine politics, with which some Blacks chose to associate. Orr (1997) examines Baltimore, another city that developed a Black majority, and states that "the experience of blacks and machine politics in Baltimore confirms earlier research showing that the tradition of patronage and machines can delay black political empowerment. The Baltimore case shows that machines can hamper the 
development of strong, independent black political leadership and foster internal divisions within the African-American community" (p. 213). Barker et al. (1995) reach a similar conclusion about Chicago, a city where Blacks have long been a sizable minority, noting that machine politics and the organizations that supported them "provided blacks with decades of representation, but that representation was 'merely symbolic.' Black political power in Chicago was illusory" (p. 88). Substantive representation, therefore, can be withheld from Blacks either through the denial of any representation, or through the provision of representation that is only symbolic. 


\section{CHAPTER II.}

\section{Success and Failure in the Continuing Struggle}

The passage of the Voting Rights Act of 1965 (VRA) was a major victory in Black efforts to obtain the political representation that many in the Black community feel is necessary to improve the social and economic standing of Blacks in America. The end of voter disenfranchisement by itself has hardly yielded political equality to Blacks, nor has it brought these efforts to an end. Legislation can not by itself change the ethnocentric tendencies of voters, which can be devastating to the opportunities for representation of a group that is consistently in the minority.

The recent focus of members of minority groups, including Blacks, seeking representation has been on redistricting plans designed to secure minority representation where this is possible. Mandated under the VRA and subsequent legislation, such plans have succeeded in promoting the election of minority candidates through the creation of majority-minority electoral districts. However, some researchers suggests that this strategy may have passed the point of diminishing returns, while others go so far as to assert for various reasons that this strategy has actually done more harm than good. Those who assert the harm of this strategy cite in particular the manipulation of these districts by those opposed to effective substantive representation for Blacks, and the isolation of Blacks elected from such districts from the White populations that would be necessary to secure support for a Black candidate for a statewide office. 


\section{Persistent Ethnocentrism in Election Behavior}

A large body of research shows that Blacks seeking statewide office are generally held back by the unwillingness of Whites to vote for Black candidates. Reeves (1997) evaluates the effects of ethnocentrism at the ballot box throughout the nation, contending that "black office-seekers who compete in majority-white settings in the main are unable to attract consistent widespread support because race perniciously influences both the tenor of their electoral campaigns and their outcomes. Nearly a generation after passage of the most stringent federal voting rights legislation ever, we have yet to adequately and fully address the question of ensuring equal political opportunity for black political aspirants who compete in majority-white electoral settings" (p. 9; emphasis is author's own). A number of different theories have been put forth to explain this phenomena, attributing White ethnocentrism to various factors.

For example, Bullock (1984) suggests that ethnocentrism is simply a matter of identification of a commonality, and is partly the result of campaigns which tend to leave the voters ill-informed about the candidates from whom they must choose. He examines the relative success of minority candidates against those in the majority, and concludes that, "some voters turn to race as a cue if they find the competitors' policy stands equally attractive. Inability to distinguish the candidates' policy positions may result from inattention by the voter, lack of specificity by the candidates, or a genuine similarity in candidate stands. Candidates, knowing that many voters pay little heed to politics, seek support by publicizing their background characteristics, which reveal little about their competence or policy preferences" (pp. 239-40). He notes: "Race—but not religion or 
alma mater - is readily discernable by a glance at a campaign poster, brochure, or television ad" (p. 240). His conclusion from that point is that a voters decision to cast his or her ballot for a candidate of his or her own race "may be the result of reliance on a simple, readily available cue, much as a candidate's last name prompts some ethnically oriented voters to forsake party identification and support a fellow ethnic" (p. 240).

Reeves (1997), Taylor (1998), and Grofman et al. (1992) endorse the theory that increasing proportions of a minority group promote a distinct sense of ethnic threat to the power of the majority. He states that "the greater a district's racial composition tips in blacks' favor, the more inclined whites are to project the racial fears and anxieties they hold about blacks as a group onto an individual black office-seeker" (p. 101). This particularly true in those Southern states which have the highest Black proportions. As Bullock (1984) notes, in some communities in the South, "prejudice among whites and the desire for self-preservation by blacks produce almost total racial polarization at the ballot box" (p. 250). Reeves (1997) asserts that "were it not for predominantly black districts (which, parenthetically, are some of the most integrated election districts in the country), fewer black lawmakers would have been sent to Congress. This is especially so in the South" (pp. 95-96).

A rough examination of the effect of Black proportion on the willingness of Whites to vote for a Black candidate for higher office can be derived by examining data from the General Social Survey (GSS) which asks respondents, "If your party nominated a (Negro/Black/African-American) for President, would you vote for him if he were qualified for the job?" This question has the great advantage of having been asked in sixteen different administrations of the GSS over a twenty-four year period, from 1972 to 
1996, allowing for the analysis of the passage of time as a factor. There are, admittedly, several particular weaknesses presented by this question, which is the only question in the GSS which directly addresses the willingness of respondents to vote for a Black candidate for any office. For example, it is only asked regarding presidential candidates, which does not address the dynamic of local politics. The question also asserts that the Presidential candidate is the nominee of the respondent's own political party without specifying within that context whether the candidate shares some of the views which compel the respondent to affiliate with that party. The wide range of views expressed within each party make it is possible for a person to receive the nomination who may share very few positions with a given respondent. Another key problem is the possibility of some respondents giving the 'socially desirable' answer, and not being truthful. Although the number of respondents who indicated that they did not know whether they would vote for a Black presidential candidate was relatively small, Reeves (1997) provides plentiful anecdotal evidence to support his assertion that White voters who declare themselves 'undecided' when polled in an electoral contest between Black and White candidates eventually tend to vote in substantial proportion for the White candidate.

The following tables examine the relationship between the willingness of Whites to vote for a Black candidate for President nominated by their own party and a variety of other factors also derived from responses to the GSS. Age is measured in whole years, the youngest interviewees being 18 years old, with a range that trickles up to 89 . Education is also measured in whole years, ranging from 0 (indicating no formal education) to 20 (indicating $20+$ years of formal education). Political views are measured 
by the self identification of respondent's ideological orientation on a scale that ranges from 1 (extremely liberal) to 7 (extremely conservative). Because of the likelihood of overlap between ideological orientation and party identification, I chose only to use the former measure, which has the advantage of being an ordinal as opposed to a nominal variable. Similarly, I chose to exclude income, as the indicators for higher income tend to be captured in age and level of education.

Values for 'Black \% of region' were calculated by marrying the GSS data for the respondent's region of interview to the 1990 Census data for that region. Since only data from the 1990 Census was incorporated into this calculation, the question arises as to whether this is sufficient to gauge the influence of the Black proportion in a region for an interview conducted in 1972, for example. However, several sources indicate that although there has been a significant trend towards urbanization of the Black community from 1970 to the 1990 's, there have been only minor changes in the regional racial distribution of Americans, insufficient to upset the calculation (Kromkowski 2000; Lusane 1994; Meier and Rudwick 1976). 


\section{Table I.}

Descriptive Statistics for Independent Variables GSS data for Age, Education, Political Views, and Year

\begin{tabular}{lccc}
\hline & $N$ & Mean & S.D. \\
\hline Age & 18612 & 45.54 & 17.72 \\
Education & 18638 & 12.48 & 3.11 \\
Political Views & 15948 & 4.14 & 1.31 \\
\hline \multicolumn{3}{c}{ Median } \\
\hline Year & 17753 & 1983 \\
\hline
\end{tabular}

Source: General Social Survey

Table II.

Logistic Regression predicting willingness of Whites to vote for a Black candidate for President nominated by their own party.

\begin{tabular}{|c|c|c|c|c|c|c|}
\hline & \multicolumn{3}{|l|}{ Model 1} & \multicolumn{3}{|c|}{ Model 2} \\
\hline & Coef. & $\exp (b)$ & $S E$ & Coef. & $\exp (b)$ & $S E$ \\
\hline Constant & $2.416^{\mathrm{a}}$ & 11.197 & 0.052 & $-41.256^{\mathrm{a}}$ & 0.000 & 6.829 \\
\hline$\%$ Black & $-0.056^{\mathrm{a}}$ & 0.945 & 0.004 & $-0.050^{\mathrm{a}}$ & 0.951 & 0.004 \\
\hline Year & & & & $0.022^{\mathrm{a}}$ & 1.022 & 0.003 \\
\hline Age & & & & $-0.015^{\mathrm{a}}$ & 0.986 & 0.001 \\
\hline Education & & & & $0.143^{\mathrm{a}}$ & 1.153 & 0.008 \\
\hline Political Views & & & & $-0.106^{\mathrm{a}}$ & 0.900 & 0.019 \\
\hline Chi-square & & $250.479^{\mathrm{a}}$ & & & $724.663^{\mathrm{a}}$ & \\
\hline Cox \& Snell $\mathrm{R}^{2}$ & & 0.016 & & & 0.062 & \\
\hline Nagelkerke $\mathrm{R}^{2}$ & & 0.029 & & & 0.109 & \\
\hline$N$ & & 15202 & & & 15202 & \\
\hline
\end{tabular}

a. $\mathrm{p}<.01$

Source: General Social Survey 
As the results of Model 1 of the logistic regression indicate, the regional Black proportion does seem to have a small but statistically significant influence of -.056 on the willingness of Whites to vote for a Black presidential candidate, and by inference possibly for Black candidates for other high offices. In Model 2, the effect is only slightly reduced to -.050 when other factors are considered. However, both the level of education and the political views of the respondent have a more significant effect than the Black percentage of the region, in opposite directions. Each additional year of education makes the respondent approximately $15.3 \%$ more likely to be willing to vote for a Black candidate for President, while one notch along the ideological scale from liberal to conservative reduces the odds of a respondent holding this view by about $10 \%$.

The impact of Black regional proportion on the willingness of Whites to vote for a Black presidential candidate was relatively small, in keeping with the findings described by Taylor (1998) in her study of the same variable, which used GSS Primary Sampling Units instead of Census regions, and was therefore much more precise in the potential for measuring the effect of Black proportion on the community level as opposed to the regional level. Nevertheless, there is a startling parallel between the results of the logistic regression on the regional level, and Taylor's (1998) finding that "a 10-point rise in the local percentage of blacks is predicted to increase opposition to race-targeting [affirmative action measures, which were one of the key factors of her study] about as much as 3.3 more years of education would decrease it," (pp. 520-2) echoes my own finding that a 10-point increase in the regional percentage of Blacks is predicted to decrease willingness of Whites to vote for a Black presidential candidate by roughly the amount of increase in that willingness that would be seen with an additional 3.27 years of 
education. In the 1996 GSS survey, White acceptance of the possibility of supporting a Black presidential candidate surpassed $90 \%$ for the first time, and the overall trends indicates that as time passes and people tend to become more educated, there will be a continued positive movement in this direction.

Reeves (1997) and Grofman et al. (1992) both fault the media to some degree for the current inability of voters to overcome concerns about race. Grofman et al. (1992) express particular concern for appeals to voters to consider race as a factor in their evaluation of candidates. The authors assert that racial appeals "are present in a campaign if one candidate calls attention to the race of his or her opponent or opponent's supporters or if the media covering a campaign disproportionately call attention to the race of one candidate or of that candidate's supporters" (p. 107). Reeves (1997) examines the prevalence of such appeals, and comes to the following conclusion:

News media organizations... in their coverage of electoral competition between black and white political candidates, invariably promulgate the campaign in terms of racial-political conflict as it defines or impedes on campaign strategy and themes. Or journalists and editors, perhaps believing that they are simply reporting interesting aspects of the campaign and the candidates, make continual references to race, most often in the form of adjectives to describe the black office-seeker vis-à-vis his or her white opponent. Hence, given the norms and conventions of news organizations - the rewarding of messages that are dramatic, personal, concise, and visual and that take the form of narrative - race is treated as highly salient in the coverage of black candidates' campaigns, thereby making the task of attracting white electoral support... all the more difficult. (p. 23)

Reeves (1997) also asserts that the "contemporary tendency of whites to discriminate against black political candidates on account of race shows how little underlying attitudes have changed despite the significant gains made possible by the 
Voting Rights Act. As we have seen, equal political opportunity cannot possibly exist where the subtle fanning of racial appeals impels racially biased behavior inside the confines of the voting booth" (pp. 93-94 emphasis is author's own).

Frymer (1999) suggests that while overt racism has diminished, opposition by the majority group to issues that are of particular concern to minority communities is now hidden in ideological tones. He states: "Whereas in the 1800 s, racist ideology often transcended broader left-right political distinctions, since the 1960s the two have subtly blended together" (p. 87). Black and Black (1992) note: "Prejudicial feelings and conflicts of interest between whites and blacks can still be exploited in elections, especially when the appeal can be packaged in symbols or issues that have no explicit connection with race" (p. 7). Some Blacks have succeeded politically by carrying a conservative message that seems to oppose conventional Black political thinking, Reeves (1997) concedes: "Critics of race-conscious districting habitually point to the fact that black Republicans Gary Franks of Connecticut and J.C. Watts of Oklahoma won election from majority-white congressional jurisdictions in 1990 and 1994, respectively," but asserts that these candidates have been able to succeed in districts where blacks account for fewer than $6 \%$ of the population precisely because, "there is no sizable black constituency to moderate the black candidate's stance on race" (pp. 100-101). 


\section{Gains Earned and Lost in Recent Decades}

Black political power over the past several decades has been vested primarily in municipal officers and members of Congress, along with a variety of officials in nonelected positions, including some federal judges and Cabinet members. Majority-Black cities and counties have consistently elected Black mayors and council members, and through the control of those offices, Blacks have successfully sought the hiring of Black city/county managers, police chiefs, school superintendents, and other non-elected municipal officers. Some of the largest and most prominent cities in America-Atlanta, Baltimore, New Orleans, Detroit, and Washington D.C.- - have reached Black majorities and come under Black control. Majority-Black congressional districts, as mandated by the Department of Justice's interpretation of the Voting Rights Act, have given some security to Black members of Congress from Southern states with high Black proportions. At the same time, control over redistricting in Northern states by coalitions of Blacks and sympathetic White allies has led to the creation of several secure Black Congressional districts in the North.

Despite all of these gains, Blacks still lag far behind Whites in terms of proportional representation within elected bodies at all levels of government. The following table demonstrates how Blacks are under-represented in elected offices in the 20 states with the highest proportions of Black residents. The figures are garnered from the Joint Center for Political and Economic Studies, a private organization dedicated to tracking Black political and economic representation. 
Representation of Black Elected Officials compared With Black proportion of state population for the top 20 states with the highest Black proportions.

\begin{tabular}{|l|r|r|r|r|r|}
\hline \multicolumn{1}{|c|}{ STATE } & $\begin{array}{c}\text { U.S } \\
\text { Black }\end{array}$ & \multicolumn{1}{c|}{$\begin{array}{c}\text { U.S. } \\
\text { Reps }\end{array}$} & $\begin{array}{c}\text { State } \\
\text { Senators }\end{array}$ & $\begin{array}{c}\text { State } \\
\text { Reps. }\end{array}$ & $\begin{array}{c}\text { All } \\
\text { offices }\end{array}$ \\
\hline Mississippi & 36.620 & $25 \%$ & $19 \%$ & $29 \%$ & $19 \%$ \\
Louisiana & 32.856 & $14 \%$ & $23 \%$ & $21 \%$ & $14 \%$ \\
South Carolina & 29.933 & $17 \%$ & $15 \%$ & $21 \%$ & $14 \%$ \\
Georgia & 29.236 & $23 \%$ & $20 \%$ & $18 \%$ & $9 \%$ \\
Maryland & 28.793 & $25 \%$ & $19 \%$ & $21 \%$ & $8 \%$ \\
Alabama & 26.287 & $14 \%$ & $23 \%$ & $26 \%$ & $17 \%$ \\
North Carolina & 22.068 & $15 \%$ & $14 \%$ & $14 \%$ & $9 \%$ \\
Virginia & 20.360 & $9 \%$ & $13 \%$ & $10 \%$ & $8 \%$ \\
Delaware & 20.055 & $0 \%$ & $5 \%$ & $7 \%$ & $2 \%$ \\
New York & 17.043 & $14 \%$ & $10 \%$ & $14 \%$ & $1 \%$ \\
Tennessee & 16.757 & $13 \%$ & $9 \%$ & $13 \%$ & $3 \%$ \\
Arkansas & 15.978 & $0 \%$ & $9 \%$ & $12 \%$ & $6 \%$ \\
Illinois & 15.602 & $16 \%$ & $14 \%$ & $13 \%$ & $1 \%$ \\
Florida & 15.465 & $12 \%$ & $13 \%$ & $13 \%$ & $4 \%$ \\
Michigan & 14.837 & $13 \%$ & $13 \%$ & $14 \%$ & $2 \%$ \\
New Jersey & 14.401 & $8 \%$ & $10 \%$ & $14 \%$ & $3 \%$ \\
Ohio & 12.089 & $6 \%$ & $12 \%$ & $13 \%$ & $2 \%$ \\
Texas & 11.956 & $6 \%$ & $6 \%$ & $9 \%$ & $2 \%$ \\
Missouri & 11.713 & $13 \%$ & $12 \%$ & $8 \%$ & $1 \%$ \\
Pennsylvania & 10.497 & $5 \%$ & $6 \%$ & $7 \%$ & $1 \%$ \\
\hline
\end{tabular}

a. source: U.S. Census

b. includes all elected federal, state, county, and municipal offices at all levels within the state; depending on local practices, this may also include elected judges and school district officials

Source: Joint Center for Political and Economic Studies 
The preceding figures demonstrate that Blacks are particularly under-represented when all elected offices are taken into account. However, Bositas (2000), writing for the Joint Center for Political and Economic Studies, notes that there has been continuing improvement during the decades that the number of Black elected officials been tracked. Clayton (2000) argues that such improvement is the result of the success of race-based redistricting. He notes that "creation of majority-minority districts has helped increase the representation of African Americans at the congressional level. The CBC [Congressional Black Caucus], although representing a more diverse constituency than ever, still serves to protect the interests of black Americans. With the increase of $\mathrm{CBC}$ members to 38 , it has established itself as a formidable caucus now able to form coalitions with other informal groups in Congress. The CBC can help pass legislation critical to the black community: housing, education, unemployment, and crime" (p.22). Swain (1995) concurs with Clayton's assessment that redistricting has promoted substantive representation, noting that where "blacks have become more experienced in Congress, they have become more effective. Their ability to provide substantive representation for their constituents has increased with their understanding of the procedural rules of Congress: the amendment process, bill drafting, timing, and logrolling. Representatives who know the institutional rules of Congress have power far beyond their individual vote" (p. 44).

Clayton (2000) argues for a continuation of the existing strategy of creating and maintaining majority-Black congressional districts, stating that "the case for majority black congressional districts remains compelling" because of "continued residential segregation, the existence of racial-bloc voting on the part of whites, and lack of minority 
success absent race-conscious remedies,” (p. 4). Racially-conscious congressional redistricting efforts may have already approached the limits of increasing Black representation in Congress, however. As Swain (1995) concludes, "Black politicians are already representing all of the country's majority-black congressional districts, and after the 1992 elections relatively few areas remain where blacks are sufficiently concentrated for courts and state legislatures to create new districts." She concludes that in the future, "significant growth in the number of blacks in Congress cannot come from creating newly [majority-]black districts" (p. 207).

Municipal gains have also been consolidated, in some cases with great success. Stone and Pierannunzi (1997) describe how the sharing of power "in Atlanta's regime rests on the fact that African Americans have numbers and substantial voting power but limited economic resources. The business elite controls enormous economic resources but lacks numbers. That African Americans could supply needed numbers paved their way into incorporation initially, and as those numbers reached an electoral majority, they took on added weight" (p. 166). However, while businesses operating in Atlanta count on Black political support to some degree, "the white business elite has... made use of varied strategies to see that major parts of economic development activity would be insulated from city hall control. Therefore, while African Americans have achieved a strong form of electoral incorporation, their control is over a limited sphere of development - even though much of that activity is publicly subsidized" (p. 169).

Stone and Pierannunzi (1997) discuss the irony of Black leaders in Atlanta, who had once opposed the annexation of White suburbs for fear of losing political clout, now considering the annexation of such areas to improve the city's economic standing. "The 
tables had turned by the 1980s," they declare, "when several black leaders actively discussed annexation of Sandy Springs, an affluent white area just north of the city, whose acquisition would add a substantial tax base but not threaten Atlanta's status as a black-majority city" (p. 110). Examining the degree to which majority-Black status has increased Black control over their economic destiny, they conclude that "the incorporation of African Americans into the Atlanta regime amounts to more than electoral control of city hall. It extends into the business and civic life of the city, but this incorporation is limited. Business interests make key decisions in the privacy of the boardroom, not in the more racially inclusive circles of Atlanta's civic life" (p. 171).

Lusane (1994) discusses how in the 1970s, "Black mayors of big cities, by virtue of their high visibility and powerful positions, assumed national stature." He affirms, however, that the power of Black mayors is often limited by the structures and powers of their counties and states, stating that "more than half are located in small, majority Black towns of less than 2,000 residents-towns that are dependent on White-controlled county and state government bodies" (p. 23). Municipal Black majorities, therefore, may guarantee Blacks the opportunity to elect officials that represent their experience, but this does not necessarily guarantee that this political power will facilitate swift social or economic change. Whelan and Young (1991) note that even after New Orleans had become a majority-Black city, and had elected a Black mayor, that mayor had to take a nonelected governing board to court in order to secure positions for Black members ( $\mathrm{p}$. 139), and Perry (1997) reports that "blacks in Birmingham have clearly not achieved an equitable proportion of municipal employment commensurate with their approximately 
55 percent of the city's population," although he does allow that "they have made significant progress in increasing their representation in municipal employment" (p. 189).

Despite the gains that have been won, and the fact that segregation is no longer discussed as an option, there have been significant setbacks. Black mayors have also been elected in large cities without Black majorities, but these elections have not created opportunities for consistent Black representation. Browning et al (2000) note in discussing the loss of Black-held mayorships in Philadelphia, Chicago, Los Angeles and New York, for the people "who welcomed the growing political incorporation of African Americans as a solution to their unacceptable exclusion, these defeats have been sobering, to say the least. The defeats are real and the potential for further losses is not insignificant" (p. 134). Large Black populations in these cities guarantee that there issues will not be long ignored by any governing coalition, especially in cities where the Black population is expected to represent a continually increasing proportion of the whole. Glassberg (1991) says of St. Louis, for example, that "there is no reason to anticipate the development of a black voting majority anytime soon, but expectations that the city eventually will have such a majority play a major part in its politics” (pp. 86-7).

As in the post-Reconstruction period, many liberal Northern Whites have largely withdrawn from an active role in promoting Black equality. Indeed, opposition has developed among Northern Whites to policies such as affirmative action, characterized by White opponents as giving opportunities to Blacks by taking them from Whites. Feagin and Sikes (1994) declare: "government action to eradicate prejudice and discrimination has oscillated in recent decades. From the early 1980s into the 1990s African Americans experienced a conservative backlash against an aggressive expansion 
of civil rights and economic opportunities" (p. 322). At the same time, recent Supreme Court decisions have overturned the previous trend of decisions supporting the creation of electoral districts favorable to Black candidates. One Black scholar notes that "in a reversal of political momentum similar in some ways to that of the late part of last century, the Supreme Court under Chief Justice William Rehnquist began to pull the teeth out of laws designed to achieve racial equality" (Robinson, 1998). Feagin and Sikes (1994) claim that "major [U.S. Supreme Court] decisions in the mid- to late-1980s made it much harder for blacks to sue for redress for racial discrimination" (p. 323).

Clayton (2000) examines the position of the Court on enforcing Black opportunities for political participation and concludes the following:

Throughout the 1980s, the U.S. Supreme Court rendered decisions that were designed to provide a legal basis for blacks and other minorities to challenge tactics diluting minority voting strength. These decisions, coupled with a U.S. Justice Department's interpretation of the Voting Rights Act of 1965 and its subsequent amendments requiring the drawing of majority black districts by states where possible, created an environment in which blacks were not to be relegated to a permanent minority voting status. Today, much of that progress, along with majorityminority congressional districts, is being dismantled. (p. 130).

Many authors express similar pessimism in examining the prospects for Black social and political advancement of Black Americans. Lusane (1994) states that Blacks are not at all surprised to find that "racism continues to play a decisive role in the destiny and life chances of people of color in the United States" (p. 3), and Frymer (1999) echoes this concern, stating that even at the "end of the twentieth century, it is clear that racism and racial inequality will not disappear any time soon" (p. 206). 
Lusane (1994) expresses the belief that "the strategy of voter registration and voter turnout will likely remain predominant for the foreseeable future" (p. 35). Berry and Blassingame (1992), however, suggest that Blacks require a more active strategy to maintain their gains. Assessing the White withdrawal from active support for measures that improve the standing of the Black community, they write: "As blacks reflected on the strategies they might use to address political changes, they saw increasingly that direct action, protest, whether violent or nonviolent, was an essential ingredient of successful political action. But the political action did not improve the overall black condition. Even the new coalition-building politics had worked in the economic arena only to the extent that the goals did not require inordinate sacrifices on the part of any other members of the coalition" (p. 634).

While many of the methods of denying Blacks the right to vote and the right to be represented have been challenged and defeated under the authority of the Voting Rights Act, one key area in which Whites have been able to usurp the power of office thus acquired has been to change the powers of the offices themselves. Barker et al. note that in some Alabama counties, "many newly elected black officials in racially hostile jurisdictions previously controlled by whites have found themselves denied funds, equipment, information, or specific powers through new rule changes" (p. 83). Such actions have been determined by the Supreme Court to fall outside of the jurisdiction of the Voting Rights Act. Although they deprive Blacks of substantive representation, the Court has found that they are not directly related to the ability of Black voters to elect candidates of their choice. 


\section{The Inadequacy of Congressional Redistricting}

There are many problems with redistricting, both for local and federal offices, as a solution to the lack of Black representation. These problems hinder the usefulness of redistricting as a strategy for Black empowerment. Foremost among them is the disparity in the relative political power of such offices compared to that enjoyed by those elected to statewide offices, the attainment of which can not be aided through any redistricting process. The short history of the redistricting process has proven that Black communities seeking Congressional representation commensurate with their proportion within a state may be forced to expend significant resources on lengthy court battles to achieve satisfaction. In the case of North Carolina in the 1990s, for example, litigation over Congressional redistricting initiated in 1991 stretched into the middle of 1993 (Canon, 2000). Louisiana "had three sets of congressional district lines based on the 1990 Census" (Barone et al., 2002, p. 667), the final version having been drafted by a federal court in January of 1996, and then approved by the Supreme Court in June of that year.

Congressional redistricting designed to empower the Black minority in states with large Black populations has proven to be susceptible to manipulation by elements of the White majority. Canon (2000), Hill (1995), and Swain (1995) describe how Republicans have sought to use this process to remove highly Democratic Black voters from districts where they have traditionally helped White Democrats succeed electorally. Hill (1995) notes that, after the creation of majority-Black districts in Southern states, "majority white districts in the South now have an average proportion of $11.3 \%$ black voters, with a $7.5 \%$ standard deviation, down from 1990's $16.3 \%$ average with a $10 \%$ standard 
deviation. Thus, not only are the majority white districts less black, they are also more uniformly less black" (p. 386). He arrives at the determination that "the Republicans made significant gains in the South in 1992, many of which were attributable to the creation of majority black districts" (p. 391-2). These Republican gains are no accident of circumstance, as Hill (1995) concludes that an examination of these circumstances bolsters the suspicions of "those claiming that the Republican Justice Department was intentionally packing blacks into districts at as high a rate as possible" (p. 400) in order to maximize Republican gains among the remaining districts.

Swain (1995) also criticizes the facility with which majority-minority districts can be manipulated for the benefit of the majority group, and she discusses the specific means by which this is done. She explains: "Racial gerrymandering occurs when district lines are drawn to enhance or reduce representation of particular racial groups. Its major forms are known as 'cracking' (a significant minority population is dispersed across several districts to dilute its voting strength), 'stacking' (large concentrations of minority voters are combined with white populations to create districts with white majorities), and 'packing' (minority voters are put in districts that already have high minority populations)" (p. 197). Grofman et al. (1992) note that "as a matter of practical reality, the minority district(s) that will be drawn are districts centered in the heavily minority areas of the jurisdiction" (p. 104), and Baker (2001) concludes that "creation of majorityminority districts... has also been criticized by scholars who point out, for example, that few new African-American members will be produced by the practice of packing as many black voters as possible into a district. The limit of such districts has been reached" (p. 111). 
Swain (1995) also explains that "Black politicians consider packing less harmful than the other two forms of racial gerrymandering, because it adds to the safeness of their districts... Only a minority of black politicians oppose the packing of black votes" ( $\mathrm{p}$. 198). However, she makes the point that even some Black politicians are wary of the hazards inherent to this strategy, noting that "Representative Craig Washington, a Texas Democrat... argues that isolating black voters in overwhelmingly black districts places them in a situation where their policy preferences can be more easily ignored" (p. 198). Baker suggests that this isolation of Black politicians in majority-minority districts can further diminish their opportunities to attain higher office. He states that avenues of advancement to statewide office for black House members [are] impeded because those from majority-minority districts will have had little exposure to white voters whose votes they would need to win, for example, a seat in the U.S. Senate" (p. 111).

Perhaps the greatest failing in the strategy of redistricting is the innate instability of the process. In accordance with Article I, Section 2, Clause 3 of the U.S. Constitution, congressional redistricting is undertaken after every decennial Census. The process is controlled by the individual states, generally by the legislature of each state (although a few states have established non-partisan committees to conduct this responsibility). State legislatures are themselves unstable bodies subject to the whims of the voters in their composition and containing individuals with complex and changeable motivations. Most importantly to the interests of Blacks, all state legislatures have White majorities, limiting Blacks power to influence redistricting decisions. Hence, every ten years, a group of mostly-White legislators seek to redraw the congressional districts of that state to suit whatever the interests of the majority party in that legislature appear to be at that time. 


\section{Relative Political Power in Elected Offices}

How important is the lack of representation of Blacks among Governors and Senators? Of over 9,000 Blacks holding elected office as of 2001 (Joint Center, 2001), none is in either the United States Senate or a Governor's seat. The numbers of Representatives are below the general proportion of Blacks in America, and since all but one are Democrats, the shift to the Republican control of Congress in 1994 has undermined the power of Black Representatives within that body. Grofman et al. (1992) note that as of 1990 , "approximately 5.4 percent of state legislators and 1.5 percent of all elected officials were black, compared with 11.1 percent of the voting age population" ( $\mathrm{p}$. 138). The most striking area in which Blacks lack representation is in the United States Senate and in governorships.

There are currently no Black senators or governors, and in fact, Kiely (2002) points out that out of " 1,864 people who have served in the Senate since 1789,15 have been minorities: four blacks (two elected), three Hispanics, four Asian-Americans, three Native Americans and one Native Hawaiian. More than 2,200 people have served as governors. Nine have been minorities: four Hispanics, three Asian-Americans, one black and one Native Hawaiian" (emphasis added). These figures, of course, must be understood in the context of several important facts. The first is that Blacks were essentially barred from holding any elected office prior to the Civil War. The second is that for most of this nation's history, members of the U.S. Senate were appointed by the legislatures of the states from which they hailed, and were not popularly elected until 1913, pursuant to the $17^{\text {th }}$ Amendment to the U.S. Constitution. 
Nevertheless, the lack of Black representation in these offices even since the passage of the $17^{\text {th }}$ Amendment is more than a symbolic slight. Baker (2001) and Lee and Oppenheimer (1999) demonstrate how the nature and structure of the Senate as compared with the House of Representatives make the former body vitally important to the direction of national policy. It can therefore be demonstrated that the lack of consistent Black representation in the United States Senate handicaps the substantive political power of African Americans. The significant difference in the level of power exercised by a member of the House as compared to a member of the Senate is based both on elements inherent to these institutions - particularly the size, the distribution of seats, and the length of the term of office-and on the development of the rules under which each body has chosen to operate.

Of the powers specifically reserved to the Senate, probably the most important to the Black community is the Senate's ability to confirm or deny the appointment of federal judges, including the Justices of the United States Supreme Court. Barker et al. (1995) note that Blacks are currently under-represented on all levels of the federal judiciary, including District Courts and the U.S. Court of Appeals (pp. 118-20). They assert that "the fact that there are still so few black judges is yet another example of the disproportionate representation and influence of blacks in the American political system" (p. 120). Lusane (1994) argues the importance of this circumstance to the Black community, stating that "Supreme Court nominations have immense relevance to African Americans. Critical Supreme Court decisions in the last century, most notably the Dred Scott decision (1857) and Plessy v. Ferguson (1896), determined the destiny of millions 
of African Americans and codified into law and policy the mass repression and neoenslavement of blacks" (p. 75).

With only 100 members compared to the 435 in the House, an individual Senator has 4.35 times as much voting power within his or her legislative body as an individual member of the House. Even if the disparities ended there, the election of a single Senator would still carry more weight in the Capitol as the election of four Representatives. Lee and Oppenheimer (1999) note that the Senate as an individual body of government "is coequal with the House of Representatives in all powers of legislation, even possessing some powers not granted to the House, the most important being the right to approve presidential appointments and treaties" (p. 2). Institutional rules give Senators additional leverage within the Senate above and beyond the difference in power accorded by their numbers. Baker (2001) notes that "rules of procedure that are promoted by the Senate's smallness magnify the influence of the individual by allowing a single senator to intervene - often decisively - in the legislative process. Power of this magnitude is accorded to only a handful of the top leaders in the House" (p. 73). He quotes former Senator and former House member John Culver: "The rules of the Senate are congenial to permitting the least consequential member to shut it down if he's smart enough or willful enough to do it. If you're one in a hundred, it really doesn't matter a lot how long you've been there. That gives any individual power - real power - in institutional terms" (p. 72).

Another area where the Senate gives its members increased power relative to the House is in the process of attaching amendments to bills. Baker (2001) explains that "House rules require that amendments to a bill made on the floor must be germane, that is, relevant and pertinent to the bill itself. With certain exceptions, senators can introduce 
floor amendments that have nothing at all to do with the bill as it comes to the floor from a committee" (p. 76). This is significant because it gives members of the Senate the ability to force fellow Senators to take specific positions on issues. As Baker (2001) notes: "Because they are able to introduce amendments on the floor virtually at will, any senator can demand a recorded vote of his colleagues at almost any time" (p. 78). Senators, however, generally do have more room to take unpopular stances on specific issues, because most represent much larger constituencies than Representatives. Baker (2001) says that "House members, who lack any statewide constituencies, often represent fewer interests and any given interest is likely to loom more imposingly in a House member's calculations than that of a single interest in a large, complex state” (p. 50).

Procedurally, Baker (2001) notes that the Senate "is a shrine to the rights of the political minority and its rules confer considerable power on it to thwart the will of the majority" (p. 102). Lee and Oppenheimer (1999), however, discuss how the apportionment of the Senate actually harms the representation of ethnic minorities. They note, first and foremost, that Senate apportionment causes small states to be vastly overrepresented, noting:

Wyoming, with fewer than half a million residents, enjoys the same level of representation as California, with more than 30 million. More than a quarter of the United States population now lives in three very large, rapidly growing states (California, Texas, and Florida), yet they are represented by only six senators. A mere 7 percent of the total United States population, on the other hand, resides in the seventeen least populous states and is thus represented by thirty-four senators. (p. 2).

Because of this disparity, Lee and Oppenheimer (1997) argue that "Senate apportionment works contrary to the purpose of protecting minorities. ... race has become 
so important in American politics that today the term 'minority' is almost synonymous with racial and ethnic minorities. Instead of ensuring that these minorities receive additional representational weight, Senate apportionment has the effect (albeit unintentional) of diluting their influence" (pp. 20-21). This outcome, they argue, occurs "because the states with smaller populations also tend to be less ethnically and racially diverse than the nation as a whole" (p. 21). Lee and Oppenheimer (1999) state that in "the thirty-one over-represented states, blacks on average account for only 7.5 percent of the population; by contrast, in the fourteen underrepresented states blacks average 14.3 percent" (p. 22). They further elucidate their argument by contrasting the proportion of African Americans throughout the nation with the proportion found in the median state, concluding that "the median state is in every case less racially diverse than the nation as a whole. For instance, although blacks account for 12.5 percent of the nation's total population, the median state has a population that is only 7.1 percent black" (p. 22).

The political power of Blacks in influencing the election of Senators is further reduced by the particular politics of many of the states in which Blacks tend to reside in large numbers. In Southern states, which generally have the highest Black proportions, White majorities present a sufficiently solid block of votes to override the strength of the Black vote and elect more conservative candidates. Therefore, the concern of members elected to the Senate is not in representing the interests of the Black minority, but in maintaining the solid base of support from the White majority. In Northern states with relatively high Black proportions, the more liberal tendencies of White voters in these states tend to make the Black vote superfluous in the election of liberal candidates. Blacks are important swing voters crucial to the victory of a candidate in only a handful 
of states, such as Michigan, Illinois, Ohio and Missouri, and even in these states they are not always successful in determining the outcome of an election.

Stone and Pierannunzi (1997) underline the importance of majority-Black governance in achieving desired policy aims. In Atlanta, they note, electoral "mobilization was a key element in black incorporation, and incorporation as a voting majority was central to the ability of the black community to achieve significant policy responsiveness. Clearly elections matter, and majority voting pays real dividends in governmental decisions" (p. 165). Barker et al. (1999) agree with this sentiment, noting that in Alabama the "election of black legislators represented a significant increase in black political empowerment" (pp. 81-82). Given the superior political power of members of the United States Senate, the election of Black senators could be expected to pay similar dividends at the federal level. The lack of Black senators, therefore, is a great blow to the ambitions of the Black society in America.

\section{Governmental Elements Derived From the State as a Political Unit}

The state, as a political unit, has a number of attributes which make it politically attractive compared to the smaller units contained within, such as cities, counties, and congressional districts. As previously noted, governors and senators are universally elected statewide, and a majority group within the state has the ability to control these elections with no support from members of any minority group. Majority groups control the election of a majority of the members of the State legislature, and with the exception 
of Hawaii (which is anomalous in many respects) every state legislature in the United States does have a majority-White legislature. Most state governments also play some role in the appointment of their state's highest judicial body, although many states have elected judges. In either case, the majority of the population will directly or indirectly influence how judiciary positions are filled.

Each state has its own constitution, which defines and circumscribes the powers of its government. While it is technically possible for states to arrange their governments according to non-convention formulas, every state has chosen to establish legislative, executive, and judicial branches, which roughly parallel those of the federal government. In every case, the chief executive of the state is the governor of that state, although some governors are essentially figureheads, with little real power to affect policy without the consent of an elected cabinet or another branch. Others, however, have fairly extensive powers to direct political activities within their states, and the powers of the governor can be increased or reduced through changes in the constitution of a given state. Ardleigh (2002) notes that governors have influence that extends beyond the borders of their home state, as she asserts that "governor's races are important to the national parties because governors are influential in the shaping of national policies on such issues as welfare reform, education and taxes." In addition, four out of the last five Presidents of the United States have been elected as sitting governors, demonstrating that this office is an effective stepping stone to even higher ambitions.

The amount of power accorded to state governments depends largely on the geographic and historic resources within the state. Individual state constitutions vary widely in the allocation of powers of the state to governors, state legislatures, other 
elected or appointed offices within the state government, and in the amount of control that state governments are able to exercise over counties and municipalities within the state. In most states, however, the constitution may be amended through referenda initiated by petition and supported by a vote of the majority of the population, which can effectively rewrite any of these elements. However the state may choose to divide up its authority to control different aspects of the governing process, there are certain powers granted by the federal government to the state as a unit that give the state critical control over the effective political representation of minorities residing therein.

As previously noted, states control their own redistricting process, which can be manipulated for the gain of the political party in control of the legislature. Clayton (2000) declares that redistricting "has always been about power. As a process, it has always been controlled by the majority party in the state legislature. In the twentiethcentury South, this has almost always meant that Democrats, who were usually in the majority, would draw district boundaries to the disadvantage of Republicans. Moreover, Democrats, the majority of whom were white, would also normally draw boundaries that diluted black voting strength — even that of black Democrats - by not creating majority black districts" (p. 3). According to Hill (1995) and Swain (1995), this situation has changed course over the past decade or so, as Republicans have sought to maximize their advantage in Southern states by creating overwhelmingly Black districts, thus reducing Black influence on the remaining White districts.

The state also has some limited power to determine election laws and residency requirements, although much of that authority has been overtaken by the federal government. For example, states were once able to set whatever residency requirements 
they desired, and Southern states used this capacity as a means by which to disenfranchise Blacks. However, Grofman et al. (1992) note that the "1970 [voting rights] legislation... standardized residency requirements by placing a ban on state residency requirements for federal elections of more than thirty days" (p. 19).

Felony Disenfranchisement:

One area where states still have broad discretion over the ability of persons to vote is in the disenfranchisement of felons and ex-felons. The Constitution of the United States allows individual states to determine if persons residing therein, having been convicted of a felony, shall be declared ineligible to vote. The laws regarding disenfranchisement due to felony convictions vary widely from state to state. Two states-Maine and Vermont-do not disenfranchise felons at all, even while they are serving prison sentences. On the other end of the spectrum, eight states-Alabama, Florida, Iowa, Kentucky, Mississippi, Nevada, Virginia, and Wyoming-disenfranchise convicted felons for life, even after they have served their sentence and any period of probation or parole. Other states fall in between these extremes, almost all revoking the right to vote for those who are serving prison sentences, and most removing this right from those persons on probation or on parole. A handful of states restore the right to vote or make it possible to be regained through a convoluted application process after a period of several years following the end of the individual's sentence.

In every case, however, the proportion of African Americans thus disenfranchised vastly outweighs the proportion of Whites. In those states that disenfranchise felons, the 
average statewide proportion of disenfranchised Blacks is approximately eight times the proportion of disenfranchised Whites (The Sentencing Project, 2002). The Sentencing Project (2002) notes, in fact, that in seven of the states which disenfranchise ex-felons, "one in four black men is permanently disenfranchised" (italics are original). Human Rights Watch (2000) reports that Florida disenfranchises a particularly overwhelming number of African Americans. As of the year 2000, they state that among "Florida's African American residents, the impact of the state's disenfranchisement laws is particularly dramatic: $31.2 \%$ of black men in Florida -- more than 200,000 potential black voters -- were excluded from the polls."

Supremacy of State Law Over Municipalities:

Control of counties and municipalities may give minorities the opportunity to make decisions regarding local issues, but only to the degree that the state government is willing to allow them such power. Stone and Pierannunzi (1997) note that the majorityWhite state government of Georgia has control over some key elements of civic policy in the majority-Black city of Atlanta, stating that agencies of the state, "such as the department of transportation, make critical decisions... without much voice from Atlanta's[Black] leaders" (p. 171). The earlier discussion of the revocation of powers held by Black elected officials in Alabama examined by Barker et al. (1995) is another example of the ability of the state government to interfere with the operations of municipalities therein. 
In fact, there are countless opportunities for a state government to influence the fortunes of cities and counties. Fleischmann (2000) summarizing the findings of David Rusk, notes for example that "state annexation laws and suburban incorporations leave inelastic cities unable to expand and thus surrounded in metropolitan areas fragmented into numerous municipalities" (p. 110). He goes on to state that "as minority residents and their influence increase, the inelastic cities over which they gain control may represent an ever-diminishing share of their metropolitan areas. Indeed, they may preside over the city's downward economic spiral and be desperate to secure private sector investment" (p. 115). In some cases, cities are forced by financial circumstances to turn to the state for support, giving the state additional leverage. According to Fleischmann (2000): "An increased role for state governments in regional issues may bring mixed results for minorities. Given the growing differences between Democratic cities and Republican suburbs, turning to the states as Rusk suggests may involve not only racial, but partisan, disputes" (p. 125).

State governments derive revenue from various sources, such as income taxes, property taxes, and fees for various licenses. This revenue is then reallocated according to the desires of the state legislature, through a process that generally reflects the political preferences of the party in the majority. The power to assess and reallocate revenues is a powerful tool in the hands of the legislature and the governor, as is the ability to confer this power to municipalities. The denial of needed funds can frustrate the plans of even the most well-organized municipal government. On the other hand, access to state funds combined with laws granting the ability to raise revenues independently can greatly advance the fortunes of a city or county 
Control of Electoral Votes:

Black and Black (1992) assert that "because presidential elections are won by carrying states, all of which adhere to the norm of 'winner takes all' in assigning electoral votes to the winning party, the state is the critical political unit in presidential politics" (p. 11). States also play a similar role in the process by which the parties nominate presidential candidates, although this process is complicated by various factors. Primary rules differ from state to state, some awarding delegates through proportional systems and others using the same 'winner takes all' model that drives electoral politics. Candidates also have more power in this process, as they may release their delegates when it is clear that their campaign has become a lost cause, or they may pledge their delegates to another candidate.

Barker et al (1999) note that, because of the nature of the electoral process, "the potential political power of a group is enhanced if its population is strategically distributed such that it can influence election results in the larger states... the size and distribution of the black population could give the black community a strategic voice in these areas, and by extension, significant national political influence" (p. 22). Berry and Blassingame (1992) echo this sentiment, suggesting that the current distribution of African American voters could be advantageous. They state that the "structure of the electoral college and the concentration of black voters in key states provided opportunities for blacks to exercise leverage in a presidential election" (p. 632).

However, Frymer (1999) demonstrates how the Black minority can, in every instance, be over-ruled by the White majority. He emphasizes as an example "the 
national election [of 1984], Walter Mondale received more than 90 percent of the black vote, but received only one-third of the white vote. Despite providing sizable minorities of the vote in the South, black voters were unable to help Mondale win a single state in the region... Contrary to the conventional wisdom that electoral groups benefit from their concentrated numbers in key electoral college states, the influence of black voters over the electorate did not increase in states where their numbers were highest" (pp. 111-2). The only guarantee, therefore, of Black voters controlling the assignment of the electoral votes of their state would be for Black voters to be the majority of voters in the state. 


\section{CHAPTER III.}

\section{Examining a Possible Solution}

The essential problem posed in the first two chapters is that of restoring what has been taken from Black Americans through generations of slavery, decades of legally sanctioned oppression, and continued discrimination: the sense of equal standing with all other groups with whom they share this country. The current population of the United States is roughly $281,421,000$ people, of which approximately $36,419,000$, or $12.94 \%$, are Black. In a truly color-blind nation, where all citizens had equal access to education and economic and political opportunities, it would follow that an equal proportion of elected officials would be Black. It would stand to reason, therefore, that there ought to be twelve or thirteen Black senators, at least a half-dozen Black governors, and about fifty-six Black congressmen, but none of these numbers are approached.

There are many possible responses to discrimination, including relocation. In theory, if the members of the Black population were to relocate themselves in careful accordance with the population of the United States, it would be possible to establish a majority-Black population in more than twenty states, and capture the gubernatorial, senatorial, and electoral authority among them. However, the logistical and economic problems posed by such an extreme program of relocation would make such an effort wholly implausible. A far more plausible alternative would be for Black leaders to create a movement focused on a single state, or a small group of states, and engineer the relocation of a sufficient number of Black families to create a Black majority in the designated state or states, which I will hereafter refer to as the 'settlement strategy.' 


\section{Majority and Minority Group Strategies}

There are two distinct dynamics inherent to the relationship between a minority group and the majority group within a given society. First, there are a number of strategies which members of a minority group may choose to employ in order to cope with their minority status. Individuals within a group may employ different strategies, but there will likely be a particular strategy which tends to dominate the group's approach to their situation. Second, and at the same time, members of the majority group will employ their own set of strategies to deal with the presence of the minority group. Feagin and Sikes (1994) state that from "the beginning of slavery African Americans have gone beyond individual strategies to consider what they as a group should be doing to deal with external racism and its internal effects on black communities. Among middle-class black men and women today one still finds a recurring concern with community and collective action" (p. 346). This analysis indicates that there is a particularly strong cohesion among African Americans, which is to be expected of a group that has been collectively subjected to an extended period of social traumatization.

Robertson (1987) identifies six basic strategies which a majority group is likely to follow in dealing with a minority presence. These are: pluralism; distinct legal protection of the minority group; assimilation; population transference or exile; subjugation; and extermination. The practice of pluralism embodies the acceptance by the majority group of the minority group within their midst, without efforts to assimilate or subjugate the minority. While this approach is often purported to be the American ideal, the current status of Blacks in America is the second, distinct legal protection, which is afforded in 
response to continuing racism in American society. Robertson notes that assimilation can be voluntary or forced, but fails to distinguish encouraged assimilation from forced assimilation as separate strategies. As has been previously noted, Blacks have generally chosen to resist complete assimilation, preferring to maintain their ethnic identity. At the same time, those Blacks who have made the effort to attempt to assimilate have often found themselves blocked by Whites unwilling to afford them this entry. The schemes to resettle freed slaves in Africa, Panama, or Haiti would have constituted population transfer, had they been carried out. Prior to the Civil War, Blacks in the South were formally and completely subjugated, while those in the North were subjugated to some degree in their treatment as inferiors.

Lavender (1999) identifies eight basic strategies by which members of a minority group can deal with their minority status. These are self-hatred; self-segregation or ghettoization; stigma redemption; covering (temporary passing); passing (permanent), which is akin to assimilation; correction; stigma conversion; and confrontation (pp. 31517). These definitions are not specific to ethnic minorities, but are also intended to apply to persons who are stigmatized in some way by some elements of society. Some of these responses are available to Blacks and used readily. One example is stigma conversion, which is the changing of a 'bad' attribute into good by using it in a positive sense, as embodied by the Black pride movement of the 1960s, which produced the motto, 'Black is Beautiful.' Other strategies available to Blacks in general include self-segregation, self-hatred, confrontation, and stigma redemption, which is a spiritual approach in which the minority group member accepts bad treatment in 'this' world, believing that they will 
be rewarded in the 'next' world for being a good person, despite the bad treatment which they have received.

The strategies of passing and covering can only be applied to the degree that individual members of the minority group are physically able to convince others that they are actually member of the majority group, which is rarely an option for those with discernable Black ancestry. Stigma correction, in which a member of a minority group accepts the larger society's definition of his or her status as being 'bad' and changes that associated behavior in order to be accepted, is also not available to Blacks. It is possible for an individual to change his or her behavior, and some minorities do attempt to adopt the culture of the majority group in order to increase their individual opportunities for success. However, it is nearly impossible for an individual to 'correct' the fact of their physical appearance, particularly when the physical attributes of the majority and minority groups are so distinctly different. No amount of behavioral change can protect a person who is Black from being categorized as Black by a White person who intends to use that classification as a basis for discrimination.

Members of an ethnic minority may turn to the extreme end of self-segregation, which is relocation, the complete abandonment of the majority society by the minority group. Lavender (1999) notes that "some activists have called for ghettoization on a larger scale by supporting, for example, an all-black state or nation" (p. 316). Meier and Rudwick (1976) describe the history of Black responses to the sense of oppression inherent in their situation as "ranging along a continuum of ideologies from assimilation to nationalism. At one end of this continuum have been the advocates of complete biological amalgamation and cultural assimilation with members of the dominant society, 
and the complete disappearance of blacks as a racial group. At the other end have been those who advocated complete withdrawal from American society and the creation of independent Negro states" (pp. 118-9). Lusane (1994), however, suggests that the current strategy of the Black community in general includes a particular focus on gaining power through holding elected offices. He states: "Unlike many Black radicals of the 1960s, the current group [of Black activists] sees political and tactical value of electoral politics... the new radical leaders recognize that to engage in electoral politics does not mean an abandonment of non-electoral struggles and strategies" (p. 39). Lusane (1994) does recognize, however, that "the conditions of the masses of Black make it clear that just putting African Americans in office is no guarantee of social progress... it can be argued that just to focus on electing Blacks diverts financial resources, time, leadership skills, and energy from developing strategies that, in the end, will be more beneficial to the Black community in the long run" (p. 35).

Migration is not discussed as a large scale strategy, but a closer examination of Black migration patterns in this century yields a different understanding. As has been previously noted, the massive Black migration from the South to the North at the beginning of the $20^{\text {th }}$ Century was an effort (albeit uncoordinated) to escape the fervent racism of the South. The current return migration from North to South, which will be discussed in greater detail in this chapter, is motivated in part by urban Blacks seeking to escape the poverty and degradation of the Northern inner cities. 


\section{Other Cases of State Control by Minority Groups}

There are some previous examples of minority groups exercising the power of control over a state government to their own benefit. In fact, there is one distinct example of a minority group engaging in a mass relocation quite similar to the strategy under examination here, in order to secure the political benefits of statehood. This can be found in the case of the Mormon migration to and settlement in Utah. The Mormons, as members of the Church of Jesus Christ of Latter-Day Saints are commonly known, are a religious order which was founded in 1830. Their founder was a farmer in New York named Joseph Smith, who claimed to have discovered new additions to the scriptures, and to have been designated as a prophet by an angel name Moroni. Barone et al. (2002) explain that the group "attracted thousands of converts and created their own communities; persecuted for their beliefs, they moved west to Ohio, Missouri and then Illinois" (p. 1521). Shortly after announcing a revelation that endorsed the practice of polygamy, Joseph Smith was murdered by a mob in the Mormon settlement of Nauvoo, Illinois, in 1844. The next Mormon leader, Brigham Young, responded in 1847 by initiating a "well-organized march across the Great Plains and into the Rocky Mountains" (Barone et al., 2002, p. 1521). Once there, Young and his followers settled in a part of the United States that was, at that time, still part of a vast and unincorporated territory.

Once the Mormons had established a sufficiently large population, they lobbied for statehood in 1849. "The object of religious fear and prejudice," Barone et al. (2002) write, "Utah was not granted statehood until 1896, after the church renounced polygamy" (p. 1521). Since that time, every governor, senator, and representative elected from Utah 
has been a Mormon, as have a sizable majority of the members of the state legislature. Mormons have also routinely been elected to the Senate from several surrounding states, giving that group a vastly over-representative presence in the Senate. Currently there are five Mormon Senators - including two from Utah, and each from Idaho, Nevada, and Oregon-coming from a group with a population of roughly 5.5 million members, or slightly less than $2 \%$ of the U.S. population. Barone et al. (2002) note that, consistent with conservative Mormon social views, Utah has been one of the most solidly Republican states in every presidential election since 1968.

Hawaii is another state where minority-majority status has yielded consistent representation by members of two groups which are nationally considered to be minorities, but which exercise a controlling majority in one state. With one early exception, Hawaii has sent only Asians and native Hawaiians to the U.S. Senate since it was granted statehood, in 1959. These senators have consistently been liberal Democrats, and Hawaii's electoral votes have gone to Democrats in all but two presidential elections. This liberal political history reflects what Barone et al. (2002) refer to as "a certain Polynesian attitude toward life" (p. 465), which is embodied in "a heritage of tolerance and openness to cultural diversity second to none" (p. 467). Barone et al. (2002) maintain that "it was Hawaii's super-American tolerance that inspired segregationist Southern Democrats to block its admission to the Union for years" (pp. 465-66). In relation to the strategy discussed in this thesis, however, it is important to note that Hawaii has always had a majority non-White population. 


\section{Can it be done?}

The establishment of a majority-Black state has been suggested before, and has even been attempted at least once. To be fair then, a critic of this strategy might ask why it might succeed now when it has failed in the past. The answer lies largely in the changes that have occurred in society particularly over the past few decades. At the time of Edwin McCabe's doomed effort, it was entirely possible for Whites to develop schemes by which they could deprive Blacks of the right to vote. Because Blacks generally had not previously been granted this right, denying them access to it was socially acceptable behavior.

In this era, a generation after the passage of the Voting Rights Act, Blacks and Whites alike are accustomed to the idea that people should be and will be allowed to vote. The vast majority of Blacks who wish to vote in this country are now able to do so unhindered, despite minor incidents such as overzealous purging of ex-felons from the voter rolls, which tends to affect a higher proportion of Blacks than Whites. Similarly, it is now generally understood that Blacks can move where they wish, and can not overtly be prevented from living in a particular neighborhood, and certainly can not be hindered from moving into a particular state.

Another factor that points to an increased chance of success is the availability of resources. At the time of McCabe's migration, almost all Blacks had only recently been emancipated from slavery, and most had virtually no money and few possessions. There was only a very tiny Black middle class of artisans and professionals, and certainly no Blacks were among the upper-echelons of the very wealthy. Despite the fact that 
modern-day Blacks, on the average, still have less wealth than members of other ethnic groups, the Black community today has access to more financial resources than ever before. There exists a solid Black middle class, and some Black athletes and entertainers have achieved truly phenomenal wealth, and have demonstrated their willingness to direct some of there towards the betterment of the Black community, although these efforts are usually very localized. A number of institutional resources could be used in the implementation of the settlement strategy. Black-owned businesses and similar economic institutions could work towards financing this strategy and could focus on establishing jobs in the target state and expanding of economic opportunities in existing majority-Black areas within that state. Black churches and historically Black colleges and universities could serve as important points of communication and coordination, as they have often done in past Black social movements. The exact degree to which each of these resources would be able to contribute to a settlement movement is yet another topic which could be richly examined in future research.

The concept of establishing a majority-Black state is not entirely unknown to modern Black leaders. This idea has, in fact been advocated in recent decades, to be achieved not through settlement, but by the granting of statehood to the District of Columbia. Swain (1995) describes how the Congressional Black Caucus "has for a long time pursued statehood for the District of Columbia, and this goal is related to the pursuit of higher office by blacks. If the District is granted its statehood, blacks will have a chance to attain... governorship and two senatorial seats" (p. 221). This strategy, however, would rely on the cooperation of White supporters, as the change in status of a district or territory requires the consent of the U.S. Congress. Ardent promotion of this 
goal has met with failure, which further indicates that African Americans seeking consistent representation in the Senate and among the state governors may need to rely on the settlement strategy. In order to determine whether such a strategy is feasible, it is first necessary to determine exactly how many people would have to move from one state to another, how far they would have to move, and if it is likely that enough people would be willing to make such a move.

\section{Calculating the Differential by State}

In order to figure out how many Black immigrants a state would need to absorb in order to attain majority-Black status, it is first necessary to settle the issue of who exactly is Black. One dilemma that presented itself in interpreting the 2000 Census was a change-albeit one that makes the data more reflective of reality-in the classifications offered by the Census itself. In previous administrations, respondents were required to select one race, including the choices of 'White' and 'Black, African American, or Negro,' which we will simply call 'Black.' In the 2000 Census, however, respondents were allowed for the first time to select as many races as apply to them, leading to a disparity between those who only indicated that they were Black and those who merely included this classification as one of several choices. For the purposes of this paper, respondents who only indicated that they were Black will henceforth be referred to as 'Black Only,' while those who indicated Black in combination with anything else will be referred to as 'Mixed Black.' The total population of respondents who indicated that they 
were any part Black, including all who indicated Black Only and Mixed Black will be referred to as 'Black Any,' and general reference to Blacks will indicate this complete group as well, unless otherwise noted.

According to the Bureau of the Census, "the most common combinations were 'Black and White' (45 percent), followed by 'Black and Some Other Race' (24 percent), 'Black and American Indian and Alaskan Native' (10 percent), and 'Black and White and American Indian and Alaskan Native' (6 percent)" (McKinnon, 2001). There are four primary scenarios for individuals choosing to categorize themselves as mixed. Either they had categorized themselves as Black in the previous Census, and are using the new allowances of the current Census to indicate a heretofore undenoted mixture in their ancestry; or they had categorized themselves as something other than Black in the previous Census, and are now taking the opportunity to acknowledge their Black ancestry; or they were not old enough to fill out the Census form in 1990, and their racial category was selected by the parent or parents who filled out the form on their behalf; or they were born after 1990, and have been listed for the first time as being of mixed race by the parent or parents who filled out the form on their behalf.

An entire paper could be written on the varieties of respondents who made the decision to choose Black as one of multiple categories, but the dilemma remains as to how to consider them for the purposes of gauging Black political aptitudes. While it is certainly possible to assume that people of mixed race may simply identify as being of mixed race, or may prefer to affiliate themselves with the majority race in order to secure the benefits of majority status, the fact is that neither practice has necessarily been followed in the United States. 
The traditional legal and social response in the United States would be that any person who falls into one of these Mixed Black categories is Black. According to Davis (1991):

The nation's answer to the question "Who is black?" has long been that a black is any person with any known African black ancestry. This definition reflects the long experience with slavery and later with Jim Crow segregation. In the South it became known as the "one-drop rule," meaning that a single drop of "black blood" makes a person a black. It is also known as the "one black ancestor rule," some courts have called it the "traceable amount rule," and anthropologists call it the "hypo-descent rule," meaning that racially mixed persons are assigned the status of the subordinate group. (p. 5).

The 'one-drop' rule is a social construct, based on popular pseudo-scientific myths propounded in the 1800s, which is unique to Black Americans. Davis (1991) notes that, "Americans... while finding other ways to discriminate against immigrant groups, have rejected the application of the drastic one-drop rule to all groups but blacks," and he explains that this rule "is found only in the United States and not in any other nation in the world" (p. 13). Historically, some persons who appear White but have some Black ancestry have taken steps to hide their Black ancestry and thus attain the privileges of being White, a process called 'passing.' Lavender (2000b) describes passing in detail: "The person who uses passing as a response to discrimination is able, because of lack of characteristics identifying the person as a member of the discrimination group as a member of their group." He goes on to explain that "the classic example in the United States is the person who is legally or socially classified as black but who, because of light color, can move to another area where the individual is unknown and be accepted as white" (p. 316). In discussions of race, as opposed to other types of social classification 
such as religion or sexual orientation, the one-drop rule is applied to no group other than Blacks. Because of this distinction, Davis (1991) suggests that the "concept of passing applies only to blacks" (p. 14).

My intention in dealing with this question is essentially to apply this 'one-drop' rule by assuming that, in our racially divided society, any respondent who is willing to acknowledge that they have some Black heritage is more likely to identify with and be sympathetic to the political plight of Blacks. Davis notes that when the task of racial categorization in the U.S. Census shifted from the Census taker to the respondent, "this did not seem to introduce any noticeable fluctuation in the number of blacks, thus indicating that black Americans generally apply the one-drop rule to themselves" (p. 12). Davis notes, however, that Hispanics and American Indians with some Black ancestry "generally reject the one-drop rule if they can," (p. 12), indicating that members of these groups who have Black ancestry but do not identify with Blacks would likely avoid admitting this, and probably would not indicate their Black ancestry on the Census.

The one-drop rule, therefore, is generally accepted by Blacks, some of whom "support it to keep from losing members of their group to the dominant white group" (Lavender, 2000a, p. 742). Persons who wish to reject or deny Black ancestry (and are physically able to get away with it) will do so, and will subsequently not formally acknowledge this heritage. These factors point towards the much greater likelihood of those who define themselves in the Census as some form of Mixed Blacks identifying as Black, regardless of other elements of their ancestry. As noted above, fewer than half of all Mixed Black respondents identified themselves as 'Black and White,' and more than one third did not indicate that they had any White ancestry at all. Mixed respondents 
with no acknowledged White heritage would have no reason to identify with Whites at all, and it is certainly more likely that they would be politically aligned with Blacks.

It is also interesting to note that, as the Black proportion of a state population increases, the proportion of Black respondents who indicate that they are of mixed heritage goes down. The mean percentage of Mixed Black as a proportion of the total Black population for the top 20 states by Black proportion, which are the only states with Black proportions higher than $10 \%$, is 3.3144 , with a standard deviation of 1.7527 ; while the mean percentage of Mixed Black as a proportion of the total Black population for the 20 states with less than $5 \%$ Black proportion is 23.0118 , with a standard deviation of 8.5949. A linear regression analysis of these variables indicates that an increase in $1 \%$ of the Black proportion of the population of a state corresponds with a decrease of more than 6.18 in the proportion of Black Any Census respondents who claim to have a Mixed Black heritage, with an impressive R-squared of 0.466. This might be indicative of the segregated nature of the Southern states which happen to have the highest Black proportions, where miscegenation has historically been frowned upon and the progeny of such activity is frequently classified as being only Black. This premise seems to be slightly bolstered by the fact that if we examine only those thirteen states which have proportions higher than $10 \%$ Black and which are categorized as Southern by Census region, the mean percentage of Mixed Black as a proportion of the total Black population of these states drops to 2.4792 , with a standard deviation of 1.4010 .

In such cases, Blacks may be inclined to formally deny their White lineage, although they may be aware of it and willing to discuss it in an informal context. It is also important to note that in those states where miscegenation has been strictly 
discouraged in the past (and is still frowned upon in some social circles), individuals who are apparently Black or apparently White may have a mixed race background of which they are completely unaware, or which they may suspect but be unable to prove. As Davis (1991) notes, "most parents of black American children in recent decades have themselves been racially mixed, but often the fractions get complicated because earlier details of the mixing were obscured generations ago" (p.6). In either case, the superior social status of Whites also suggests the likelihood that a much lower proportion of people who generally consider themselves to be White would be willing to acknowledge Black ancestry, compared to the proportion of Blacks who would be willing to acknowledge that they have some White ancestry.

Another factor that is likely to influence the proportion of Mixed Blacks among the entire Black population is the increased level of interaction with members of other groups by a minority as that minority becomes a smaller proportion of the whole population. In a state with a large Black population, it is easier for Blacks to interact almost exclusively with other Blacks. On the other hand, in a state where only a very small percentage of people are Black, members of that minority group will have a much higher likelihood of interactions with members of other groups, including relationships and marriages. In such a state, Blacks will be less likely to be seen as a threat to the social, economic, and political order, and may be more accepted at all levels of society. Based on the preceding analysis, I feel that it is appropriate to use the 'Black Any' numbers in discussions of state populations and changes therein. Wherever it is germane, however, I will provide figures indicating both the 'Black Only' and 'Black Any' outcomes of a given scenario. 
Having settled, for the time being, the question of how to calculate the Black population, this analysis now turns to the actual calculation of the number of Black people who would need to move into a state in order to affect a majority. It is important to recognize that a simple majority of the population does not, by itself guarantee political control. Grofman et al. (1992) note, for example, that "minority populations most often have lower levels of eligibility, registration, and turnout than do majority populations... it has been known for some time that creating districts in which a minority group has a bare majority of the population is unlikely to provide a realistic chance of electing a candidate preferred by the minority community" (p. 118). They conclude that "if a district is created in which it is estimated that half of the actual voters will be minority members, it is not certain that this will effectively equalize the opportunity of the majority and minority communities to elect candidates of their choice... even an 'effective majority' may not be adequate to provide a realistic opportunity to elect candidates of choice, as such a purely numerical threshold does not take into account financial and other disadvantages faced by minority (or minority-backed) candidates and does not take into account the advantages of incumbency, which are often held by nonminorities" (p. 121).

In determining the number that would be needed to assure political determination for the minority group, Grofman et al. (1992) apply a formula that accounts for age, citizenship, and consistent levels of registration and turnout. They determine that "effective voting equality for blacks may at times require little more than 50 percent of the total population, though the usual requirement is for between 55 and 60 percent, and the figure is sometimes as high as 65 percent” (p. 119). Canon (1999) ties this figure to 
regional race relations, stating that in some areas, "where racial bloc voting is especially severe, a 60-65 percent black population may be required to ensure the election of a black representative... given the differential turnout rates of blacks and whites" (pp 9-10).

Lusane (1994) suggests that lower rates of Black political participation are partially the result of the sentiment shared by members of these communities that they do not have a real impact on their plight. "Partially out of sheer frustration and partially out of exercising a conscious political decision," Lusane writes, "voter registration and turnout in low-income Black communities are often severely depressed" (p. 64). Frymer (1999) adds to this his assertion that Blacks do not even have influence within the Democratic Party congruent with their level of support for Democratic candidates, stating that those "who are marginalized from the political system do not vote; those who do not vote are neglected even further" (p. 131).

Although a variety of factors might play into the ability of Blacks to command an actual voting majority, we will assume for the purposes of this thesis that the traditional majority of 'fifty percent plus one' will be sufficient. It can be inferred from the nature of the settlement strategy itself that those Blacks who are willing to relocate as part of this strategy will also be willing to take the necessary steps to become registered and participate in elections in the state in which they settle. Furthermore, it is unnecessary to consider the age of the populations in question, as it is reasonable to expect that this strategy would take at least several years to enact. Therefore, it is likely that some of those who are not old enough to vote at the beginning of the migration process may well have reached the necessary age by the time a majority is achieved. Although further investigations might unearth contradictory information, we will assume for the purposes 
of this thesis that a bare majority will be sufficient for Blacks to assume political control over a state, recognizing that it may later be discovered that a greater majority is required.

The actual number of Black voters that would have to be added to establish a majority of all voters shall hereafter be referred to as the 'population differential.' This figure can be calculated quite simply, by subtracting the total Black population of the state from the total non-Black population of the state. Table IV, which is distributed over the following two pages, contains these calculations for each of the 50 states, plus the District of Columbia, ranked from lowest to highest. Of course, the District of Columbia is not a state - if it were, the strategy examined herein would be unnecessary! 


\section{Table IV.}

Calculation of Differentials

(the number of Black who would need to move into a state in order to establish a Black majority within that state)

ranked from lowest to highest.

\begin{tabular}{|l|r|r|r|r|}
\hline \multicolumn{1}{|c|}{ STATE } & \multicolumn{1}{c|}{$\begin{array}{c}\text { Total } \\
\text { Population }\end{array}$} & $\begin{array}{c}\text { Non-Black } \\
\text { Population }\end{array}$ & $\begin{array}{r}\text { Black Any } \\
\text { Population }\end{array}$ & $\begin{array}{c}\text { Population } \\
\text { Differential }\end{array}$ \\
\hline District of Col. & 572,059 & 221,604 & 350,455 & $-128,851$ \\
Delaware & 783,600 & 626,448 & 157,152 & 469,296 \\
Wyoming & 493,782 & 488,919 & 4,863 & 484,056 \\
Alaska & 626,932 & 599,785 & 27,147 & 572,638 \\
Vermont & 608,827 & 604,335 & 4,492 & 599,843 \\
North Dakota & 642,200 & 636,828 & 5,372 & 631,456 \\
South Dakota & 754,844 & 748,157 & 6,687 & 741,470 \\
Mississippi & $2,844,658$ & $1,802,950$ & $1,041,708$ & 761,242 \\
Montana & 902,195 & 897,754 & 4,441 & 893,313 \\
Rhode Island & $1,048,319$ & 990,268 & 58,051 & 932,217 \\
Hawaii & $1,211,537$ & $1,178,194$ & 33,343 & $1,144,851$ \\
New Hampshire & $1,235,786$ & $1,223,568$ & 12,218 & $1,211,350$ \\
Maine & $1,274,923$ & $1,265,370$ & 9,553 & $1,255,817$ \\
Idaho & $1,293,953$ & $1,285,826$ & 8,127 & $1,277,699$ \\
Louisiana & $4,468,976$ & $3,000,659$ & $1,468,317$ & $1,532,342$ \\
Nebraska & $1,711,263$ & $1,635,430$ & 75,833 & $1,559,597$ \\
South Carolina & $4,012,012$ & $2,811,111$ & $1,200,901$ & $1,610,210$ \\
West Virginia & $1,808,344$ & $1,745,527$ & 62,817 & $1,682,710$ \\
Nevada & $1,998,257$ & $1,847,749$ & 150,508 & $1,697,241$ \\
New Mexico & $1,819,046$ & $1,776,634$ & 42,412 & $1,734,222$ \\
Arkansas & $2,673,400$ & $2,246,248$ & 427,152 & $1,819,096$ \\
Alabama & $4,447,100$ & $3,278,102$ & $1,168,998$ & $2,109,104$ \\
Utah & $2,233,169$ & $2,208,787$ & 24,382 & $2,184,405$ \\
Maryland & $5,296,486$ & $3,771,450$ & $1,525,036$ & $2,246,414$ \\
Kansas & $2,688,418$ & $2,517,808$ & 170,610 & $2,347,198$ \\
Connecticut & $3,405,565$ & $3,066,487$ & 339,078 & $2,727,409$ \\
\hline
\end{tabular}

Source: U.S. Census 
Table IV. (cont.)

Calculation of Differentials

(the number of Black who would need to move into a state in order to establish a Black majority within that state)

ranked from lowest to highest.

\begin{tabular}{|l|r|r|r|r|}
\hline \multicolumn{1}{|c|}{ STATE } & \multicolumn{1}{c|}{$\begin{array}{c}\text { Total } \\
\text { Population }\end{array}$} & $\begin{array}{c}\text { Non-Black } \\
\text { Population }\end{array}$ & $\begin{array}{r}\text { Black Any } \\
\text { Population }\end{array}$ & $\begin{array}{r}\text { Population } \\
\text { Differential }\end{array}$ \\
\hline Iowa & $2,926,324$ & $2,853,812$ & 72,512 & $2,781,300$ \\
Oklahoma & $3,450,654$ & $3,165,888$ & 284,766 & $2,881,122$ \\
Oregon & $3,421,399$ & $3,348,752$ & 72,647 & $3,276,105$ \\
Georgia & $8,186,453$ & $5,793,028$ & $2,393,425$ & $3,399,603$ \\
Kentucky & $4,041,769$ & $3,729,891$ & 311,878 & $3,418,013$ \\
Tennessee & $5,689,283$ & $4,735,934$ & 953,349 & $3,782,585$ \\
Colorado & $4,301,261$ & $4,110,544$ & 190,717 & $3,919,827$ \\
Virginia & $7,078,515$ & $5,637,308$ & $1,441,207$ & $4,196,101$ \\
Missouri & $5,595,211$ & $4,939,834$ & 655,377 & $4,284,457$ \\
North Carolina & $8,049,313$ & $6,273,030$ & $1,776,283$ & $4,496,747$ \\
Minnesota & $4,919,479$ & $4,716,507$ & 202,972 & $4,513,535$ \\
Wisconsin & $5,363,675$ & $5,037,169$ & 326,506 & $4,710,663$ \\
Arizona & $5,130,632$ & $4,945,033$ & 185,599 & $4,759,434$ \\
Indiana & $6,080,485$ & $5,542,470$ & 538,015 & $5,004,455$ \\
Washington & $5,894,121$ & $5,655,723$ & 238,398 & $5,417,325$ \\
Massachusetts & $6,349,097$ & $5,950,618$ & 398,479 & $5,552,139$ \\
New Jersey & $8,414,350$ & $7,202,600$ & $1,211,750$ & $5,990,850$ \\
Michigan & $9,938,444$ & $8,463,831$ & $1,474,613$ & $6,989,218$ \\
Illinois & $12,419,293$ & $10,481,622$ & $1,937,671$ & $8,543,951$ \\
Ohio & $11,353,140$ & $9,980,639$ & $1,372,501$ & $8,608,138$ \\
Pennsylvania & $12,281,054$ & $10,991,931$ & $1,289,123$ & $9,702,808$ \\
Florida & $15,982,378$ & $13,510,648$ & $2,471,730$ & $11,038,918$ \\
New York & $18,976,457$ & $15,742,292$ & $3,234,165$ & $12,508,127$ \\
Texas & $20,851,820$ & $18,358,763$ & $2,493,057$ & $15,865,706$ \\
California & $33,871,648$ & $31,358,607$ & $2,513,041$ & $28,845,566$ \\
\hline
\end{tabular}

Source: U.S. Census 
The importance of several figures within this table is immediately apparent. The first is the differential in the District of Columbia, which is a negative number because Blacks are already in the majority therein. The second is the differential in Delaware, which is only 469,296 , the lowest of any state. The third item worth noting is the differential in Mississippi, which is 761,242 . This is important because Mississippi has the lowest differential of any state in the South, and in the context of the total population of Mississippi, which is over $36 \%$ Black. It is also important to note the differentials in California, Texas, New York, and Florida all of which are in excess of 10,000,000 (with California's exceeding $28,000,000$ ). The settlement of these states would probably present an insurmountable challenge, despite the fact that they are also the four states with the highest Black populations. The Black population of any one of these states, however, is sufficient to establish a Black majority in the top four states with the lowest differentials; the Black population of these four states combined is sufficient to establish Black majorities in the top twelve states with the lowest differentials.

In fact, if the Black population of the United States had sufficient resources, coordination, and unity of purpose to redistribute itself from all of the states with the highest differentials (many of which are large states with very large Black populations) to all of the states with the lowest differentials, they could in this way attain majority status in no fewer than twenty-three states, yielding control of 46 Senate seats, 68 Representative seats (albeit at the cost of any seats held in the states from which they would initially be moving), and 117 electoral votes, which is roughly one fifth of the entire electoral college. 
Such a redistribution would, in any practical sense, be impossible. The resources do not exist to enable it, and even if they did, there are bound to be many Blacks who would be ideologically opposed to such a strategy, and many, many more who simply would not wish to relocate because they are happy where they are. However, the fact that such a feat is technically possible does highlight the comparative ease with which a Black majority could be established through a relatively small migration to a state with a very low differential. Another way of thinking about these numbers is to examine the percentage of Blacks who are living outside a state who would have to move into that state in order to establish a majority. Table $\mathrm{V}$, on the following page, demonstrates that in some cases, this percentage is surprisingly low.

Five states would require less than $2 \%$ of the total Black population outside of those states to relocate in order to establish a Black majority. While some of those states-particularly Wyoming, Alaska, and North Dakota-are far removed from areas where the Black population is heavily concentrated, Delaware and Vermont are not. Mississippi and Rhode Island are also reasonably close to some of the prominent centers of the Black population. 


\section{Table V.}

Percentage of Blacks* living outside a state required to move into that state in order to achieve a Black majority, ranked from lowest to highest.

\begin{tabular}{|l|l|}
\hline STATE & $\%$ \\
\hline Delaware & 1.294 \\
Wyoming & 1.329 \\
Alaska & 1.574 \\
Vermont & 1.647 \\
North Dakota & 1.734 \\
South Dakota & 2.036 \\
Mississippi & 2.152 \\
Montana & 2.453 \\
Rhode Island & 2.564 \\
Hawaii & 3.146 \\
New Hampshire & 3.327 \\
Maine & 3.449 \\
Idaho & 3.509 \\
Nebraska & 4.291 \\
Louisiana & 4.384 \\
South Carolina & 4.572 \\
West Virginia & 4.628 \\
Nevada & 4.680 \\
New Mexico & 4.767 \\
Arkansas & 5.054 \\
Alabama & 5.983 \\
Utah & 6.002 \\
Maryland & 6.438 \\
Kansas & 6.475 \\
Connecticut & 7.559 \\
\hline
\end{tabular}

\begin{tabular}{|l|r|}
\hline & \multicolumn{1}{|c|}{ STATE } \\
\hline Iowa & 7.652 \\
Oklahoma & 7.973 \\
Oregon & 9.013 \\
Kentucky & 9.466 \\
Georgia & 9.991 \\
Tennessee & 10.665 \\
Colorado & 10.820 \\
Missouri & 11.980 \\
Virginia & 11.996 \\
Minnesota & 12.463 \\
North Carolina & 12.980 \\
Wisconsin & 13.051 \\
Arizona & 13.135 \\
Indiana & 13.947 \\
Washington & 14.973 \\
Massachusetts & 15.414 \\
New Jersey & 17.016 \\
Michigan & 20.001 \\
Ohio & 24.562 \\
Illinois & 24.778 \\
Pennsylvania & 27.619 \\
Florida & 32.517 \\
New York & 37.692 \\
Texas & 46.765 \\
California & 85.074 \\
\hline
\end{tabular}

* Calculated by Black Any population.

Source: U.S. Census 
The percentage of all Blacks who would need to move into the states with very low differentials appears very small indeed when viewed in this context. But how large is the differential relative to the number of Blacks who would be willing and able to move to another state in order to create a majority-Black state? The question of whether or not Blacks would be willing to move on the scale necessary to affect a majority in a given state can be answered in part by looking at the actual mobility of Blacks as reported by the United States Census, and by analyzing data from the General Social Survey (GSS). Census data reveals that Blacks move from state to state in very high numbers, although not in consistently higher proportions than Whites. Table VI, on the following page, indicates the number of people moving from state to state in three randomly selected years during the 1990s, as reported by the U.S. Census. The table contains data for those who moved from one state to another within one of the nine Census divisions, as well as the total number of people who moved from any state to any other state. 
Interstate Mobility by Race in randomly selected years.

\begin{tabular}{|c|c|c|c|c|}
\hline & Total & $\begin{array}{l}\text { Different State, } \\
\text { same division }\end{array}$ & $\begin{array}{l}\text { Total state to } \\
\text { state movers }\end{array}$ & $\begin{array}{l}\text { As } \% \text { of } \\
\text { total pop. }\end{array}$ \\
\hline $\begin{array}{l}1999-2000^{\mathrm{a}} \\
\text { All Races } \\
\text { White } \\
\text { Black } \\
\% \text { Black }\end{array}$ & $\begin{array}{l}270,219,000 \\
221,703,000 \\
34,948,000 \\
12.93 \%\end{array}$ & $\begin{array}{l}4,062,000 \\
2,992,000 \\
807,000 \\
19.87 \%\end{array}$ & $\begin{array}{l}8,428,000 \\
6,701,000 \\
1,264,000 \\
15.00 \%\end{array}$ & $\begin{array}{l}3.119 \% \\
3.023 \% \\
3.617 \%\end{array}$ \\
\hline $\begin{array}{l}1995-1996^{\mathrm{a}} \\
\text { All Races } \\
\text { White } \\
\text { Black } \\
\% \text { Black }\end{array}$ & $\begin{array}{l}260,406,000 \\
215,344,000 \\
33,294,000 \\
12.79 \%\end{array}$ & $\begin{array}{l}3,113,000 \\
2,692,000 \\
291,000 \\
9.35 \%\end{array}$ & $\begin{array}{l}6,471,000 \\
5,516,000 \\
651,000 \\
10.06 \% \\
\end{array}$ & $\begin{array}{l}2.485 \% \\
2.561 \% \\
1.955 \%\end{array}$ \\
\hline $\begin{array}{l}1992-1993^{\mathrm{a}} \\
\text { All Races } \\
\text { White } \\
\text { Black } \\
\% \text { Black }\end{array}$ & $\begin{array}{l}253,069,000 \\
208,754,000 \\
31,366,000 \\
12.39 \%\end{array}$ & $\begin{array}{l}3,393,000 \\
1,956,000 \\
401,000 \\
11.82 \% \\
\end{array}$ & $\begin{array}{l}7,480,000 \\
5,689,000 \\
779,000 \\
10.41 \% \\
\end{array}$ & $\begin{array}{l}2.956 \% \\
2.725 \% \\
2.484 \%\end{array}$ \\
\hline
\end{tabular}

a. from May $1^{\text {st }}$ of the first year to May $1^{\text {st }}$ of the second year

b. Census divisions are as follows:

New England - Connecticut, Maine, Massachusetts, New Hampshire, Rhode Island, Vermont

Middle Atlantic - New Jersey, New York, Pennsylvania

East North Central - Illinois, Indiana, Michigan, Ohio, Wisconsin

West North Central - Iowa, Kansas, Minnesota, Missouri, Nebraska, North and South Dakota

South Atlantic - Delaware, District of Columbia, Florida, Georgia, Maryland, North and South Carolina,

East South Central - Alabama, Kentucky, Mississippi, Tennessee

West South Central - Arkansas, Louisiana, Oklahoma, Texas

Mountain - Arizona, Colorado, Idaho, Montana, Nevada,

New Mexico, Utah, Wyoming

Pacific - Alaska, California, Hawaii, Oregon, Washington

Source: U.S. Census Bureau 
Of particular interest to this analysis is the fact that in any given year, a sufficient number of Blacks move from one state to another to establish majorities in many of the states as calculated in Table IV, if this migration was targeted and coordinated. The average number of Black state-to-state movers in the three years examined is 898,000 , or $2.685 \%$ of the total Black population of America in a given year, which is enough to establish a majority in any of the first eight states in Table IV. Even the number for the lowest year, 651,000 in 1995-96, would be sufficient to establish a majority in any of the first five states in Table IV.

Having established that Blacks do indeed move from state to state in sufficient numbers that this strategy could be enacted if typical Black migration was coordinated towards this end, we now move to the question of whether or not Blacks would be willing to move for the specific purpose of establishing a majority in a state. There is no direct date to suggest the answer to this question one way or another. However, there is at least some indirect data to be gleaned from 1996 administration of the General Social Survey, which asked respondents the following question:

If you could improve your work or living conditions, how willing or unwilling would you be to...
A. Move to another neighborhood (or village)
B. Move to another town or city within this state
C. Move to another state
D. Move outside America
E. Move outside North America

The question of greatest concern to this strategy is the degree to which Black respondents would be willing to move to another state. Table VII on the following page demonstrates that Blacks respondents indicate a significant willingness do so. 


\section{Table VII.}

Willingness of GSS respondents to move to another state in order to 'improve work or living conditions'

\begin{tabular}{|l|c|c|c|c|}
\hline \multirow{4}{*}{ Very Willing } & \multicolumn{2}{|c|}{ White } & \multicolumn{2}{c|}{ Black } \\
\cline { 2 - 5 } Willing & $\mathrm{N}$ & $\%$ & $\mathrm{~N}$ & $\%$ \\
\cline { 2 - 5 } $\begin{array}{l}\text { Neutral } \\
\text { Unwilling }\end{array}$ & 250 & 19.62 & 46 & 27.06 \\
\cline { 2 - 5 } & 158 & 14.84 & 22 & 12.94 \\
\cline { 2 - 5 } Very Unwilling & 193 & 18.12 & 14 & 8.24 \\
\cline { 2 - 5 } & 255 & 23.94 & 52 & 30.59 \\
\hline TOTAL & 1065 & 100.00 & 170 & 100.00 \\
\hline
\end{tabular}

Source: General Social Survey, 1996

As this data shows, nearly half of all Black respondents indicated that they would be willing to move to a different state for improved working or living conditions, with over $27 \%$ indicating that they would be 'very willing' to make such a move. This seems to agree with the data on actual migration from the U.S. Census. While people may be prompted to move from one location to another for many different reasons, presumably the belief that a better life is to be found at their destination would be among the more compelling motivations. Projected to the whole of the adult Black population, it would indicate that some 5,974,000 Black adults would be 'very willing' to move to another state, which would be enough to establish a majority in any state in Table IV except for the nine states with the highest differentials; and that close to $10,650,000$ - enough establish a majority in any state in Table IV except for California, Texas, New York, and Florida-would at least be 'willing' to make such a move. 
Of course, such a leap of analysis assumes several things - first and foremost that Blacks would consider moving for the purpose of creating a majority-Black state to be tantamount to moving 'improve work or living conditions.' Whether or not Blacks would expect to attain an improvement in their living or working conditions by moving to a majority-Black state, or a state intended to become majority-Black state, is another question that must be reserved for further research. Because the idea of establishing a majority-Black state has not been popularly discussed in more than a generation, it is doubtful that many Blacks have ever thought about whether they would move to a state for the purpose of creating a Black majority, or even whether they would move to a state that already had such a majority.

\section{How Can a Group Best Achieve a Voting Majority In a State?}

The first question that arises in the examination of the viability and efficacy of this strategy is: what state would make the most logical choice for settlement? A wide variety of factors must be considered in order to develop an answer to this question, some tied to practical logistical matters, and others related to the political goals of this endeavor. Logistical concerns include those of the existing population of a target state and the surrounding area. Would it be better to settle a small state, thus minimizing the necessary resources, or to settle a fairly large state, and thus obtain the benefits of perhaps eight or ten additional seats in the House of Representatives? Is the infrastructure of the state capable of absorbing a large immigration? Would Blacks 
benefit more by settling a very conservative state which produces members of the U.S. House and Senate who oppose Black issues, or a more liberal state where they would meet less resistance and could more easily form governing coalitions?

An assessment of the viability of a state for settlement must begin with an estimation of the effort that would be required to establish a simple Black majority of all eligible voters. The Black proportion of the population in a particular state could theoretically be increased by a number of means, although the most practical would be through migration. Increased intermarriage, for example, would produce more biracial children who would be identified as Black according to the 'one-drop' rule. Identification of the descendents of Blacks who have passed as White would have this effect also, although such a strategy might backfire if pursued vigorously—persons with undiscovered Black ancestry who have identified as White all their lives would not necessarily begin to identify with Blacks simply because some Black ancestry is exposed. Instead, they may choose to completely deny this heritage, or may push for a change in the definition of Blackness that moves away from the one-drop rule itself.

Many states have a small proportion of people residing therein who are not citizens of that state, but who choose instead to maintain their citizenship in another state such as their state where they were born. They may identify with that other state and possibly even vote there via absentee ballot, but might at the same time meet all of the qualifications for citizenship in the state where they are actually living. Some small impact might result from encouraging Black noncitizen residents of a state to take the necessary steps to become citizens within that state. As a long-term strategy, it could 
even be suggested that increased life expectancy and mortality rates of Blacks through improved medical care would accelerate the growth of the Black population.

Migration into a state, however, is clearly the fastest, simplest, and most practical way to achieve a Black majority. As Clayton (2000) says, the "increase in the number of blacks serving in Congress is the result of a variety of factors. The migration of black America has played a critical role in shaping the political landscape of America" (p. 22).

One strategy that could work in tandem with a migration, albeit with some obvious negative possible repercussions, would be aggressive block-busting in municipal areas that straddle state borders. The specter of large numbers of Blacks moving into previously all-White neighborhoods at or near the state border might compel those Whites who would prefer not to have Black neighbors to cross the border and move to suburbs in the neighboring state.

\section{Incorporating Existing Patterns of Migration and Population Growth}

The ongoing return migration of Blacks to the South provides an excellent jumping-off point from which to discuss the possibility of establishing a majority-Black state through migration. This well-documented phenomenon has led to steady increases in the Black populations of states which had experienced a decline in this population up until the 1960s. The factors that are compelling many Blacks to undertake this migration might be used to draw this migratory population to a specific state. It would also likely 
be easier to increase and focus an existing pattern of migration than it would be to create an entirely new pattern.

Stack (1996) examines the ongoing Southern return migration from an anthropological perspective, noting that from about 1975, "the U.S. Bureau of the Census released the first numbers suggesting that the exodus of black Americans from the southern countryside to the cities of the North and West was turning back on itself. Black Americans who had spent all or part of a lifetime in large industrial cities were abandoning urban life and moving south, sometimes back to the homeplaces of their childhood" (p. xiii). She adds that more recent Census figures confirm the Southward migration, stating that by 1990 "the South had gained more than half a million black Americans who were leaving the North-or more precisely, the South had regained from the cities of the North the half-million black citizens it had lost to northward migration during the 1960s. The Census bureau now predicts that the southward trend will continue" (p. xiv).

The effects of this Southern migration can clearly be seen in the tables on the following four pages. The Table VII shows the population in each state as recorded in the decennial Census from 1970, through 1980 and 1990, to 2000. The rate of increase from 1990 to 2000 is also shown, and the states are ranked in order of this rate of increase, from highest to lowest. Table IX shows the Black proportion of the total population in each state as recorded in the decennial Census from 1970, through 1980 and 1990, to 2000. Again, the rate of increase from 1990 to 2000 is also shown, and the states are ranked in order of this rate of increase, from highest to lowest. It is important to keep in mind that, because these numbers reflect proportional growth, they are 
tempered by their relationship to the growth of the non-Black population. This is clearly reflected in the case of California, which was the seventh highest state in terms of actual Black population growth, but was the only state to show a decrease in the Black proportion of the total population, resulting from faster growth rates by other groups.

These tables show that both the highest occurrences of Black population growth and the highest occurrences of growth of the Black proportion of the total population have tended to occur in Southern states. Georgia is near the top of both tables, while Maryland and Delaware both demonstrate phenomenal growth in the Black proportion. Florida, Texas and North Carolina, like California, experienced immense Black population growth that is not clearly reflected in the Black proportion because other groups also grew significantly during this time. This is particularly important in consideration of the fact that enacting a settlement strategy may take a considerable period of time-perhaps a decade or more-during which the rate of increase of the Black population of the target state must outpace that of the White population. 


\section{Table VIII.}

Black population by decade from 1970 to 2000 ranked by rate of increase in Black population from 1990 to 2000, from highest to lowest.

\begin{tabular}{|l|r|r|r|r|r|}
\hline \multicolumn{1}{|c|}{ STATE } & \multicolumn{1}{c|}{1970} & \multicolumn{1}{c|}{1980} & \multicolumn{1}{c|}{1990} & \multicolumn{1}{c|}{2000} & $1990-2000$ \\
\hline Florida & $1,042,000$ & $1,343,000$ & $1,759,534$ & $2,471,730$ & $+712,196$ \\
Georgia & $1,187,000$ & $1,465,000$ & $1,746,565$ & $2,393,425$ & $+646,860$ \\
Texas & $1,399,000$ & $1,710,000$ & $2,021,632$ & $2,493,057$ & $+471,425$ \\
New York & $2,169,000$ & $2,402,000$ & $2,859,055$ & $3,234,165$ & $+375,110$ \\
Maryland & 699,000 & 958,000 & $1,189,899$ & $1,525,036$ & $+335,137$ \\
North Carolina & $1,126,000$ & $1,319,000$ & $1,456,323$ & $1,776,283$ & $+319,960$ \\
California & $1,400,000$ & $1,819,000$ & $2,208,801$ & $2,513,041$ & $+304,240$ \\
Virginia & 861,000 & $1,009,000$ & $1,162,994$ & $1,441,207$ & $+278,213$ \\
Illinois & $1,426,000$ & $1,675,000$ & $1,694,273$ & $1,937,671$ & $+243,398$ \\
Ohio & 970,000 & $1,077,000$ & $1,154,826$ & $1,372,501$ & $+217,675$ \\
Pennsylvania & $1,017,000$ & $1,047,000$ & $1,089,795$ & $1,289,123$ & $+199,328$ \\
Michigan & 991,000 & $1,199,000$ & $1,291,706$ & $1,474,613$ & $+182,907$ \\
Tennessee & 621,000 & 726,000 & 778,035 & 953,349 & $+175,314$ \\
New Jersey & 770,000 & 925,000 & $1,036,825$ & $1,211,750$ & $+174,925$ \\
Louisiana & $1,087,000$ & $1,238,000$ & $1,299,281$ & $1,468,317$ & $+169,036$ \\
South Carolina & 789,000 & 949,000 & $1,039,884$ & $1,200,901$ & $+161,017$ \\
Alabama & 903,000 & 996,000 & $1,020,705$ & $1,168,998$ & $+148,293$ \\
Mississippi & 816,000 & 887,000 & 915,057 & $1,041,708$ & $+126,651$ \\
Minnesota & 35,000 & 53,000 & 94,944 & 202,972 & $+108,028$ \\
Missouri & 480,000 & 514,000 & 548,208 & 655,377 & $+107,169$ \\
Indiana & 357,000 & 415,000 & 432,092 & 538,015 & $+105,923$ \\
Massachusetts & 176,000 & 221,000 & 300,130 & 398,479 & $+98,349$ \\
Washington & 71,000 & 106,000 & 149,801 & 238,398 & $+88,597$ \\
Wisconsin & 128,000 & 183,000 & 244,539 & 326,506 & $+81,967$ \\
Arizona & 53,000 & 75,000 & 110,524 & 185,599 & $+75,075$ \\
\hline
\end{tabular}

Source: U.S. Census 
Table VIII. (cont.)

Black population by decade from 1970 to 2000 ranked by rate of increase in Black population from 1990 to 2000 , from highest to lowest.

\begin{tabular}{|l|r|r|r|r|r|}
\hline \multicolumn{1}{|c|}{ STATE } & \multicolumn{1}{c|}{1970} & 1980 & \multicolumn{1}{c|}{1990} & 2000 & $1990-2000$ \\
\hline Nevada & 28,000 & 51,000 & 78,771 & 150,508 & $+71,737$ \\
Connecticut & 181,000 & 217,000 & 274,269 & 339,078 & $+64,809$ \\
Colorado & 66,000 & 102,000 & 133,146 & 190,717 & $+57,571$ \\
Arkansas & 352,000 & 374,000 & 373,912 & 427,152 & $+53,240$ \\
Oklahoma & 172,000 & 205,000 & 233,801 & 284,766 & $+50,965$ \\
Kentucky & 231,000 & 259,000 & 262,907 & 311,878 & $+48,971$ \\
Delaware & 78,000 & 96,000 & 112,460 & 157,152 & $+44,692$ \\
Kansas & 107,000 & 126,000 & 143,076 & 170,610 & $+27,534$ \\
Oregon & 26,000 & 37,000 & 46,178 & 72,647 & $+26,469$ \\
Iowa & 33,000 & 42,000 & 48,090 & 72,512 & $+24,422$ \\
Rhode Island & 25,000 & 28,000 & 38,861 & 58,051 & $+19,190$ \\
Nebraska & 40,000 & 48,000 & 57,404 & 75,833 & $+18,429$ \\
Utah & 7,000 & 9,000 & 11,576 & 24,382 & $+12,806$ \\
New Mexico & 20,000 & 24,000 & 30,210 & 42,412 & $+12,202$ \\
West Virginia & 67,000 & 65,000 & 56,295 & 62,817 & $+6,522$ \\
Hawaii & 8,000 & 17,000 & 27,195 & 33,343 & $+6,148$ \\
New Hampshire & 3,000 & 4,000 & 7,198 & 12,218 & $+5,020$ \\
Idaho & 2,000 & 3,000 & 3,370 & 8,127 & $+4,757$ \\
Alaska & 9,000 & 14,000 & 22,451 & 27,147 & $+4,696$ \\
Maine & 3,000 & 3,000 & 5,138 & 9,553 & $+4,415$ \\
South Dakota & 2,000 & 2,000 & 3,258 & 6,687 & $+3,429$ \\
Vermont & 1,000 & 1,000 & 1,951 & 4,492 & $+2,541$ \\
Montana & 2,000 & 2,000 & 2,381 & 4,441 & $+2,060$ \\
North Dakota & 2,000 & 3,000 & 3,524 & 5,372 & $+1,848$ \\
Wyoming & 3,000 & 3,000 & 3,606 & 4,863 & $+1,257$ \\
\hline
\end{tabular}

Source: U.S. Census 


\section{Table VIII.}

Black proportion by decade from 1970 to 2000 ranked by rate of increase in Black proportion from 1990 to 2000, from highest to lowest.

\begin{tabular}{|l|r|r|r|r|r|}
\hline \multicolumn{1}{|c|}{ STATE } & \multicolumn{1}{c|}{1970} & \multicolumn{1}{c|}{1980} & \multicolumn{1}{c|}{1990} & \multicolumn{1}{c|}{2000} & $1990-2000$ \\
\hline Maryland & 17.823 & 22.718 & 24.886 & 28.793 & +3.908 \\
Delaware & 14.234 & 16.162 & 16.882 & 20.055 & +3.174 \\
Georgia & 25.861 & 26.817 & 26.961 & 29.236 & +2.276 \\
Louisiana & 29.854 & 29.434 & 30.789 & 32.856 & +2.067 \\
Minnesota & 0.920 & 1.300 & 2.170 & 4.126 & +1.956 \\
Florida & 15.348 & 13.780 & 13.600 & 15.465 & +1.866 \\
Rhode Island & 2.640 & 2.957 & 3.873 & 5.538 & +1.665 \\
Connecticut & 5.970 & 6.982 & 8.344 & 9.957 & +1.613 \\
Virginia & 18.524 & 18.870 & 18.796 & 20.360 & +1.564 \\
Ohio & 9.106 & 9.974 & 10.646 & 12.089 & +1.443 \\
Pennsylvania & 8.623 & 8.825 & 9.172 & 10.497 & +1.325 \\
Massachusetts & 3.094 & 3.852 & 4.989 & 6.276 & +1.288 \\
New York & 11.893 & 13.680 & 15.892 & 17.043 & +1.151 \\
Wisconsin & 2.897 & 3.889 & 4.999 & 6.087 & +1.088 \\
Mississippi & 36.806 & 35.184 & 35.561 & 36.620 & +1.059 \\
Indiana & 6.873 & 7.559 & 7.794 & 8.848 & +1.055 \\
Alabama & 26.220 & 25.578 & 25.261 & 26.287 & +1.025 \\
Missouri & 10.263 & 10.454 & 10.713 & 11.713 & +1.000 \\
New Jersey & 10.742 & 12.559 & 13.413 & 14.401 & +.988 \\
Nevada & 5.726 & 6.375 & 6.554 & 7.532 & +.978 \\
Washington & 2.083 & 2.565 & 3.078 & 4.045 & +.967 \\
Michigan & 11.166 & 12.945 & 13.896 & 14.837 & +.941 \\
Oklahoma & 6.721 & 6.777 & 7.433 & 8.253 & +.820 \\
Tennessee & 15.826 & 15.814 & 15.953 & 16.757 & +.804 \\
Nebraska & 2.697 & 3.057 & 3.637 & 4.431 & +.795 \\
\hline
\end{tabular}

Source: U.S. Census 


\section{Table VIII. (cont.)}

Black proportion by decade from 1970 to 2000 , ranked by rate of increase in Black proportion from 1990 to 2000, from highest to lowest.

\begin{tabular}{|l|r|r|r|r|r|}
\hline STATE & 1970 & 1980 & 1990 & 2000 & $1990-2000$ \\
\hline Illinois & 12.831 & 14.658 & 14.822 & 15.602 & +.780 \\
Iowa & 1.169 & 1.441 & 1.732 & 2.478 & +.746 \\
Maine & .302 & .267 & .107 & .749 & +.642 \\
Arizona & 2.993 & 2.759 & 3.015 & 3.617 & +.602 \\
Kentucky & 7.176 & 7.075 & 7.134 & 7.716 & +.582 \\
Kansas & 4.762 & 5.330 & 5.775 & 6.346 & +.571 \\
Oregon & 1.243 & 1.405 & 1.625 & 2.123 & +.499 \\
Utah & .661 & .616 & .672 & 1.092 & +.420 \\
South Dakota & .300 & .289 & .468 & .886 & +.418 \\
Colorado & 2.990 & 3.529 & 4.042 & 4.434 & +.392 \\
Vermont & .225 & .196 & .347 & .738 & +.391 \\
New Hampshire & .407 & .434 & .649 & .989 & +.340 \\
New Mexico & 1.969 & 1.842 & 1.994 & 2.332 & +.338 \\
West Virginia & 3.842 & 3.333 & 3.139 & 3.474 & +.335 \\
Hawaii & 1.040 & 1.762 & 2.454 & 2.752 & +.298 \\
Idaho & .281 & .318 & .335 & .628 & +.293 \\
North Dakota & .324 & .459 & .552 & .836 & +.285 \\
Alaska & 3.000 & 3.483 & 4.082 & 4.330 & +.248 \\
Montana & .288 & .254 & .298 & .492 & +.194 \\
Wyoming & .904 & .638 & .795 & .985 & +.190 \\
South Carolina & 30.452 & 30.397 & 29.824 & 29.933 & +.108 \\
North Carolina & 22.157 & 22.424 & 21.970 & 22.068 & +.097 \\
Arkansas & 18.305 & 16.360 & 15.906 & 15.978 & +.072 \\
Texas & 12.494 & 12.018 & 11.901 & 11.956 & +.055 \\
California & 7.016 & 7.685 & 7.422 & 7.419 & -.003 \\
\hline
\end{tabular}

Source: U.S. Census 
If the trends noted above in the proportional growth of the Black population experienced from 1990 to 2000 were to continue indefinitely into the future, and if we were to assume that the 'one drop' rule would continue to apply, then every state except California could be projected to eventually have a Black majority. Maryland would be the first to cross this threshold - in April of 2055; Louisiana, Georgia, and Delaware would follow over the next thirty to forty years, followed by Mississippi in the beginning of 2126. Restricting our analysis to those who identify as Black Only reduces the number of states projected to eventually have a Black majority to 38 , and extends the amount of time anticipated to reach this threshold. Ironically, among the states that would never reach a Black majority using Black Only numbers are those which currently contain some of the highest Black Only populations-New York and Texas-along with the Southern states of Arkansas, and North and South Carolina.

These projections differ from Census projections, which are derived from much more sophisticated formulas that consider factors such as expected changes in childbirth mortality rates and life expectancy. Census projections, which predict several possible outcomes for periods ranging up to the next hundred years, do not anticipate the natural development of a majority-Black state, although they do predict a continuous increase in the Black proportion of almost all states. However, Census projections can not and do not predict changes in migration patterns. It is, admittedly, unlikely in the extreme that the same patterns of proportional population growth will continue for even a few years into the future, much less decades. Nevertheless, the eventual development of a majorityBlack state without an intentional movement behind it is also a distinct possibility. 
Table X.

First ten states to reach a majority of persons claiming any Black heritage at 1990-2000 rate of growth.

\begin{tabular}{|c|c|}
\hline State & Yrs. \\
\hline Maryland & 54.27 \\
\hline Louisiana & 82.95 \\
\hline Georgia & 91.24 \\
\hline Delaware & 94.36 \\
\hline Mississippi & 126.35 \\
\hline Florida & 185.12 \\
\hline Virginia & 189.51 \\
\hline Alabama & 231.25 \\
\hline Minnesota & 234.56 \\
\hline Connecticut & 248.28 \\
\hline
\end{tabular}

Table XI.

First ten states to reach a majority of persons claiming only Black heritage at 1990-2000 rate of growth.

\begin{tabular}{|c|c|}
\hline State & Yrs. \\
\hline Maryland & 73.48 \\
\hline Louisiana & 102.97 \\
\hline Georgia & 122.43 \\
\hline Delaware & 131.18 \\
\hline Mississippi & 174.81 \\
\hline Alabama & 328.15 \\
\hline Florida & 349.26 \\
\hline Minnesota & 352.15 \\
\hline Virginia & 359.39 \\
\hline Ohio & 472.45 \\
\hline
\end{tabular}


Table $\mathrm{X}$ indicates the top ten states which would be fastest to reach a majority of persons claiming any Black heritage if current population trends were to continue, along with the number of years this would take starting from the release of the 2000 Census; these are also the only states for which this threshold would be surpassed within 250 years. Table XI indicates the top ten fastest states to reach a Black majority if current population trends were to continue, along with the number of years this would take starting from the release of the 2000 Census; these are also the only states for which this threshold would be surpassed within half a millennium. In each case, the top five states are the same, and are in the same order: Maryland, Louisiana, Georgia, Delaware, and Mississippi. All five are Southern states (although Maryland and Delaware are only marginally so), which reflects both the existing high Black populations resulting from the heritage of slavery, and the results of the current North-to-South migration pattern.

It should be noted that non-Hispanic Whites are, in fact, already in the minority in three states-California, Hawaii, and New Mexico-although they remain the single largest group in all of those states except Hawaii. According to Meacham (2000), "Florida and Texas will reach the same tipping point before the decade [2001-2010] is out." Feagin and Sikes (1994) contend, however, that "the changing demographics, the growing number of Americans with non-European roots, do not necessarily entail a speedy shift of power to the underdog" (p. 334). This assessment has been borne out in the past, particularly in the U.S. South, which has always been an important region to Blacks, and to the fortunes of the nation as a whole.

Black and Black (1992) report that the present-day South "is the largest, the most cohesive, and, arguably, the most important region in the United States in terms of 
establishing the partisan direction of presidential politics" (p. 344). Their analysis demonstrates how the South already has enormous electoral power, and this power will only increase if we accept the accuracy of Census projections which indicate that over the next quarter-century, "70 percent of population growth will take place in the South and West, a continuation of a trend evident since the 1970s" (Morganthau, 1997).

Swain (1995), discussing multiple regression analysis of White members of Congress rated on votes dealing with Black issues, states that "southerners from both parties are less supportive of the whole range of issues... than are their colleagues from other parts of the nation" (p. 16). Hence, the settlement of a Southern state would not only fall into the existing pattern of migration, but would also likely give Blacks the opportunity to overturn the political orientation of that state in a way that would be favorable to Black interests. The calculation of the political direction of the target state must be part of the equation in making this determination.

The North to South migration pattern, along with the date regarding the recent growth of Black proportions of the population, also suggests that states located along the path from North to South could easily draw large increases in the Black proportions of their populations. This is apparent in Maryland, Delaware, and Virginia, although the latter has a very high differential that makes settlement an unreasonable option. 


\section{An Examination of Specific States}

It is tempting to point to many Western and Midwestern states with very low populations resulting in very low differentials, such as Wyoming, North and South Dakota, Montana, and even Alaska and Hawaii. However, several considerations must be taken into account which might suggest that such states would be unsuitable for settlement. First, these states currently have very low Black populations, and this is not by accident. They are far removed from the traditional corridors of Black migration, and a movement to settle one of these states would require participants to move much farther from their points of origin, which would in turn encumber greater expense. Furthermore, the lack of a sizable Black population would likely indicate a lack of the social resources-such as majority-Black churches, schools, social organizations, and business areaswhich would help Black immigrants adjust comfortably to living in a new state.

It is important to keep in mind that in a hypothetical state with an existing $25 \%$ Black population, Black immigration sufficient to establish a bare majority would only need to increase the overall population of the state by $50 \%$. A state with less than $2 \%$ Black population, on the other hand, would see its overall population nearly doubled by the necessary Black immigration. The small overall populations of these states, some of which cover a great deal of area, points to the lack of both physical infrastructure (roads, houses, electrical power, etc.) and available jobs necessary to accommodate the massive proportional population growth that would accompany settlement. The following table demonstrates the percentage increase which each state would have to bear in order to accommodate the settlement of a Black majority. 


\section{Table XII.}

Percentage increase in state population that would occur in the process of achieving a Black majority* (assuming that

no Whites left the state), ranked from lowest to highest.

\begin{tabular}{|l|c|}
\hline STATE & $\%$ \\
\hline Mississippi & $26.760 \%$ \\
Louisiana & $34.288 \%$ \\
South Carolina & $40.135 \%$ \\
Georgia & $41.527 \%$ \\
Maryland & $42.413 \%$ \\
Alabama & $47.427 \%$ \\
North Carolina & $55.865 \%$ \\
Virginia & $59.279 \%$ \\
Delaware & $59.890 \%$ \\
New York & $65.914 \%$ \\
Tennessee & $66.486 \%$ \\
Arkansas & $68.044 \%$ \\
Illinois & $68.796 \%$ \\
Florida & $69.069 \%$ \\
Michigan & $70.325 \%$ \\
New Jersey & $71.198 \%$ \\
Ohio & $75.822 \%$ \\
Texas & $76.088 \%$ \\
Missouri & $76.574 \%$ \\
Pennsylvania & $79.006 \%$ \\
Connecticut & $80.087 \%$ \\
Indiana & $82.304 \%$ \\
Oklahoma & $83.495 \%$ \\
Kentucky & $84.567 \%$ \\
Nevada & $84.936 \%$ \\
\hline
\end{tabular}

\begin{tabular}{|l|c|}
\hline \multicolumn{1}{|c|}{ STATE } & $\%$ \\
\hline California & $85.161 \%$ \\
Kansas & $87.308 \%$ \\
Massachusetts & $87.448 \%$ \\
Wisconsin & $87.825 \%$ \\
Rhode Island & $88.925 \%$ \\
Colorado & $91.132 \%$ \\
Nebraska & $91.137 \%$ \\
Alaska & $91.340 \%$ \\
Minnesota & $91.748 \%$ \\
Washington & $91.911 \%$ \\
Arizona & $92.765 \%$ \\
West Virginia & $93.053 \%$ \\
Hawaii & $94.496 \%$ \\
Iowa & $95.044 \%$ \\
New Mexico & $95.337 \%$ \\
Oregon & $95.753 \%$ \\
Utah & $97.816 \%$ \\
New Hampshire & $98.023 \%$ \\
Wyoming & $98.030 \%$ \\
South Dakota & $98.228 \%$ \\
North Dakota & $98.327 \%$ \\
Maine & $98.501 \%$ \\
Vermont & $98.524 \%$ \\
Idaho & $98.744 \%$ \\
Montana & $99.016 \%$ \\
\hline
\end{tabular}

*This calculation assumes that a Black majority could be achieved in a sufficiently short period of time to avoid the additional effects of ongoing natural population growth.

Source: U.S. Census 
States with very large existing populations may be better suited to absorb a large immigration and control of such states would provide immense political power. However, large states generally have such high differentials that settlement is simply impossible, even where large Black populations are already present in these states. The largest states, California, Texas, New York, and Florida, obviously suffer from this drawback, and Ohio, Illinois, Michigan, New Jersey, and Massachusetts would not fare much better.

Three models highlight the approaches that the Black community might take in choosing a state for settlement. The first, Delaware, has the lowest differential, and would thus be the easiest to settle. The second, Mississippi, is of great symbolic significance and would represent a complete political reversal in favor of Black interests. The third, Georgia, would be very difficult to accomplish, but would yield immense political power through the control of a large number of congressional seats and electoral votes. The particular strengths and weaknesses of each state are discussed in the following sections.

\section{Delaware}

With a significant Black proportion of its already low overall population, Delaware has the lowest differential of any state in the Union. It has an overall population of 783,600 and a Black population of over 150,000 , which means that the addition of fewer than 470,000 Blacks would suffice to tip the balance of population. Therefore, fewer than thirteen out of every thousand Blacks currently living outside of 
Delaware would have to move there to establish a majority of all residents. Delaware is well situated to accommodate a migration, as it falls directly between heavily Black areas of both the Northern and Southern states. It is in particularly close proximity to Philadelphia, which has over 672,000 Black residents, and Baltimore, which has over 424,000 Black residents; and it is only a few hours of driving out of New York City, which has over 2,274,000 Black residents.

Delaware is also fortuitously close to the center of American government in Washington D.C., and has business-friendly laws which have drawn many corporations to locate their headquarters there. Barone et al. (2001) note that "Delaware has... thrived in finance. In the late $19^{\text {th }}$ Century, it pioneered liberal laws of incorporation, giving more flexibility and power to managers and owners. A large share of the nation's big companies are incorporated in Delaware" (p. 345). Therefore, in addition to the previously discussed political benefits of state control, majority control of Delaware would give the Black leadership of the state access to some of the farthest-reaching boardrooms in America.

Delaware has only one member of the House of Representatives, and thus holds only three electoral votes. It is, as Barone et al (2001) note, already a fairly liberal state. They remark that "in the 1990s Delaware, like so many of America's largest metro areas, trended towards the Democrats, and now Democrats hold both the governorship and both Senate seats" (pp. 345-7). Senior Senator Joe Biden, consistently ranks among the most liberal in various organization surveys. From 1997 to 2000, Biden voted in support of the positions advocated by the Civil Rights Action Center, which is particularly concerned with issues of racial justice, 31 out of 36 times. It is possible, but unlikely, that the influx 
of population necessary to establish a Black majority in Delaware would sufficiently increase the population to merit a second Representative.

Only two other states offer differentials close to that of Delaware without being geographically remote. These are Vermont, with a differential of just under 600,000; and Rhode Island, with a differential of over 932,000. Neither is as well situated as Delaware, nor does either have a significant Black population. Vermont, in fact, currently has the lowest Black proportion in the country except for Idaho and Montana. Other states with reasonably low differentials that share the geographic advantages enjoyed by Delaware include West Virginia, Virginia, and Maryland. West Virginia has a differential of 1,682,710. Maryland has a much higher differential of $2,246,414$, but has the unique advantage of being the state with the fastest-growing Black proportion. Maryland also has enough congressional seats and electoral votes to make its settlement a source of considerable political power beyond the capture of senate seats and a governor's mansion. Virginia has an overwhelming differential of well over four million.

\section{Mississippi}

Mississippi has the highest Black proportion of any state in the country, with over 36 percent of the population identifying as such. With a long history of particularly brutal slavery and segregation, Mississippi would probably present the greatest symbolic victory. The settlement of Mississippi would also overturn the particularly conservative nature of the state. Currently, both Senators from Mississippi are particularly conservative Republicans, and Barone et al. (2001) state: "Politically, Mississippi is a 
conservative state, carried by Republicans in the last six presidential elections" (p.855). For exactly these reasons, however, Mississippi would also be the state where Whites would most vigorously oppose the development of a Black majority. Mississippi has four members of the House of Representatives, and a settlement sufficient to establish a Black voting majority would increase the state population sufficiently to earn a fifth, and possibly a sixth. This gain might be offset by the emigration of Whites unwilling to live under a Black government. The differential is 761,242 , but this does not take into account the disenfranchisement of over 145,000 Blacks for felony convictions, including 125,000 who have served their sentences.

Louisiana, South Carolina, and Alabama are similarly situated in terms of their size and political history, with Alabama being the most conservative of the three. All of their differentials are much higher than Mississippi's, coming in around 1.5 million, 1.6 million, and 2.1 million, respectively.

\section{Georgia}

With a voting differential of close to 3.64 million people, this state would seem to be an unlikely candidate for settlement. However, there are some factors which point towards control of Georgia as the best reasonable outcome for Blacks. Barone et al. (2001) note that Georgia has come to international prominence as "Atlanta, long a regional capital, has become a world city" (p. 426). The fifteen electoral votes held by this state give it critical power in presidential elections, and a respectable delegation of thirteen members in the House of Representatives. The congressional delegation, and 
consequently the electoral vote count, would probably increase by five or six with the necessarily large migration into the state. A Black majority in the state legislature could craft three or four overwhelmingly White districts in which to pack the bulk of White areas, creating serviceable Black majorities in as many as fifteen districts. Such an effort would essentially posit a reversal of the current situation, where there are only two Black representatives despite the fact that close to $29 \%$ of the population is Black.

A more important factor might be the status of the existing Black population of Georgia, which includes a sizable middle class centered in Atlanta.

The increase of Georgia's Black population in the 1990s was over 646,000 , second in the nation to that of Florida. This was more than 5 times the numerical increase experienced by Mississippi, and almost 15 times as much as Delaware's. Roughly ten percent of all Blacks currently living outside of Georgia would have to move there to establish a majority, but more than half of the Black population of the United States is already within two-hundred miles of Georgia's borders, including all of Alabama and Mississippi, North and South Carolina, Eastern parts of Louisiana and Arkansas, and the Northern half of Florida.

Tennessee, North Carolina, and Virginia are all large enough to provide a similar political boon if they were successfully settled, but all three have higher differentials than Georgia (with North Carolina's approaching 4.5 million), and none have as much congressional or electoral clout. Maryland has already been discussed in the context of its political value, as well as its reasonably moderate differential and fast natural growth of the Black proportion. 


\section{CHAPTER IV.}

\section{Potential Repercussions}

The development of majority-Black state, and the accompanying transition from a White governing regime to a Black governing regime, would have profoundly impact residents of that state. Similar transitions in both urban and rural counties and municipalities have resulted in political strife, as the incoming majority group struggles to assert control while the outgoing majority group seeks to maintain the power to which it is accustomed. These transitions follow familiar patterns based largely on the social preferences and ideological tendencies of the local White population. In every case to date, however, the assumption of Black majority control in an area has occurred under the auspices of a state that remains majority-White in its overall population. Succession to a Black governed state provides much previously uncharted territory, as a state is possessed of vastly more power over which groups with differing goals might contend.

The effects of success in such a venture would resonate throughout the country, because Blacks would directly control the election of two senators and the allocation of at least a small number of electoral votes. It is possible, but unlikely for various reasons, that such success could result in changes to the nature of the political orientation generally expressed by Blacks. What is more likely is that Blacks, having solidly asserted majority control over the state in question, would then have to contend with the same internal rifts over personality differences and policy distinctions that now defines much of White state politics. At the same time, the unique character of a majority-Black state would subject its government to the additional pressure of exceptional scrutiny. 


\section{Relations Between a Black Majority and a White Minority}

The likely consequences of success in an effort to establish a Black majority state can be forecast to a degree by examining the results of Black succession at the county and municipal levels. Historically, in municipalities where Blacks become a significant proportion of the population, significant numbers of Whites tend to move, either to suburbs on the outskirts of the municipality, or to highly segregated and sheltered areas within the municipality. Whites are not so likely, however, to pick up stakes and move to another state or region entirely, as many will still have ties to the city, either through their employment, or through property or business investments in the area. Even when it becomes clear that Blacks will succeed to majority status, Whites can still count on appeals to powers outside the municipality to see to their political needs. Some Whites would, however, move to other states, particularly those who either disliked the very idea of living under a majority-Black governing regime, or who were apprehensive about the kinds of policies that would be pursued by such a regime.

Even though a massive White exodus would not be an expected outcome, it is likely that fewer Whites would be willing into migrate into a majority-Black state. However, a state is a far cry from a suburb, and even a small state would offer plentiful opportunities for Whites who wish to live among other Whites, in a town or city with a majority-White local government. A majority-Black state, however, would not provide opportunities for Whites to live under a majority-White state government. Whites who did choose to move to a majority-Black state would therefore be those who were undeterred by the idea of living under majority-Black governance. The GSS data 
discussed in Chapter 4 tends to support the contention that some Blacks would likely migrate in order to live in a majority-Black state on the assumption that the policies enacted by a majority-Black government would benefit Black residents. It is also likely that Black population growth through new births would generally continue to outpace White population growth through new births, as is projected by the U.S. Census. These factors point to the likelihood that once the Black population was to achieve a majority within a state, Blacks would remain in the majority in that state.

Those Whites who would leave a state because they are unwilling to live under a Black government or the policies they expect of such a government are likely to be among the most conservative members of the group. Their departure is liable to have the effect of making the target state more liberal in the nature of the Whites who remain, and may tend to make the surrounding states decidedly more conservative, especially if Whites are moving into the same states from which a large number of Blacks have recently emigrated. This result would probably be most profound in a very conservative state with a history of racial conflict, like Mississippi or Alabama. Given the very large number of Blacks that would have to move into a larger state like Georgia, Virginia, or North Carolina to establish a majority, a movement focused on such a state would also likely reduce Black populations in neighboring states enough to have a significant impact. In states like Delaware and Rhode Island, however, which are both very small and more liberal in the views generally expressed by their White residents, a smaller proportion of Whites would be likely to emigrate. At the same time, the low overall population of these states would minimize the impact that the transition to a Black majority would have on the racial balance of state populations elsewhere. 
The relationship between a Black population moving towards majority status and the White population moving towards becoming the minority within a state would likely parallel the relations between similarly situated groups in counties, municipalities and in congressional districts. The nature of such a relationship would depend to some degree on the history of relations in the geographic area under consideration. As has been previously noted, when Blacks became a significant proportion of the population in Northern cities, the tendency of the existing White political organizations was to bring some Blacks into their power structure, although Black representation in these organizations may have been far more symbolic than substantive. In Southern cities, where the stigma of interracial relations has carried much greater force since the time of slavery, the tendency was disenfranchisement of Black voters, manipulation of political boundaries to minimize even symbolic Black representation, and disempowerment of Black elected officials to minimize substantive representation.

Even in the South, however, this has not always been the case, particularly in recent decades when it has become increasingly difficult to support the ends of racism through any means. Through coalition politics, a significantly increasing Black proportion of the population in a state might first have a moderating effect on the politics of White statewide officials before leading to ascendance of Black officials in those positions. Perry (1997) states: "Like blacks in Birmingham, a growing number of black voters in New Orleans in coalition with middle-class whites played an increasingly important role in the election of the city's first racially moderate white mayor, first racially liberal white mayor, and first black mayor” (p. 183). Neither does a growing Black population mean that Black residents will immediately abandon liberal Whites in 
circumstances where Black support for a Black candidate might take enough votes from a liberal White candidate to hand an election to a conservative White candidate. Keiser (1997) notes that in Philadelphia's 1979 mayoral race, Blacks split their votes between Black candidate Lucien Blackwell and White liberal Bill Green, giving Green enough support to defeat the White conservative candidate, David Marston. He states that because of "the history of mutually advantageous cooperation and coalition formation between middle-class white liberals and blacks, lining up behind Green was not perceived by blacks as 'selling out.' Rather, it yielded a black managing director, and brought blacks one step closer to the mayor's office" (p. 74).

However, once a solid Black majority has been reached, it is likely that Black support for non-Black candidates would dwindle in favor of support for Black candidates. Swain (1995) describes how "White politicians, regardless of how well they have represented their black constituents and no matter how long their tenure, have found themselves under increasing pressure to step aside whenever their political units have been redrawn to have black majorities or when demographic change has altered their district's racial majority" (p. 170). Lavender (1994) discusses how voter turnout decreases among Whites living in cities or districts that become minority-majority areas. In such cases, he explains, White voters are less likely to vote when they only have minority candidates to choose from.

Such a shift, however, does not mean that Whites would entirely lose their influence in the election of public officials. White political influence will be less apparent than in a majority-White state, but several factors will allow Whites to continue to influence the election of candidates of their preference, and the policies endorsed by 
those who are elected. Canon (1999) points this out in his discussion of the majorityBlack congressional districts created following the 1990 Census. He states that "though it was unlikely that whites would win in the new black majority districts, the diversity of black candidates running in 1992 placed white voters in a potentially pivotal position in terms of deciding the type of candidate who won. A relatively cohesive minority can usually help elect their preferred candidate when the majority is divided" (p. 96). Similarly, Whelan and Young (1991) note that the "results of the 1986 mayoral election [of New Orleans] suggest that the white vote played the same role that the black vote played [as a swing-vote] in the 1960s and 1970s, when it was the minority component of the electorate" (p. 141).

A dramatic example of the effects of an ethnic succession from a White governing regime to a Black governing regime occurred much more recently, in Gadsden County, Florida. Although Gadsden County has had a majority of Black residents for decades, Whites "held a vise grip on Gadsden politics until the mid-1990s" (Steinback, 2002). It is only in the past few years that this Black majority in the population has translated to Black control of the local government. Steinback (2002) writes that "three years ago, Gadsden County nearly erupted during a tense, bitter transition to black political power that swept away virtually every white administrator in Quincy in favor of a largely untested phalanx of black replacements." Whites were concerned that the Black governing regime would use it power to exact revenge for a previous era of "virtual apartheid" in the region, where Whites were reportedly unresponsive to Black concerns, and "difficulties thus have fallen disproportionally on its black residents." In 1998, Steinback (2002) reports "the commission majority began to assert itself -- seemingly 
confirming the fears of white residents" of Black reprisals, when the "city manager and city attorney, both white, were fired. The police and fire chiefs, both white, resigned. All their replacements were black."

However, despite this tumultuous start, several years into the existence of the Black governing regime, Whites have become reassured that Blacks are not seeking revenge. Steinback (2002) asserts that "Gadsden's rising black leaders" are now seeking to "set right the disparities wrought by generations of white minority leadership -without alienating today's white residents." The continuing political reprisals feared by Whites have not occurred, and the governing regime has instead focused on making improvements "all around the city" and not just in Black areas. "In a county where both white and black residents have deep roots," Steinback (2002) concludes, "making progress has triumphed over getting even."

Black candidates running for office in an area with a majority-Black political constituency and a large white minority - whether this area is a city, a county, a congressional district, or a state--must take into account the concerns of White voters, and must address these concerns in their campaigns in order to succeed. This is borne out by Bullock's (1984) assessment that "Black politicians often face the choice of either making biracial appeals in hopes of winning white support or criticizing inequities and promising correctives thereby attracting more votes... Even in Atlanta, with its sizable black majority, blacks unacceptable to whites have difficulty getting elected" (p. 249).

Swain (1995) explains that the Black proportion of a majority-Black district dictates the degree to which Black elected officials must appeal to their White constituents. She states that districts which have historically elected Blacks "seem to be 
the least constraining for black representatives. In most of these districts, large black populations mean that white voters are essentially irrelevant to the election process. The representative alone decides whether or not he or she will represent the district's white minority" (p. 47). Canon (1999) suggests that representatives from such districts will be handicapped in their ability to serve their constituents because "Black representatives who campaigned primarily in the African-American community and see themselves as representing black interests will be less likely to serve in the leadership... and more likely to speak in the language of the politics of difference, focus on racial issues in legislation and committee preferences, and focus their constituency service efforts in the black community" (p. 145).

In recently created majority-Black districts, however, the balance of the population is significantly different, leading Swain (1995) to note that none of these recently created districts "has a black population large enough for the representative to have much of a choice about whether to appeal to white voters: because whites are the swing voters in each of these districts, they are courted assiduously" (p. 74). Whelan and Young (1991) discuss how the concern of Black politicians seeking White votes influences policy decisions. They state that "conservative white homeowners no longer dominate the city [of Atlanta] and its spending patterns. On the other hand, even a black leadership is reluctant to raise taxes for purposes of redistribution" (p. 146). Canon (1999) also remarks that "careful assessment of the nature of representation in these [majority-Black] districts shows that most black members of the U.S. House of Representatives represent their entire district, not just the African-American voters" (xii). Expanding upon this view, he states that "black representatives in Congress operate on a 
continuum of racial representation. The most avid supporters of black interests, such as John Conyers and William Clay, also spend a substantial proportion of their legislative work on issues that are important for all Americans. Likewise, the members of the CBC who are most sensitive to the interests of their white constituents spend substantial amounts of time on black interests" (p. 9). His overall assessment is that the "race of the representative has important implications for the type of representation that is provided to a district with a significant number of black constituents. Black members do a better job of walking the racial tightrope and balancing the distinctive needs of black voters and the general interests of all voters, black and white alike. White members tend to have a more exclusive focus on nonracial issues" (pp. 244-5; italics are author's own).

Just as majority-Black cities and counties must contend with the fact that they are located in majority-White states, a majority-Black state would have to contend with the fact that it is located in a majority-White country. As Canon (1999) explains, "White representatives from districts that are 30-40 percent black can largely ignore their black constituents, and many do. Black representatives from districts that are 30-40 percent white cannot ignore their white constituents because they are operating in an institution that is about 86 percent white and a nation that is 82.5 percent white" (p.13). Even when it becomes clear that Blacks will succeed to majority status, Whites can still count on appeals to powers outside the municipality to see to their political needs.

Another factor that would likely fall in favor of White participation in the political process is institutional wealth. Even in a majority-Black state, Whites will tend to have more institutional wealth due to their historic circumstances. Therefore, White wealth and power will certainly impact which Black candidates are able to succeed, particularly 
for the more powerful offices, such as the Senators and Governor, in which Whites have a higher stake. Thomas and Savitch (1991) suggest that White business interests would have little difficulty aligning with a Black government, if that will help White businesses to succeed financially. He notes that in previous decades, "business groups often obtained their electoral majorities by joining with the white middle class. Today, it is not uncommon for business to form alliances with black constituencies, as occurred in Atlanta and Detroit" (p.12). Fleischmann (1991) also examines this issue as it affected Atlanta, and his conclusion is this:

Black electoral clout... has allowed control of City Hall to pass from white businessmen to a generation of black politicians who matured during the civil rights movement. White business leaders did not respond by abandoning Atlanta. Rather, they forged a new governing coalition with black mayors and City Council members. This transition was far from smooth, and while it did leave some lasting changes in the local policy agenda, the new regime also maintained the commitment of economic and political elites to promoting growth. (p. 105).

While some Whites may initially be leery of Black governance, evidence from majority-Black congressional districts and municipalities indicates that White concerns may be allayed once they become used to living under a Black governing regime. Canon (1999) states: "Theorists and politicians alike were quoted... as arguing that having a black representative can change the preferences of white voters who recognize that their interests can be represented by a black politician. Anecdotal evidence to support this point is plentiful" (p. 51). Grofman et al. (1992) also express this contention, stating that the "best evidence suggests relative constancy of polarization in elections in majoritywhite districts in the deep South... and diminished polarization on the part of whites in majority-black areas as voters accept the fact that the winner will be black and as they 
experience the reality that black elected officials are not as undesirable as they might have previously feared" (p. 132).

The issue of redistricting within a majority-Black state raises some interesting legal questions. In particular, the question might be raised as to whether or not a majority-Black state with a sizable White population would be required to create any majority-White districts at all. The elements of the Voting Rights Act which deal with redistricting have been interpreted towards protecting minority groups from being disenfranchised by the machinations of the majority. However, because the standards applied to this protection require that the minority group consistently votes as a bloc, and in doing so are unable to elect the candidate of their choice, it remains to be seen as to whether or not Whites would be considered a minority in need of protection in a state where another group constituted a majority of the population. As Carol Swain notes, "thus far, the Supreme Court has not been sympathetic to the pleas of white voters who complain about racial gerrymanders that crack and stack their populations in order to make way for minority districts" (p. 200). Black leaders responsible for crafting districts in a majority-Black state could effectively skirt this question and preempt the issue of White representation by creating a sufficient number of majority-White districts to accommodate the White population and satisfy potential burdens that might be imposed by the Voting Rights Act.

Through careful designation of boundaries, however, the majority-Black legislature could aid their own cause in a number of ways, by employing the same cracking, stacking and packing techniques that have previously been used to dilute Black voting power. First, they could 'pack' a single overwhelmingly White district, thus 
reducing the influence of White voters in all remaining Black districts. Second, they could isolate wealthier suburban Whites, who may tend to be least sympathetic to Black interests, by 'stacking' them in districts with a sizable Black majority, thus ensuring that any White districts would have a majority of liberal Whites who were more sympathetic to Black issues. Even if the Voting Rights Act were to be interpreted as requiring the creation of a majority-White district, it could not necessitate that such a district be constructed to the benefit of candidates of a particular ideology.

\section{Potential Effects on Party Loyalty and Affiliation}

Black loyalty to the Democratic Party is longstanding and well documented. Barker et al. (1995) state that, because of "major differences between the parties on civil rights and racial issues... the vast majority of blacks became Democrats" (p. 222). Feagin and Sikes (1994) also note that since the 1960s "the Republican Party's stance on civil rights issues has been perceived by a majority of African Americans as retrogressive and inimical to black interests. The historical evidence, though not yet compiled in a systematic way, seems supportive of their view" (p. 325). GSS data also supports this understanding of Black party loyalty. One GSS question asks, "Which party, the Republican or the Democratic, do you feel will do more to help blacks in the next few years, or do you think there isn't much difference between the two?" Of 486 Black respondents, $69.1 \%$ indicated that they felt the Democratic Party would do more to help 
Blacks, while a mere $1.6 \%$ felt that the Republican Party would do more, and only $29.2 \%$ felt that there was not much difference.

As a result of these factors, it is easy to understand why Blacks have given such overwhelming support to the Democratic Party since the 1960s, generally voting for Democratic candidates at both the state and federal levels. Frymer (1999) argues that this consistent loyalty has actually done more harm than good to Blacks seeking substantive representation. He asserts that throughout history, "the desire of political parties to elect candidates to national office has meant marginalization for African Americans" (p. 6). He further claims that "contrary to the beliefs of those who argue that the mere presence of liberal African Americans is sufficient for pushing parties closer to their interests (and thereby for representing their interests), rational party actors will try to move their organization farther to the right on the political spectrum" (p. 25), concluding that the "Democratic party and its strategists focus almost exclusively on swing voters (among those considered likely to vote) who lie in between the parties. In the effort to attract swing voters, they all but ignore captured voters” (p. 127).

The strength of Black loyalty to the Democratic Party, and the apparent disinterest of the Republican Party both point to the probability that Blacks in a majority-Black state will retain their support for the Democratic Party. This analysis is supported by the experience of majority Black municipalities and congressional districts. In every case, majority-Black congressional districts have elected Democrats to the Congress. In fact, the only two Black Republicans elected to the House of Representatives in the past halfcentury have both come from congressional districts that were overwhelmingly White. 
Frymer (1999) also notes that, despite the success of majority-minority districts in securing minority representation in the House of Representatives, "the national majority on various legislative matters is still centered around white voters, and majorities can be found without the need to appeal to congressional members representing majority-black districts" (p. 198). This analysis suggests that even an entire state could be marginalized in its impact on the nation, if the voting majorities can be secured in Congress and in the Senate without the support of that state's representatives. However, given the significant power accorded to members of the Senate, the presence of Black senators will make it much less likely that members of that body-including Republicans, but particularly Democrats-will continuously seek to pass initiatives without garnering the support of the Black members of that body. Furthermore, the successful enactment of Democratic policies in a majority-Black state would benefit the Democratic Party nationally, enhancing the value of such a state to the party, thus encouraging support by the party for the success of policies enacted in that state.

Frymer (1999), however, cautions that Blacks may not necessarily succeed in having their concerns met merely by reliance on the existing political system. "As long as the median voter in the United States maintains ambivalent-to-conservative views toward African American political interests," he cautions, "the two-party system will fail to represent all interests democratically. For black interests to be addressed seriously by the party system, either black political leaders must reshape national public opinion or we must devise an electoral system that provides incentives for parties to appeal to black voters and win elections at the same time" (p. 48). 


\section{Potential Internal Leadership Conflicts}

The development of a politically unassailable Black majority hardly ensures the end of all political strife within a state. Instead, the competition for power is likely to become internalized within the Black community. For example, Barker et al. (1995) describe the aftermath of the consolidation of Black power through their majority status in Greene County Alabama, beginning in the mid 1980s. They report that "in the absence of a white challenge, the unity that characterized earlier black political efforts quickly dissipated and competing black factions soon surfaced. By 1997 black factions were accusing each other of voter fraud and other political and moral indiscretions" (p. 82). It is interesting as an historical aside to observe that even Blacks in Reconstruction-era legislatures were not necessarily monolithic in their politics. Vincent (1976) describes how personality disputes and political disharmony resulted in Blacks from different factions of the Republican Party throwing their support behind different White gubernatorial candidates. In this case, political circumstances "soon disclosed that blacks were far from united... the struggle for political supremacy found blacks on both sides" (p. 135).

Canon (1999), however, does note that although "black interests, and the political expression of those interests, are by no means monolithic, they are far more cohesive than those of any other racial or ethnic minority in the United States. African Americans vote more cohesively and demonstrate more consistent political opinions (on racial and partracial issues) than Hispanics, Asian Americans, Jews, or other racial or ethnic groups" (pp. 32-33). 
Where Blacks are in the majority, Black elected officials tend to come from the Black elite - the wealthiest and most educated segments of the Black community-which directly parallels the White political experience. Frymer (1999) notes: "Scholars have pointed to diversity among African Americans-for instance, a growing middle class and occupational, intellectual, and cultural heterogeneity-and they claim that the more important determinant of individual identity among African Americans is economic background" (p. 146). Stone and Pierannunzi (1997) state somewhat more dramatically that there exists "a fault line within the African-American community between haves and have-nots, but its reflection in electoral politics is quite weak" (p. 167). The key result of this disparity, they assert, "is the low level of voter participation, especially among the younger generation of African Americans. Atlanta's urban regime is therefore built around accommodations principally between the black middle class and white business elites” (p. 167). Perry (1997) also notes this sentiment, stating:

An increasing criticism of black politics is that the benefits produced by increasing black political incorporation have gone to members of the black middle class who possessed the educational, occupational, and social skills necessary to take advantage of the new opportunities... The irony is that the increased black political participation and influence in cities in the 1970 s and 1980s is in large part a result of the entry of a significantly larger proportion of the black lower class into electoral politics, and their political awakening was often stimulated by the prospecting of electing a viable black candidate to a high-level political office. (p. 189).

Divisions within the Black community could also develop around issues beyond class structure. Orr (1997) notes, for example, that in Baltimore in the 1970s, "the most important ideological division was between machine-style black politicians and those black leaders whose roots were in the civil rights movement" (p. 205). It is also 
important to note that Blacks who would be willing to move to a different state for the specific purpose of securing greater political power would probably be more politically active than the typical Black population, and it is certainly possible that the participants in such a migration would include some Blacks with Nationalist or Separatist views. At the same time, however, a majority-Black state without the onus of White government impeding the ability of Blacks to address issues as they wish, would likely serve as a catalyst for more open expression of conservative Black points of view. In other words, the entire spectrum of Black political thought, from the most radical ideas to the most conservative, would likely be freely expressed within a state where a majority-Black governing regime was solidified.

\section{Pressures of Governing Under the National Microscope}

One unique problem that is likely to face the government of a majority-Black state is the likelihood that this government will face exceptional scrutiny. Some will hope that a majority-Black government proves capable of handling the typical problems associated with the management of a state flawlessly and gracefully; others will expect it to fail dramatically. Concern about the expectation of failure is conveyed by Florida State Representative Curtis Richardson, who represents an area which includes Gadsden County. Richardson fears that "people look at them and say, 'Black folks running things,' and automatically assume there will be chaos" (Steinback, 2002). 
Stone and Pierannunzi (1997) describe a particular situation in which the attention focused on majority-Black governance created difficulties for the governing regime:

In Atlanta in the 1970s, the situation was further complicated by the high expectations surrounding black control of the school system. To acknowledge publicly that low academic achievement was not amenable to the quick fix of a change in the racial control of school administration would be risky; administrators might be seen as admitting failure. As it turned out, not acknowledging the problem and instead promoting "an aura of success" carried an even greater hazard - that of breeding cynicism and opportunism within the school system. (p. 173).

The example of the Atlanta school system highlights the simple fact that the most likely outcome is that a majority-Black state government will face the same challenges, successes, and failures that every state government deals with regularly. While every government must contend with some policy failures and some degree of corruption among government officials, a majority-Black government would undoubtedly wish to avoid these pitfalls for fear that Whites who were ideologically opposed to Black aims would latch onto them as justification for the maintenance of discriminatory policies. Inevitably, some failures will occur and some corruption will be unearthed, leading to the feared outcome. However, greater problems would inevitably arise from efforts to cover up problems in order to avoid the stigma associated with the experience of typical governmental problems. 


\section{The Effect on the Nation as a Whole}

The existence of a majority-Black state would necessarily affect the politics of the entire nation. To begin with, the permanent presence of two Black-elected Senators would give Blacks clout in that body which could not be ignored, even if the support of Black senators could be bypassed on some issues (as can the support of any individual White Senator). But the more profound effect would be in the presentation of the Black leaders of a majority-Black state as role models for the Black population, and as examples of Blacks exercising a high level of political power to the White population. Perry (1997) states that "the election of blacks to high positions of public responsibility not only benefits blacks generally by improving their individual and group self-esteem but also makes it easier for whites to accept blacks in other positions of public responsibility. Thus, the benefits that blacks have achieved in the symbolic realm have substantially improved their social status" (p. 196). Clayton (2000) notes the comparable opportunity that majority-minority districts present, stating that the "creation of majorityminority districts is a practical but temporary solution to a complex problem. ...Majority black districts can serve as a staging grounds for blacks entering the political arena. By creating majority-minority districts, blacks and other minorities can show the majority that they have the ability and integrity to represent all Americans" (p. 129).

Despite the power that would be inherent in the control of a state, the Black polity would have to be prepared to deal with the necessary relationship between political power and business and economic forces. Control of a state would give the Black population therein the opportunity to experiment with different policy approaches, but the 
stark reality of the need to raise revenues and make hard decisions on their expenditure would likely end up having a moderating effect on the desire for immediate and complete social and economic change. Lusane (1994) asserts that "economic development and power in the United States, as well as the distribution of social and cultural norms, is rooted in political power and public policy" (p. 39). Stone and Pierannunzi (1997), however, note that "Governance comes out of the interplay between electoral and economic power. Neither stands alone. Governance... requires cooperation and accommodation among a network of institutions, especially political and economic ones" (p. 166; italics are author's own). Orr (1997) agrees with the latter sentiment, stating that "electoral control alone does not secure inclusion in the mainstream economy. Something more is needed. Black urban regimes must establish strong links with massbased political/civic organizations, business leaders, nonprofits, and other nongovernmental institutions" (p. 217).

Perry (1997), discussing majority-Black municipal advances, sums up the ultimate hopes of this strategy:

The benefits that blacks have received from their increased political power and ... have been both symbolic and substantive... Increased black political participation and especially increased black officeholding have moved the black populace towards enhanced group social standing, which concomitantly has elevated black's self-esteem. A derivative of the symbolic benefits that ensue from blacks holding important governmental positions is that it becomes easier for other blacks to move into important positions of public responsibility. (p. 195). 


\section{CHAPTER V.}

\section{Conclusions}

The superior political status of Whites combined with disenfranchisement which Blacks experienced prior to the passage of the Voting Rights Act of 1965 prevented geographic relocation from succeeding as a strategy for Black political empowerment. Present day social conditions are far more conducive to the success of such a venture, and an examination of the migration that would need to be undertaken reveals that a settlement strategy is logistically possible in several states. The most likely state for success would be Delaware, based on the relatively small number of Blacks who would have to move to that state combined with a convenient location relative to the traditional corridors of migration and several Northern cities with large Black populations.

Having two Senators elected by Blacks would provide the Black community with substantively and symbolically powerful issue advocacy and voting power within the Senate, which is organized in a way that provides its members with more relative power than Representatives enjoy in the House. A majority-Black state government would also control redistricting, election procedures, and felony disenfranchisement laws, and would have the power to enact policies generally preferred by the Black community. These additional resources under the control of a Black population would likely enhance the influence of Blacks within the Democratic Party. Perhaps the greatest value, however, of the presence of a Black Senator or Governor is simply the symbolic message that Blacks are capable of holding such offices; that they are intelligent enough, talented enough, good enough to sit at the table of power now dominated by Whites. 
There are many avenues for further research that could be conducted regarding this concept. A much more detailed analysis might seek to determine which locations Blacks should move away from, in order to salvage electoral potential that is currently being wasted. It would make political sense for Blacks to leave those areas where Black votes are routinely over-ridden by White votes for candidates generally opposed by Black voters. More concise determinations could also be made of the cost of carrying out such a strategy based on the expenses associated with relocation, and with the establishment of new communities at the point of destination. Analysis could be done of the impact that Black social and economic institutions could have in support of such a strategy, and on how it would effect these institutions within the target state.

Because this idea has not been popularly discussed in American society, there is no way to evaluate the general impression which people will have of this strategy within the context of the possibility of success described here. Most of the people with whom I discussed this potential strategy were surprised to find that the number of Black citizens who would need to relocate to establish a majority in certain states was far lower than they would initially have assumed. The possibility, slight as it may be, that a majorityBlack state could eventually develop as an unintended consequence of current population trends is equally intriguing. If this idea were to find an outlet by which it could be popularly discussed-and if the logistical possibilities were to be made generally known - then further research could be conducted in the assessment of this strategy by informed Black and White respondents. 


\section{REFERENCES}

Aberbach, Joel D. and Jack L. Walker. (1972[1970]). "Political Trust and Racial Ideology.” Pp. 133-62 in Black Political Attitudes, Charles Bullock III and Harrell R. Rodgers Jr., eds. Chicago, IL: Markham Publishing Company.

Abraham, Kinfe. (1991). Politics of Black Nationalism. Trenton, NJ: Africa World Press, Inc.

Adero, Malaika. (1993). Up South: Studies and Letters of this Century's AfricanAmerican Migrations. NY: The Free Press.

Agresti, Alan, and Barbara Finlay. (1997). Statistical Methods for the Social Sciences, Third Edition. Upper Saddle River, NJ: Prentice Hall, Inc.

Andrews, Kenneth T. (1997). "The Impacts of Social Movements on the Political Process: The Civil Rights Movement and Black Electoral Politics in Mississippi." American Sociological Review. 62:800-19.

Appleby, Joyce. (2000). Inheriting the Revolution. Cambridge, MA: Harvard University Press.

Ardleigh, Kathy. GOP, Dems See Chance at Oregon Governor's Spot. Fox News at $<$ http://www.foxnews.com/story/0,2933,53087,00.html $>$ Friday, May 17, 2002

Baker, Ross K. (2001) House and Senate, Third Edition. NY: W.W. Norton and Co.

Barker, Lucius J., Mack H. Jones and Katherine Tate. (1999). African Americans and the American Political System, Fourth Edition. Upper Saddle River, NJ: Simon and Schuster.

Barone, Michael, Richard E. Cohen and Grant Ujifusa, eds. (2002). The Almanac of American Politics 2002. Washington, D.C: National Journal.

Bearman, Peter S., and Hyojoung Kim. (1997). "The Structure and Dynamics of Movement Participation." American Sociological Review. 62:70-93.

Bennett Jr., Lerone. (2000 [1992]). "10 Most Dramatic Events In African-American History." Pp. 110-4 in Annual Editions: Race and Ethnic Relations 00/01, edited by John A. Kromkowski. Guilford, CT: Dushkin/McGraw-Hill.

Berry, Mary F. and John W. Blassingame. (1992 [1982]). "Blacks and the Politics of Redemption." Pp 597-634 in A Turbulent Voyage: Readings in African American studies, edited by Floyd W. Hayes III. San Diego, CA: Collegiate Press. 
Black, Earl and Merle Black. (1992). The Vital South: How Presidents Are Elected. Cambridge, MA: Harvard University Press.

Bobo, Lawrence, John J. Hetts, David O. Sears and Jim Sidanius. (2000). "Race in American Politics: Framing the Debates." Pp. 1-43 in Racialized Politics edited by Lawrence Bobo, David O. Sears, and Jim Sidanius. Chicago, IL: University of Chicago Press.

Bodovitz, Kathy. (2000 [1991]). "Black America." Pp. 115-6 in Annual Editions: Race and Ethnic Relations 00/01, edited by John A. Kromkowski. Guilford, CT: Dushkin/McGraw-Hill.

Bonilla-Silva, Eduardo. (1997). "Rethinking Racism: Towards a Structural Interpretation." American Sociological Review. 62:465-80.

Bositas, David A. (2000) "Black Elected Officials: A statistical summary, 2000." Report of the Joint Center for Political and Economic Studies, Washington, DC.

Bridges, Amy and Katherine Underwood. (2000). "Life After Districts." Pp 51-57 in Minority Politics at the Millennium, edited by Richard A. Keiser and Katherine Underwood. NY: Garland Publishing.

Browning, Rufus P., Dale Rogers Marshall and David H. Tabb. (1997). "Can People of Color Achieve Power in City Government? The Setting and the Issues." Pp 3-14 in Racial Politics in American Cities, edited by Rufus P. Browning, Dale Rogers Marshall and David H. Tabb. White Plains, NY: Longman Publishers.

Browning, Rufus P., Dale Rogers Marshall and David H. Tabb. (1997). "Has Political Incorporation Been Achieved? Is It Enough?" Pp 277-99 in Racial Politics in American Cities, edited by Rufus P. Browning, Dale Rogers Marshall and David H. Tabb. White Plains, NY: Longman Publishers.

Browning, Rufus P., Dale Rogers Marshall and David H. Tabb. (2000). "Taken In or Just Taken? Political Incorporation of African Americans in Cities." Pp 131-156 in Minority Politics at the Millennium, edited by Richard A. Keiser and Katherine Underwood. NY: Garland Publishing.

Bullock, Charles S., III. (1984). "Racial Crossover Voting and the Election of Black Officials." Journal of Politics. 46:238-51.

Bullock, Charles S. III and Loch K. Johnson. (1992). Runoff Elections in the United States. Chapel Hill, NC: University of North Carolina Press. 
Campbell, Paul R., (1996). Population Projections for States by Age, Sex, Race, and Hispanic Origin: 1995 to 2025, U.S. Bureau of the Census, Population Division, PPL-47.

Cancio, A. Silvia, T. David Evans and David J. Maume, Jr. (1996). "Reconsidering the Declining Significance of Race: Racial Differences in Early Career Wages." American Sociological Review. 61:541-56.

Canon, David T. (1999). Race, Redistricting, and Representation: The Unintended Consequences of Black Majority Districts. Chicago, IL: University of Chicago Press.

Cassidy, Rachel C. and Elizabeth M. Grieco. (2001). "Overview of Race and Hispanic Origin: 2000." Report of the United States Bureau of the Census issued March, 2001 at $<$ http://www.Census.gov $>$. Washington, D.C.

Civil Rights Action Center. (2002). <http://capwiz.com/civilrights/issues/votes/> (August 1, 2002)

Clayton, Dewey M. (2000). African Americans and the Politics of Congressional Redistricting. NY: Garland Publishing, Inc.

Cohen, Raymond. (1997). Negotiating Across Cultures: International Communication in an Interdependent World. Washington, D.C: United States Institute of Peace Press.

Cohn, D'Vera. "Jobs, family ties bringing blacks back to the South." The Miami Herald, May 6, 2001, 3A.

Cole, David. (2000 [1999]). "The Color of Justice." Pp. 120-1 in Annual Editions: Race and Ethnic Relations 00/01, edited by John A. Kromkowski. Guilford, CT: Dushkin/McGraw-Hill.

Cose, Ellis. (1998 [1996]). "Color Blind." Pp. $244-8$ in Annual Editions: Race and Ethnic Relations 98/99, edited by John A. Kromkowski. Guilford, CT: Dushkin/McGraw-Hill.

Coser, Lewis. (1964). The Functions of Social Conflict. NY: The Free Press.

Dahl, Robert A. (1956). A Preface to Democratic Theory. Chicago, IL: University of Chicago Press.

Danigelis, Nicholas L. (1977). "A Theory of Black Political Participation in the United States." Social Forces. 56:31-47.

Davis, F. James. (1991). Who Is Black? One nation's definition. University Park, PA: The Pennsylvania State University. 
Du Bois, W.E.B. (1989 [1903]) The Souls of Black Folk. NY: Bantam.

Elder, Larry. (2000). The Ten Things You Can't Say in America. NY: St. Martin's Press.

Early, Gerald. (1998 [1996]). "Understanding Integration." Pp. 126-33 in Annual Editions: Race and Ethnic Relations 98/99, edited by John A. Kromkowski. Guilford, CT: Dushkin/McGraw-Hill.

Edgar, Walter. (1998). South Carolina: A History. Columbia, SC: University of South Carolina Press.

Ellis, Richard J. (1993). American Political Cultures. NY: Oxford University Press.

Engstrom, Richard L. (2000). "Electoral Arrangements and Minority Political Incorporation." Pp 19-50 in Minority Politics at the Millennium, edited by Richard A. Keiser and Katherine Underwood. NY: Garland Publishing.

Feagin, Joe R. and Melvin P. Sikes. (1994). Living With Racism: The Black MiddleClass Experience. Boston, MA: Beacon Press.

Feagin, Joe R. and Robert E. Parker. (1991). "Houston: Administration by Economic Elites." Pp 169-188 in Big City Politics in Transition, edited by H.V. Savitch and John Clayton Thomas. Newbury Park, CA: Sage Publications.

Fearon, James D. and David D. Laitin. (1996). "Explaining Interethnic Cooperation." American Political Science Review. 90:715-35.

Fellner, Jamie. (1998) "Losing the Vote: The Impact of Felony Disenfranchisement Laws in the United States." Report of Human Rights Watch issued October 1998 at $<$ http://www.hrw.org/reports98/vote/>

Fiscus, Ronald J. (1992). The Constitutional Logic of Affirmative Action: Making the Case for Quotas. Durham, NC: Duke University Press.

Fleischmann, Arnold. (1991). "Atlanta: Urban Coalitions in a Suburban Sea." Pp 97114 in Big City Politics in Transition, edited by H.V. Savitch and John Clayton Thomas. Newbury Park, CA: Sage Publications.

Fleischmann, Arnold. (2000). "Can Cities Be Elastic and Democratic, Too?." Pp 10929 in Minority Politics at the Millennium, edited by Richard A. Keiser and Katherine Underwood. NY: Garland Publishing.

Fletcher, Michael A. "New Tolerance in the South or Old Power of Incumbency?" The Washington Post, November 23, 1996, A1, A6. 
Foreman, Jr., Christopher H. (2000 [1998]). "Black America: The Rough Road to Racial Uplift." Pp. 22-4 in Annual Editions: Race and Ethnic Relations 00/01, edited by John A. Kromkowski. Guilford, CT: Dushkin/McGraw-Hill.

Frazier, Stephen. Census figures look bad for Republicans. TNA News with Commentary, www.newaus.com.au/us230stephen.html, Thursday, April 26, 2001

Frazier, Stephen. Hispanic power increasing exponentially. TNA News with Commentary, www.newaus.com.au/us239stephen.html, Saturday, May 12, 2001.

Fredrickson, George M. (1999). “America's Caste System: Will It Change?” Pp. 13443 in Annual Editions: Race and Ethnic Relations 98/99, edited by John A. Kromkowski. Guilford, CT: Dushkin/McGraw-Hill.

Frymer, Paul. (1999). Uneasy Alliances: Race and Party Competition in America. Princeton, NJ: Princeton University Press.

Gehman, Mary. (1994). The Free People of Color of New Orleans: An Introduction. New Orleans, LA: Margaret Media, Inc.

Giles, Michael W. and Kaenan Hertz. (1994). "Racial Threat and Partisan Identification." American Political Science Review. 88:317-26.

Gillette, William. (1979). Retreat From Reconstruction. 1869-1879. Baton Rouge, LA: Louisiana State University Press.

Glassberg, Andrew D. (1991). "St. Louis: Racial Transition and Economic Development." Pp 86-96 in Big City Politics in Transition, edited by H.V. Savitch and John Clayton Thomas. Newbury Park, CA: Sage Publications.

Grofman, Bernard; Lisa Handley and Richard G. Niemi. (1992). Minority Representation and the Quest for Voting Equality. NY: Cambridge University Press.

Hendrickson, Paul. (2000 [1999]). "Unsealing Mississippi's Past." Pp. 160-8 in Annual Editions: Race and Ethnic Relations 00/01, edited by John A. Kromkowski. Guilford, CT: Dushkin/McGraw-Hill.

Hill, Kevin A. (1995). "Does the Creation of Majority Black Districts Aid Republicans?" An Analysis of the 1992 Congressional Elections in Eight Southern States." Journal of Politics. 57:384-401

Hocker, Joyce L. and William W. Wilmot. (2001). Interpersonal Conflict, Sixth Edition. McGraw-Hill Higher Education. NY.

Horner, Louise L., ed. (1998). Black Americans: a Statistical Sourcebook. Palo Alto, CA: Information Publications. 
Horton, Carrell P., and Jessie Carney Smith, eds. (1997). Statistical Record of Black America, Fourth Edition. Detroit, MI: Gale Publishing.

Hughes, Michael and Melvin E. Thomas. (1998). "The Continuing Significance of Race Revisited: A Study of Race, Class, and Quality of Life in America, 1972 to 1996." American Sociological Review. 63:785-95.

Human Rights Watch. "US Election 2000: Losing the Vote: The Impact of Felony Disenfranchisement Laws." November 8, 2000.

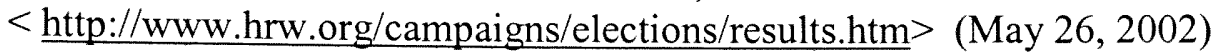

Human Rights Watch. "Race and Incarceration in the United States - A Human Rights Watch Press Backgrounder." February 27, 2002.

$<$ http://www.hrw.org/backgrounder/usa/race/> (April 27, 2002)

Hunter, James Davison. (1991). Culture Wars: The Struggle to Define America. NY: Basic Books.

John-Hall, Annette. "Reparations now widely debated." The Miami Herald, April 15, 2001, 3L.

Keiser, Richard A. (1997). "After the First Black Mayor: Fault Lines in Philadelphia's Biracial Coalition." Pp 65-93 in Racial Politics in American Cities, edited by Rufus P. Browning, Dale Rogers Marshall and David H. Tabb. White Plains, NY: Longman Publishers.

Keiser, Richard A. (2000). "The Changing Structure of Minority Group Political Opportunities: Looking Ahead to the Twenty-first Century." Pp 1-18 in Minority Politics at the Millennium, edited by Richard A. Keiser and Katherine Underwood. NY: Garland Publishing.

Keiser, Richard A. (2000). "Analyzing Urban Regime Change: Black Power, White Backlash, and Shades of Gray." Pp 157-77 in Minority Politics at the Millennium, edited by Richard A. Keiser and Katherine Underwood. NY: Garland Publishing.

Kiely, Kathy. "Nation's elite political circles lack minorities." USA Today Newspaper. January 21, 2002, 1 A.

King, Jr., Martin Luther. (1992 [1963]). "Letter from a Birmingham Jail.” Pp. 113-28 in A Peace Reader, Joseph J. Fahey and Richard Armstrong, eds. Mahwah, NJ: Paulist Press.

Koger, Larry. (1995). Black Slaveowners: Free Black Slave Masters in South Carolina, 1790-1860. Columbia, SC: University of South Carolina Press. 
Kromkowski, John A. (2000 [1997]). "American Ethnicities and the Politics of Inclusion, Part I." Pp. 213-9 in Annual Editions: Race and Ethnic Relations 00/01, edited by John A. Kromkowski. Guilford, CT: Dushkin/McGraw-Hill.

Ladner, Joyce. (1967). "What Black Power Means to Negroes in Mississippi." Pp. 85108 in The Changing South, edited by Raymond W. Mack. USA: Aldine Publishing Company.

Lavender, Abraham. (2000). "Responses to Discrimination: Significance for Intergroup Relations." Pp. 315-7 in Racial and Ethnic Relations in America, edited by Carl L. Bankston III, et al. Pasadena, CA: Salem Press.

Lavender, Abraham. (2000). "The One Drop Rule: History of United States Definitions of Race." P. 742 in Racial and Ethnic Relations in America, edited by Carl L. Bankston III, et al. Pasadena, CA: Salem Press.

Lavender, Abraham. (1996). "At-Large Elections: Effects on African-American Candidates." Pp. 1839-1841 in The African American Encyclopedia. Pasadena, CA: Salem Press.

Lavender, Abraham. (1994). "The Effect of Court-Ordered Voter Redistricting on Voter Turnout and Ethnic Candidates." Presented at the annual meeting of the American Sociological Association, August $8^{\text {th }}$, Los Angeles, CA.

Lee, Frances E., and Bruce I. Oppenheimer. (1999). Sizing Up the Senate. Chicago, IL: University of Chicago Press.

Lind, Michael. (2000 [1997]). "The End of the Rainbow: The poverty of racial politics and the future of liberalism." Pp. 208-12 in Annual Editions: Race and Ethnic Relations 00/01, edited by John A. Kromkowski. Guilford, CT: Dushkin/McGraw-Hill.

Lipset, Seymour Martin. (1996). American Exceptionalism: A Double-Edged Sword. NY: W.W. Norton and Co.

Lusane, Clarence. (1994). African Americans at the Crossroads: The Restructuring of Black Leadership and the 1992 Elections. Boston, MA: South End Press.

Mack, Raymond W. (1963). "Is the White Southerner Ready for Equality?" Pp. 9-20 in The Changing South, edited by Raymond W. Mack. USA: Aldine Publishing Company.

Marshall, Gordon. (1994). The Concise Oxford Dictionary of Sociology. NY: Oxford University Press. 
Mascetti, Kristine Reed. (1998). "White Racial Attitudes in Relation to Black Concentrations." M.A. Thesis, Department of Sociology/Anthropology, Florida International University, Miami, FL.

Mauro, Tony, and Tom Watson. "Court grows critical when race, law intersect." USA Today Newspaper, June 30, 1995, 8A.

McKinnon, Jesse. (2001). "The Black Population: 2000." Report of the United States Bureau of the Census issued August, 2001 at $<$ http://www.Census.gov $>$. Washington, D.C.

Meacham, Jon. (2000). “The New Face of Race.” Newsweek, September 18, p. 38.

Meier, August, and Elliott Rudwick. (1976). From Plantation to Ghetto. NY: Hill and Wang.

Mills, Karen M. (2001). "Congressional Reapportionment." Report of the United States Bureau of the Census issued July, 2001 at $<\underline{\mathrm{http}}$ ://www.Census.gov $>$. Washington, D.C.

Minkoff, Debra C. (1997). “The Sequencing of Social Movements." American Sociological Review. 62:779-99.

Minnerbrook, Scott. (1994 [1993]). "Home Ownership Anchors the Middle Class." Pp. 157-61 in Annual Editions: Race and Ethnic Relations 94/95, edited by John A. Kromkowski. Guilford, CT: Dushkin/McGraw-Hill.

Mladenka, Kenneth R. (1989). "Blacks and Hispanics in Urban Politics." American Political Science Review. 83:165-91.

Morganthau, Tom. (1995) “What Color Is Black?” Newsweek, February 13, pp. 63-5.

Morganthau, Tom. (1997) “The Face of the Future." Newsweek, January 27, pp. 58-60.

Morris, Milton D. (1992 [1975]). "Democratic Politics and Black Subordination." Pp 581-96 in A Turbulent Voyage: Readings in African American studies, edited by Floyd W. Hayes III. San Diego, CA: Collegiate Press.

Olson, Mancur. (1971). The Logic of Collective Action; Public Goods and the Theory of Groups. Cambridge, MA: Harvard University Press.

Orr, Marion. (1997). "The Struggle for Black Empowerment in Baltimore: Electoral Control and Governing Coalitions." Pp 201-19 in Racial Politics in American Cities, edited by Rufus P. Browning, Dale Rogers Marshall and David H. Tabb. White Plains, NY: Longman Publishers. 
Paige, Jeffrey M. (1972[1970]). "Changing Patterns of Anti-White Attitudes Among Blacks." Pp. 97-114 in Black Political Attitudes, Charles Bullock III and Harrell R. Rodgers Jr., eds. Chicago, IL: Markham Publishing Company.

Patillo-McCoy, Mary. (1998). "Black Church Culture as a Community Strategy of Action." American Sociological Review. 63:767-84.

Pattaniak, Prasanta K. (1971). Voting and Collective Choice: Some Aspects of the Theory of Group Decision Making. NY: Cambridge University Press.

Patterson, Orlando. (1997). The Ordeal of Integration. Washington D.C: Civitas/Counterpoint.

Piatt, Bill. (1997). Black and Brown in America. NY: New York University Press.

Perry, Huey L. (1997). "The Evolution and Impact of Biracial Coalitions and Black Mayors in Birmingham and New Orleans." Pp 179-200 in Racial Politics in American Cities, edited by Rufus P. Browning, Dale Rogers Marshall and David H. Tabb. White Plains, NY: Longman Publishers.

Pierannunzi, Carol, and Clarence Stone. (1997). "Atlanta and the Limited Reach of Electoral Control." Pp 163-77 in Racial Politics in American Cities, edited by Rufus P. Browning, Dale Rogers Marshall and David H. Tabb. White Plains, NY: Longman Publishers.

Rae, Nicol C. (1994). Southern Democrats. NY: Oxford University Press.

Reeves, Keith. (1997). Voting Hopes or Fears? White Voters, Black Candidates \& Racial Politics in America. NY: Oxford University Press.

Rich, Wilber. (1991). "Detroit: From Motor City to Service Hub." Pp 64-85 in Big City Politics in Transition, edited by H.V. Savitch and John Clayton Thomas. Newbury Park, CA: Sage Publications.

Roberston, Ian (1987). Sociology. NY: Worth Publishers, Inc.

Robinson, Dean E. (1998 [1997]). "Black Politics, the 1996 Elections, and the End of the Second Reconstruction." Pp. 110-17 in Annual Editions: Race and Ethnic Relations 98/99, edited by John A. Kromkowski. Guilford, CT: Dushkin/McGraw-Hill.

Roscigno, Vincent J., and Donald Tomaskovic-Devey. (1996). "Racial Economic Subordination and White Gain in the U.S. South." American Sociological Review. 61:565-89. 
Rubin, Jeffrey Z., Dean G. Pruitt and Sung Hee Kim. (1994). Social Conflict: Escalation, Stalemate, and Settlement. Second Edition. NY: McGraw-Hill.

Schachter, Jason. (2001). "Geographic Mobility Population Characteristics: March 1999 - March 2000." Report of the United States Bureau of the Census issued May, 2001 at

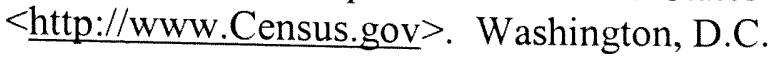

Schachter, Jason. (2001). "Why People Move: Exploring the March 2000 Current Population Survey: March 1999 - March 2000." Report of the United States Bureau of the Census issued May, 2001 at $<$ http://www.Census.gov>. Washington, D.C.

Sears, David O. (1972[1969]). "Black Attitudes Toward the Political System in the Aftermath of the Watts Insurrection." Pp. 115-1 in Black Political Attitudes, Charles Bullock III and Harrell R. Rodgers Jr., eds. Chicago, IL: Markham Publishing Company.

Segal, Ronald. (1995). The Black Diaspora. NY: Farrar, Straus, and Giroux.

Shafer, Byron E. (1991). "We Are All Southern Democrats Now: The Shape of American Politics in the Very Late Twentieth Century." Pp. 147-76 in Present Discontents: American Politics in the Very Late Twentieth Century, edited by Byron E. Shafer. Chatham, NJ: Chatham House Publishers, Inc.

Sharp, Gene. (1992 [1970]). "The Techniques of Nonviolent Action." Pp. 223-9 in $A$ Peace Reader, Joseph J. Fahey and Richard Armstrong, eds. Mahwah, NJ: Paulist Press.

Sharp, Gene. (1992 [1973]). "198 Methods of Nonviolent Action." Pp. $473-9$ in $A$ Peace Reader, Joseph J. Fahey and Richard Armstrong, eds. Mahwah, NJ: Paulist Press.

Singleton, Jr., Royce, and Jonathan H. Turner. (1978). “A Theory of Ethnic Oppression: Toward a Reintegration of Cultural and Structural Concepts in Ethnic Relations Theory." Social Forces. 56:1001-17

Smallwood, Arwin D., and Jeffrey M. Elliot. (1998). The Atlas of African-American History and Politics. Boston, MA: McGraw Hill.

Stack, Carol. (1996). Call to Home: African Americans Reclaim the Rural South. NY: BasicBooks.

Steinback, Robert L. and Alice K. DuPont. "A new balance of power: Florida's only majority-black county makes progress in tackling disparities." The Miami Herald, July $30,2002,1 \mathrm{~B}$.

Sullivan, Lisa Y. (1998 [1997]). "Hip-Hop Nation: The Undeveloped Social Capital of Black Urban America." Pp. 253-6 in Annual Editions: Race and Ethnic Relations 98/99, edited by John A. Kromkowski. Guilford, CT: Dushkin/McGraw-Hill. 
Swain, Carol M. (1995). Black Faces, Black Interests: The Representation of African Americans in Congress. Cambridge, MA: Harvard University Press.

Taylor, Marylee C. (1998). "How White Attitudes Vary With Racial Composition of Local Populations: Numbers Count." American Sociological Review. 63:512-35.

Taylor, Marylee C. (2000). "The Significance of Racial Context." Pp.118-36 in Racialized Politics edited by Lawrence Bobo, David O. Sears, and Jim Sidanius. Chicago, IL: University of Chicago Press.

Thernstrom, Abigail, and Stephan Thernstrom. (2000 [1998]). "Black Progress: How Far We've Come- and How Far We Have to Go." Pp. 25-9 in Annual Editions: Race and Ethnic Relations 00/01, edited by John A. Kromkowski. Guilford, CT: Dushkin/McGraw-Hill.

Thomas, John Clayton and H.V. Savitch. (1991). "Introduction: Big City Politics, Then and Now." Pp 1-13 in Big City Politics in Transition, edited by H.V. Savitch and John Clayton Thomas. Newbury Park, CA: Sage Publications.

Thomas, Norman C., and Harold L. Wolman. (1972 [1970]). "Black Interests, Black Groups, and Black Influence in the Federal Policy Process: The Cases of Housing and Education." Pp. 183-203 in Black Political Attitudes, Charles Bullock III and Harrell R. Rodgers Jr., eds. Chicago, IL: Markham Publishing Company.

Thurber, James, and Roger Davidson. (1995). Remaking Congress: Change and Stability in the 1990's. Washington DC: Congressional Quarterly, Inc.

Timpone, Richard J. (1995). "Mass Mobilization or Government Intervention? The Growth of Black Registration in the South." Journal of Politics. 57:425-42.

Underwood, Katherine. (2000). "A Long and Uncertain Path: Looking Ahead to the Twenty-first Century." Pp 257-76 in Minority Politics at the Millennium, edited by Richard A. Keiser and Katherine Underwood. NY: Garland Publishing.

United States Bureau of the Census. (2002). "Statistical Abstract of the United States." Report of the United States Bureau of the Census issued March, 2001 at $<$ http://www.Census.gov $>$. Washington, D.C..

Vedlitz, Arnold and Charles Johnson. (1982). "Community Racial Segregation, Electoral Structure and Minority Representation." Social Science Quarterly. 63:729-36.

Vincent, Charles. (1976). Black Legislators in Louisiana During Reconstruction. Baton Rouge, LA: Louisiana State University Press. 
Vogel, Ronald K. and Genie N.L. Stowers. (1991). "Miami: Minority Empowerment and Regime Change." Pp 115-131 in Big City Politics in Transition, edited by H.V. Savitch and John Clayton Thomas. Newbury Park, CA: Sage Publications.

Walters, Pamela Barnhouse, David R. James and Holly J. McCammon. (1997). "Citizenship and Racial Inequality in Southern Schools." American Sociological Review. 62:34-52.

Warren, Christopher. (1997). "Hispanic Incorporation and Structural Reform in Miami." Pp. 223-46 in Racial Politics in American Cities, edited by Rufus P. Browning, Dale Rogers Marshall and David H. Tabb. White Plains, NY: Longman Publishers.

Waste, Robert J. (1990). "Regime Politics: Governing Atlanta, 1946-1988." American Political Science Review. 84:1411-12.

Welch, Susan. (1990). "The Impact of At-Large Elections on the Representation of Blacks and Hispanics." Journal of Politics. 52:1051-76.

West, Cornel. (1992). “Assessing Black Neoconservatism." Pp 650-6 in A Turbulent Voyage: Readings in African American studies, edited by Floyd W. Hayes III. San Diego, CA: Collegiate Press.

Whelen, Robert K., and Alma H. Young (1991). "New Orleans: The Ambivalent City." Pp 132-148 in Big City Politics in Transition, edited by H.V. Savitch and John Clayton Thomas. Newbury Park, CA: Sage Publications.

Whittier, Nancy. (1997). "Political Generations, Micro-Cohorts, and the Transformation of Social Movements." American Sociological Review. 62:760-78.

Wilson, Charles Reagan, and William Ferris. (1989). The Encyclopedia of Southern Culture. Chapel Hill, NC: The University of North Carolina Press.

Wood, Peter H. (1974). Black Majority: Negroes in Colonial South Carolina from 1670 through the Stono Rebellion. NY: W.W. Norton and Co.

Worrill, Conrad W. "The Need To Reestablish Black Nationalist Thinking." Report of the Association for the Study of Classical African Civilizations available at $<$ http://www.citycom.com/ascac/papers/blacknationalist.html $>$ (Friday, January 11, 2002)

Wright, Lawrence. (1997 [1994]). "One Drop of Blood." Pp. 260-6 in Annual Editions: Race and Ethnic Relations 97/98, edited by John A. Kromkowski. Guilford, CT: Dushkin/McGraw-Hill 


\section{APPENDICES}




\section{APPENDIX A}

Black Any and Black Only proportions by state, ranked from highest to lowest Black Any proportion

\begin{tabular}{|l|c|c|c|c|}
\hline \multicolumn{1}{|c|}{ State or District } & \multicolumn{2}{|c|}{ Black Any } & \multicolumn{2}{c|}{ Black Only } \\
\hline & Rank & Percent & Rank & Percent \\
\cline { 2 - 5 } District of Columbia & 1 & 61.262 & 1 & 60.013 \\
Mississippi & 2 & 36.620 & 2 & 36.342 \\
Louisiana & 3 & 32.856 & 3 & 32.489 \\
South Carolina & 4 & 29.933 & 4 & 29.542 \\
Georgia & 5 & 29.236 & 5 & 28.700 \\
Maryland & 6 & 28.793 & 6 & 27.894 \\
Alabama & 7 & 26.287 & 7 & 25.993 \\
North Carolina & 8 & 22.068 & 8 & 21.586 \\
Virginia & 9 & 20.360 & 9 & 19.641 \\
Delaware & 10 & 20.055 & 10 & 19.227 \\
New York & 11 & 17.043 & 12 & 15.885 \\
Tennessee & 12 & 16.757 & 11 & 16.396 \\
Arkansas & 13 & 15.978 & 13 & 15.671 \\
Illinois & 14 & 15.602 & 14 & 15.112 \\
Florida & 15 & 15.465 & 15 & 14.613 \\
Michigan & 16 & 14.837 & 16 & 14.215 \\
New Jersey & 17 & 14.401 & 17 & 13.570 \\
Ohio & 18 & 12.089 & 19 & 11.462 \\
Texas & 19 & 11.956 & 18 & 11.532 \\
Missouri & 20 & 11.713 & 20 & 11.249 \\
Pennsylvania & 21 & 10.497 & 21 & 9.972 \\
Connecticut & 22 & 9.957 & 22 & 9.098 \\
Indiana & 23 & 8.848 & 23 & 8.388 \\
Oklahoma & 24 & 8.253 & 24 & 7.563 \\
Kentucky & 25 & 7.716 & 25 & 7.323 \\
Nevada & 26 & 7.532 & 26 & 6.780 \\
\hline
\end{tabular}

Source: U.S. Census 


\section{APPENDIX A (cont.)}

Black Any and Black Only proportions by state, ranked from highest to lowest Black Any proportion

\begin{tabular}{|l|c|r|c|r|}
\hline \multicolumn{1}{|c|}{ State or District } & \multicolumn{2}{c|}{ Black Any } & \multicolumn{2}{c|}{ Black Only } \\
\hline \multirow{3}{*}{ California } & Rank & Percent & Rank & Percent \\
\cline { 2 - 5 } Kansas & 27 & 7.419 & 27 & 6.684 \\
Massachusetts & 28 & 6.346 & 28 & 5.736 \\
Wisconsin & 29 & 6.276 & 30 & 5.409 \\
Rhode Island & 30 & 6.087 & 29 & 5.676 \\
Colorado & 31 & 5.538 & 31 & 4.475 \\
Nebraska & 32 & 4.434 & 33 & 3.838 \\
Alaska & 33 & 4.431 & 32 & 4.005 \\
Minnesota & 34 & 4.330 & 35 & 3.475 \\
Washington & 35 & 4.126 & 34 & 3.491 \\
Arizona & 36 & 4.045 & 36 & 3.228 \\
West Virginia & 37 & 3.617 & 38 & 3.097 \\
Hawaii & 38 & 3.474 & 37 & 3.165 \\
Iowa & 39 & 2.752 & 41 & 1.816 \\
New Mexico & 40 & 2.478 & 39 & 2.114 \\
Oregon & 41 & 2.332 & 40 & 1.888 \\
Utah & 42 & 2.123 & 42 & 1.627 \\
New Hampshire & 43 & 1.092 & 43 & .791 \\
Wyoming & 44 & .989 & 45 & .731 \\
South Dakota & 45 & .985 & 44 & .754 \\
North Dakota & 46 & .886 & 46 & .621 \\
Maine & 47 & .836 & 47 & .610 \\
Vermont & 48 & .749 & 48 & .530 \\
Idaho & 49 & .738 & 49 & .503 \\
Montana & 50 & .628 & 50 & .422 \\
& 51 & .492 & 51 & .298 \\
\hline
\end{tabular}

Source: U.S. Census 


\section{APPENDIX B}

Black Any and Black Only populations by state, ranked from highest to lowest Black Any population

\begin{tabular}{|l|c|r|c|r|}
\hline \multicolumn{1}{|c|}{ State or District } & \multicolumn{2}{|c|}{ Black Any } & \multicolumn{2}{c|}{ Black Only } \\
\hline & Rank & Population & Rank & Population \\
\cline { 2 - 5 } New York & 1 & $3,234,165$ & 1 & $3,014,385$ \\
California & 2 & $2,513,041$ & 5 & $2,263,882$ \\
Texas & 3 & $2,493,057$ & 2 & $2,404,566$ \\
Florida & 4 & $2,471,730$ & 4 & $2,335,505$ \\
Georgia & 5 & $2,393,425$ & 3 & $2,349,542$ \\
Illinois & 6 & $1,937,671$ & 6 & $1,876,857$ \\
North Carolina & 7 & $1,776,283$ & 7 & $1,737,545$ \\
Maryland & 8 & $1,525,036$ & 8 & $1,477,411$ \\
Michigan & 9 & $1,474,613$ & 10 & $1,412,742$ \\
Louisiana & 10 & $1,468,317$ & 9 & $1,451,944$ \\
Virginia & 11 & $1,441,207$ & 11 & $1,390,293$ \\
Ohio & 12 & $1,372,501$ & 12 & $1,301,307$ \\
Pennsylvania & 13 & $1,289,123$ & 13 & $1,224,612$ \\
New Jersey & 14 & $1,211,750$ & 16 & $1,141,821$ \\
South Carolina & 15 & $1,200,901$ & 14 & $1,185,216$ \\
Alabama & 16 & $1,168,998$ & 15 & $1,155,930$ \\
Mississippi & 17 & $1,041,708$ & 17 & $1,033,809$ \\
Tennessee & 18 & 953,349 & 18 & 932,809 \\
Missouri & 19 & 655,377 & 19 & 629,391 \\
Indiana & 20 & 538,015 & 20 & 510,034 \\
Arkansas & 21 & 427,152 & 21 & 418,950 \\
Massachusetts & 22 & 398,479 & 22 & 343,454 \\
D.C. & 23 & 350,455 & 23 & 343,312 \\
Connecticut & 24 & 339,078 & 24 & 309,843 \\
Wisconsin & 25 & 326,506 & 25 & 304,460 \\
Kentucky & 26 & 311,878 & 26 & 295,994 \\
\hline
\end{tabular}

Source: U.S. Census 


\section{APPENDIX B (cont.)}

Black Any and Black Only populations by state, ranked from highest to lowest Black Any population

\begin{tabular}{|l|c|r|c|r|}
\hline \multicolumn{1}{|c|}{ State or District } & \multicolumn{2}{|c|}{ Black Any } & \multicolumn{2}{c|}{ Black Only } \\
\hline & Rank & Population & Rank & Population \\
\cline { 2 - 5 } Oklahoma & 27 & 284,766 & 27 & 260,968 \\
Washington & 28 & 238,398 & 28 & 190,267 \\
Minnesota & 29 & 202,972 & 29 & 171,731 \\
Colorado & 30 & 190,717 & 30 & 165,063 \\
Arizona & 31 & 185,599 & 31 & 158,873 \\
Kansas & 32 & 170,610 & 32 & 154,198 \\
Delaware & 33 & 157,152 & 33 & 150,666 \\
Nevada & 34 & 150,508 & 34 & 135,477 \\
Nebraska & 35 & 75,833 & 35 & 68,541 \\
Oregon & 36 & 72,647 & 38 & 55,662 \\
Iowa & 37 & 72,512 & 36 & 61,853 \\
West Virginia & 38 & 62,817 & 37 & 57,232 \\
Rhode Island & 39 & 58,051 & 39 & 46,908 \\
New Mexico & 40 & 42,412 & 40 & 34,343 \\
Hawaii & 41 & 33,343 & 41 & 22,003 \\
Alaska & 42 & 27,147 & 42 & 21,787 \\
Utah & 43 & 24,382 & 43 & 17,657 \\
New Hampshire & 44 & 12,218 & 44 & 9,035 \\
Maine & 45 & 9,553 & 45 & 6,760 \\
Idaho & 46 & 8,127 & 46 & 5,456 \\
South Dakota & 47 & 6,687 & 47 & 4,685 \\
North Dakota & 48 & 5,372 & 48 & 3,916 \\
Wyoming & 49 & 4,863 & 49 & 3,722 \\
Vermont & 50 & 4,492 & 50 & 3,063 \\
Montana & 51 & 4,441 & 51 & 2,692 \\
\hline
\end{tabular}

Source: U.S. Census 


\section{APPENDIX C}

Number of Black immigrants necessary

to achieve a voting majority, accounting for Black Any, Black Only, Over 18, and Eligible Voters

\begin{tabular}{|l|r|r|r|r|}
\hline STATE & Black Any & Black Only & Over $18^{\mathrm{a}}$ & \multicolumn{1}{|c|}{ Eligible $^{\mathrm{b}}$} \\
\hline Delaware & 469,296 & 482,268 & 336,000 & 332,900 \\
Wyoming & 484,056 & 486,338 & 333,000 & 319,700 \\
Alaska & 572,638 & 583,358 & 380,000 & 376,100 \\
Vermont & 599,843 & 602,701 & 430,000 & 434,000 \\
North Dakota & 631,456 & 634,368 & 452,000 & 455,300 \\
South Dakota & 741,470 & 745,474 & 523,000 & 521,100 \\
Mississippi & 761,242 & 777,040 & 618,000 & 635,800 \\
Montana & 893,313 & 896,811 & 645,000 & 642,900 \\
Rhode Island & 932,217 & 954,503 & 616,000 & 607,700 \\
Hawaii & $1,144,851$ & $1,167,531$ & 752,000 & 749,200 \\
New Hampshire & $1,211,350$ & $1,217,716$ & 845,000 & 843,100 \\
Maine & $1,255,817$ & $1,261,403$ & 924,000 & 924,000 \\
Idaho & $1,277,699$ & $1,283,041$ & 827,000 & 823,400 \\
Louisiana & $1,532,342$ & $1,565,088$ & $1,129,000$ & $1,141,400$ \\
Nebraska & $1,559,597$ & $1,574,181$ & $1,093,000$ & $1,085,300$ \\
South Carolina & $1,610,210$ & $1,641,580$ & $1,311,000$ & $1,314,900$ \\
West Virginia & $1,682,710$ & $1,693,880$ & $1,355,000$ & $1,350,100$ \\
Nevada & $1,697,241$ & $1,727,303$ & 992,000 & 983,200 \\
New Mexico & $1,734,222$ & $1,750,360$ & $1,140,000$ & $1,098,500$ \\
Arkansas & $1,819,096$ & $1,835,500$ & $1,199,000$ & $1,193,000$ \\
Alabama & $2,109,104$ & $2,135,240$ & $2,109,104$ & $1,516,900$ \\
Utah & $2,184,405$ & $2,197,855$ & $1,325,000$ & $1,325,000$ \\
Maryland & $2,246,414$ & $2,341,664$ & $1,803,000$ & $1,803,100$ \\
Kansas & $2,347,198$ & $2,380,022$ & $1,617,000$ & $1,614,800$ \\
Connecticut & $2,727,409$ & $2,785,879$ & $1,969,000$ & $1,954,200$ \\
Iowa & $2,781,300$ & $2,802,618$ & $2,021,000$ & $1,988,300$ \\
\hline
\end{tabular}

a: does not account for Black Only/Black Any

$\mathrm{b}$ : excludes persons disenfranchised as a result of a felony conviction

Source: U.S. Census; The Sentencing Project 


\section{APPENDIX C (cont.)}

Number of Black immigrants necessary

to achieve a voting majority, accounting for

Black Any, Black Only, Over 18, and Eligible Voters

\begin{tabular}{|l|r|r|r|r|}
\hline STATE & Black Any & Black Only & ${\text { Over } 18^{\mathrm{a}}}^{\text {Eligible }^{\mathrm{b}}}$ \\
\hline Oklahoma & $2,881,122$ & $2,928,718$ & $1,964,000$ & $1,946,400$ \\
Oregon & $3,276,105$ & $2,228,000$ & $2,228,000$ & $2,222,500$ \\
Georgia & $3,399,603$ & $3,487,369$ & $1,993,000$ & $1,991,000$ \\
Kentucky & $3,418,013$ & $2,575,000$ & $2,575,000$ & $2,565,000$ \\
Tennessee & $3,782,585$ & $2,780,000$ & $2,780,000$ & $2,758,800$ \\
Colorado & $3,919,827$ & $2,569,000$ & $2,569,000$ & $2,560,300$ \\
Virginia & $4,196,101$ & $2,766,000$ & $2,766,000$ & $2,716,200$ \\
Missouri & $4,284,457$ & $3,209,000$ & $3,209,000$ & $3,190,400$ \\
North Carolina & $4,496,747$ & $2,846,000$ & $2,846,000$ & $2,843,100$ \\
Minnesota & $4,513,535$ & $3,250,000$ & $3,250,000$ & $3,208,400$ \\
Wisconsin & $4,710,663$ & $3,373,000$ & $3,373,000$ & $3,354,300$ \\
Arizona & $4,759,434$ & $2,735,000$ & $2,735,000$ & $2,673,600$ \\
Indiana & $5,004,455$ & $3,692,000$ & $3,692,000$ & $3,688,800$ \\
Washington & $5,417,325$ & $3,733,000$ & $3,733,000$ & $3,614,900$ \\
Massachusetts & $5,552,139$ & $3,898,000$ & $3,898,000$ & $3,898,000$ \\
New Jersey & $5,990,850$ & $3,861,000$ & $3,861,000$ & $3,853,100$ \\
Michigan & $6,989,218$ & $7,112,960$ & $5,071,000$ & $5,074,100$ \\
Illinois & $8,543,951$ & $8,665,579$ & $5,687,000$ & $5,696,300$ \\
Ohio & $8,608,138$ & $8,750,526$ & $6,515,000$ & $6,516,400$ \\
Pennsylvania & $9,702,808$ & $7,184,000$ & $7,184,000$ & $7,187,300$ \\
Florida & $11,038,918$ & $11,311,368$ & $7,677,000$ & $7,439,100$ \\
New York & $12,508,127$ & $12,947,687$ & $8,215,000$ & $8,213,600$ \\
Texas & $15,865,706$ & $16,042,688$ & $9,410,000$ & $9,113,200$ \\
California & $28,845,566$ & $29,343,884$ & $16,006,000$ & $15,903,600$ \\
\hline
\end{tabular}

a: does not account for Black Only/Black Any

b: excludes persons disenfranchised as a result of a felony conviction

Source: U.S. Census; The Sentencing Project 